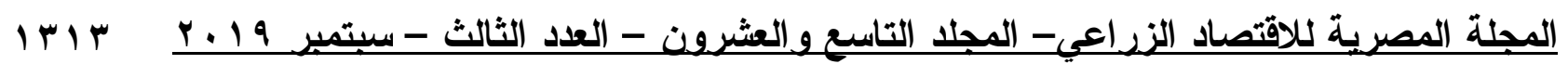

دراسة اقتصادية لأثر السياسات الزراعية على محصول القمح في مصر

\author{
د/ رشا صالح منصور \\ باحث - معهز بحوث الاقتصاد الزراعي منصور
}

مقدمة:

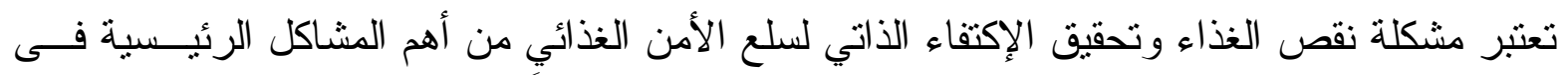

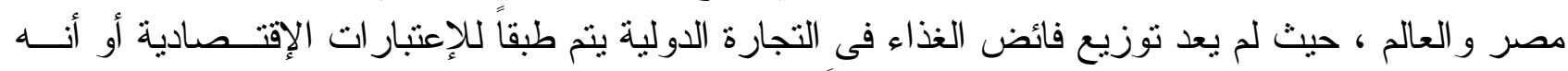

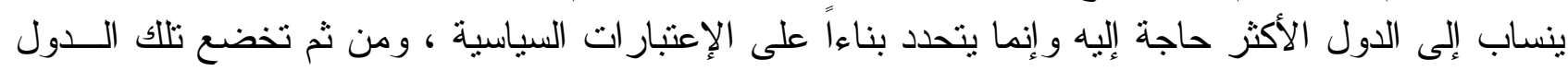

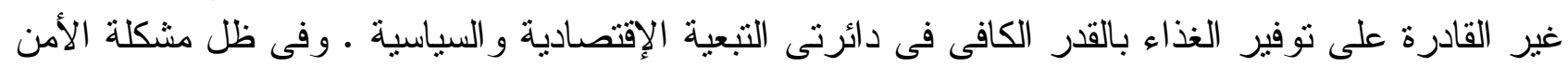

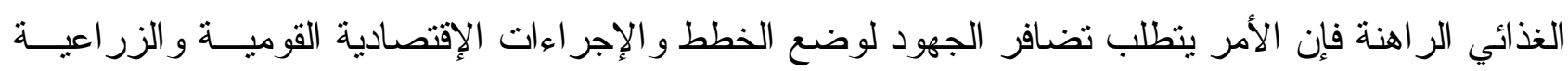

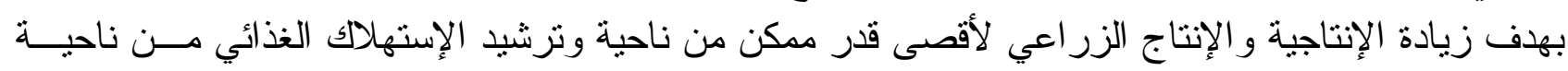

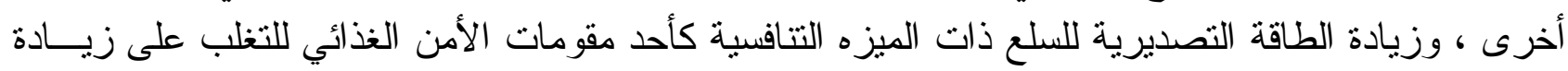

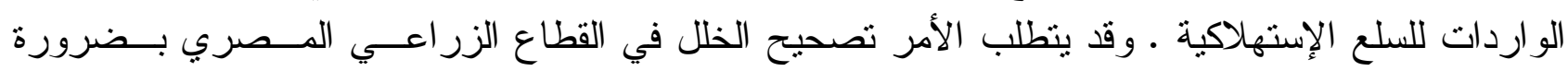

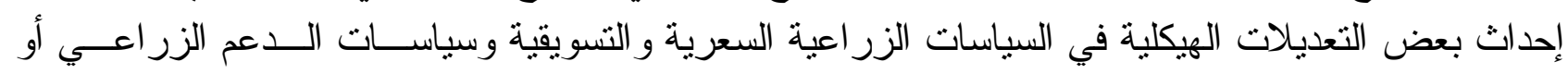

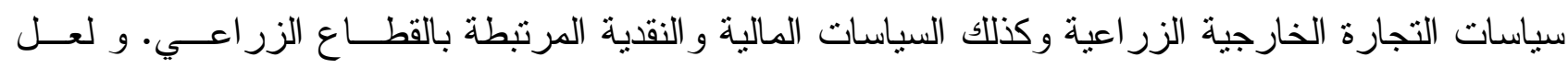
زيادة الفجوة الغذائية المصرية وإرتباطها بالإختلالات الهيكلية للموارد الإقتصادية وزيادة معدل النمو السكانى

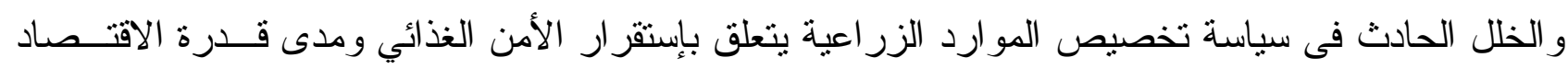

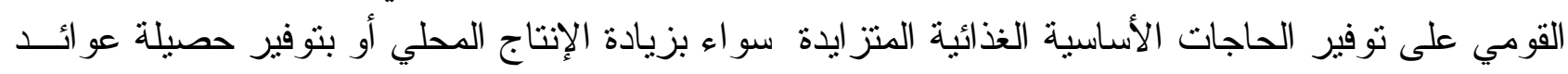

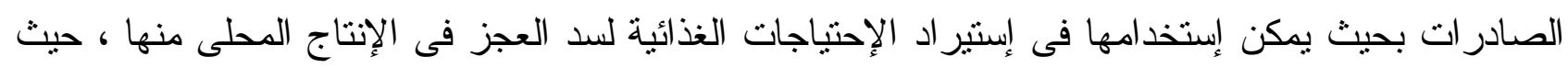

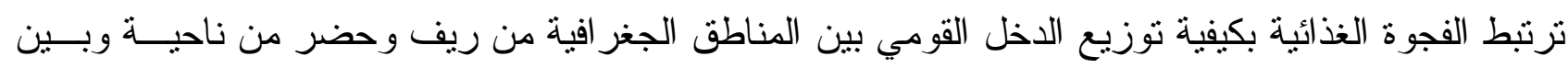

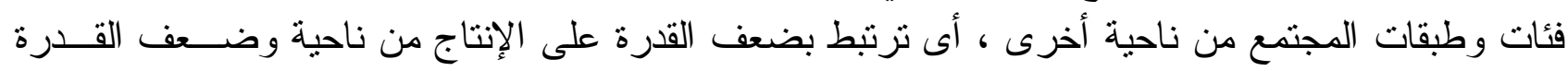

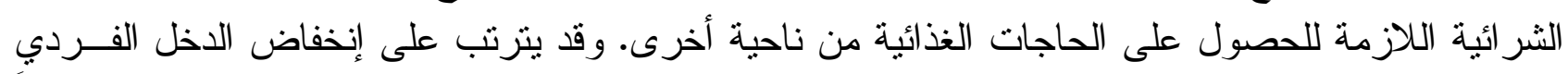
النقدي إنخفاض أكبر فى إستهلاك السلع الغذائية حيث تصبح مرونة الطلب الدخلية على الغذاء منخفضة نسبياً

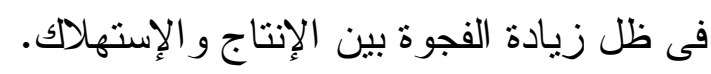

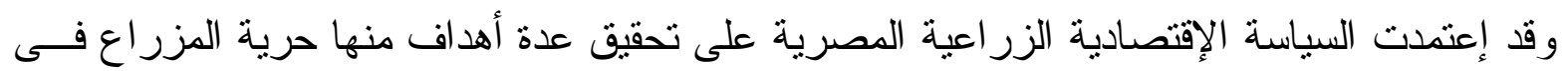

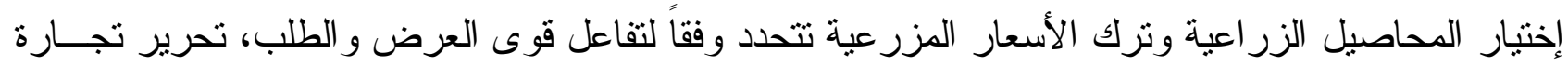

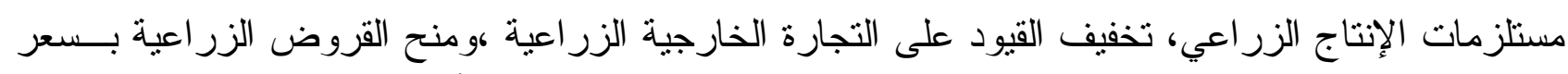

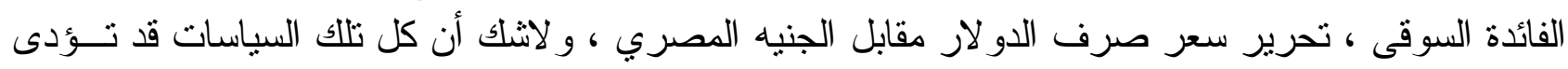

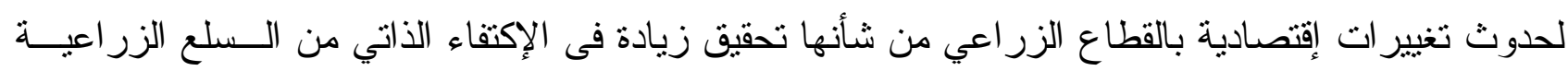

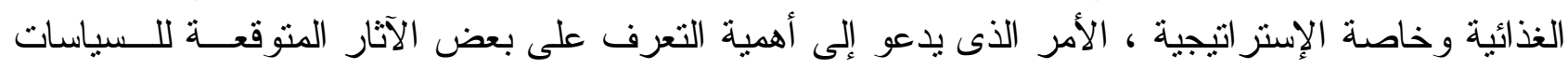

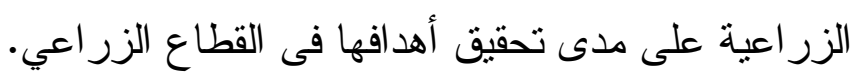

المشكلة البحثية:

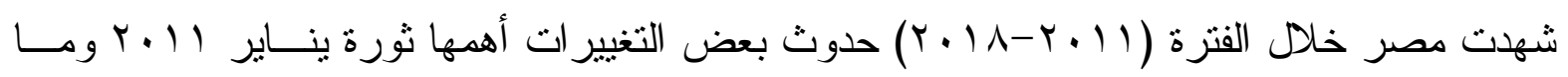
تبعها من سياسات زر اعية وسياسات تحرير سعر الصرف ، مما إنعكس بدوره على تكلفة مستلزمات الإنتـاج

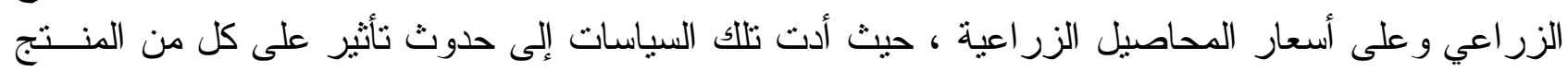

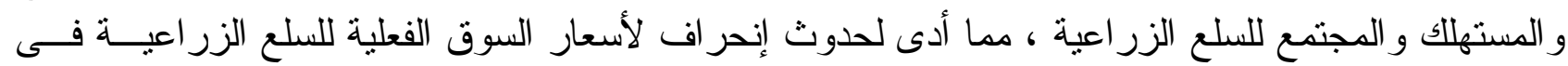

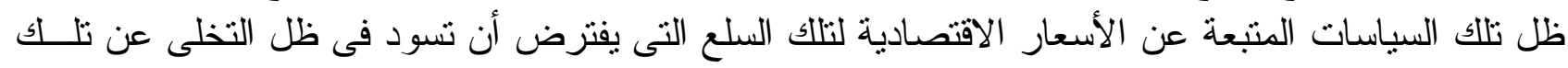

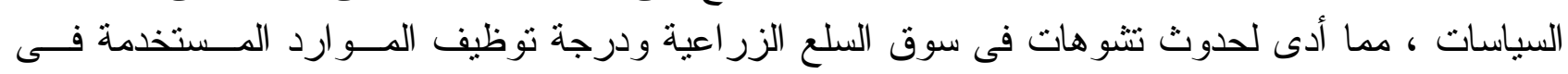




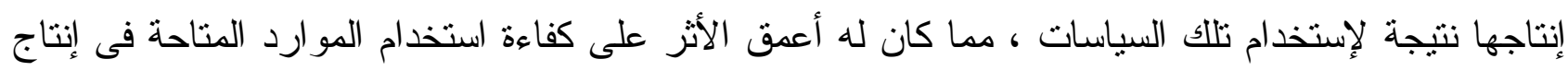

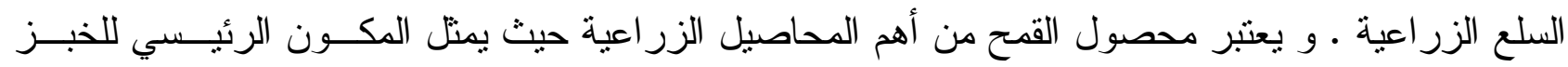

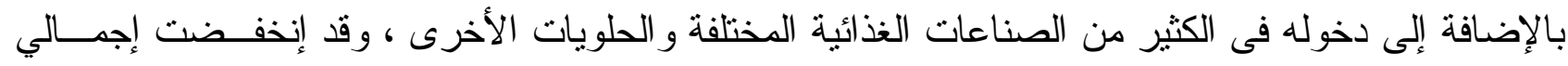

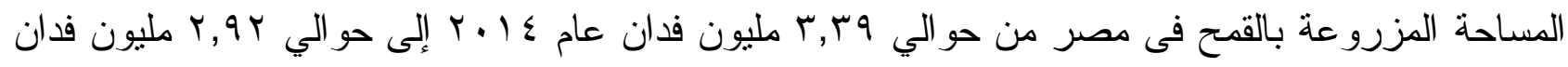

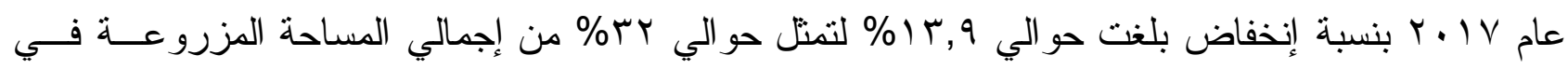

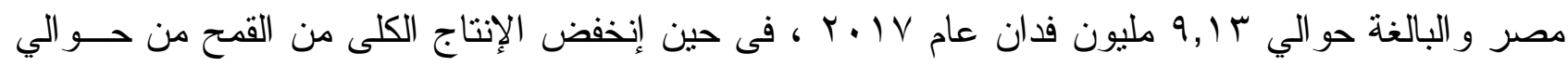

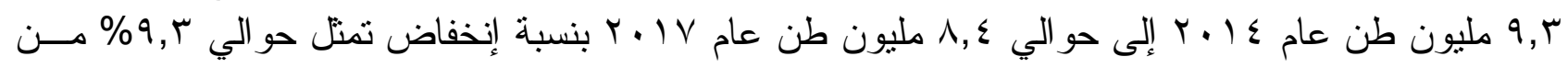

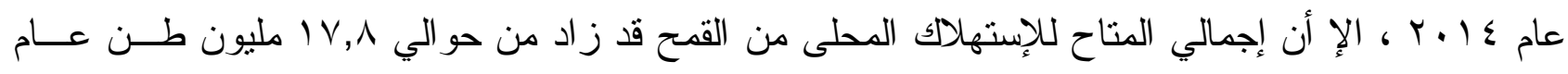

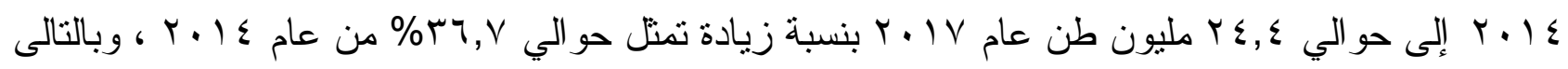

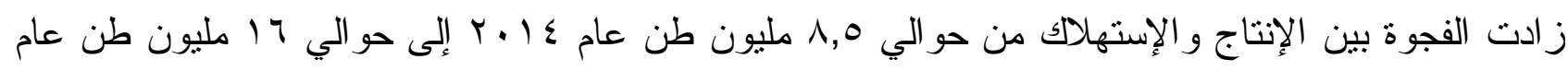

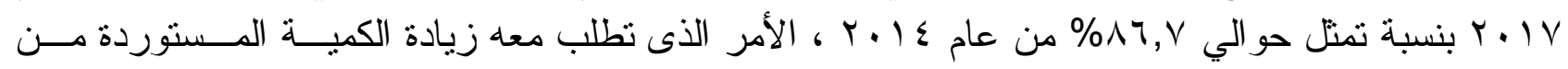

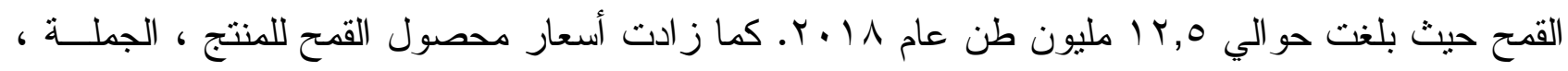

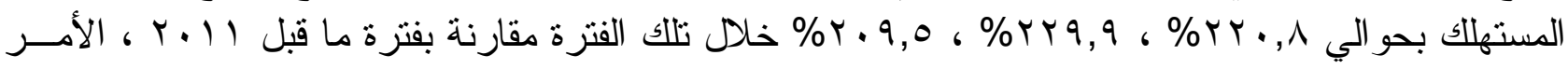

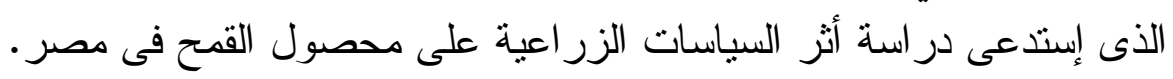
الأهداف البحثية:

تستهدف هذه الدراسة قياس أثز السياسات الزر اعية على كفاءة إستخدام الــــوارد لتحقيــق الأهــن

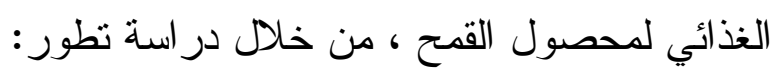

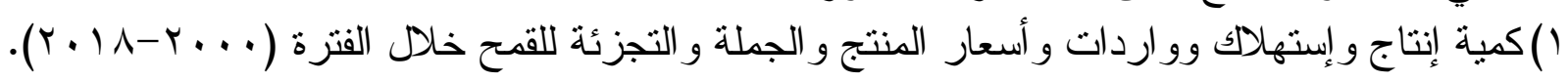

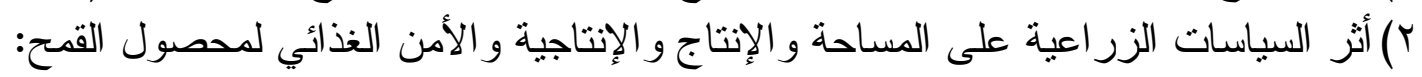

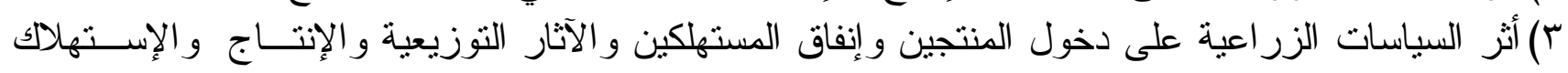

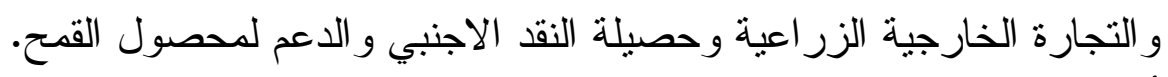

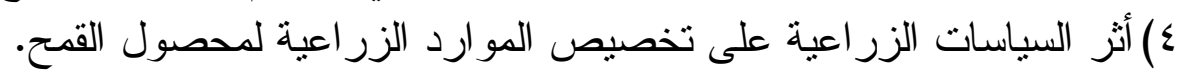

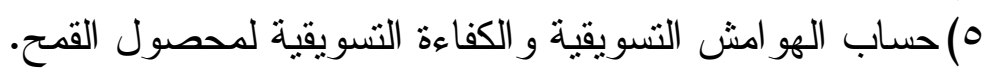

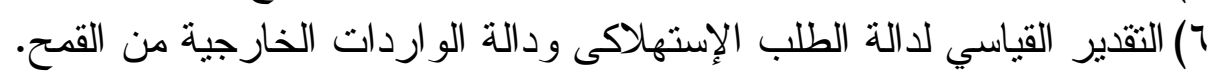

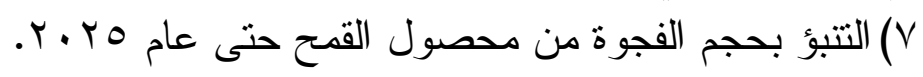

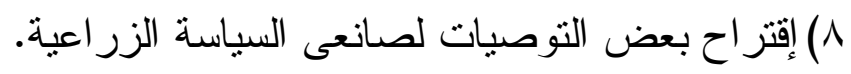
الأسلوب البحثي ومصادر البيانات:

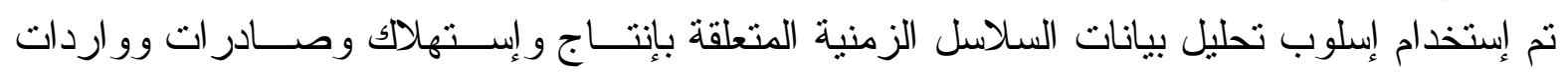

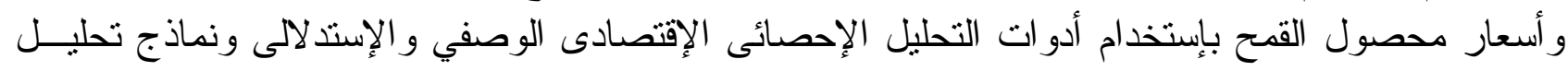

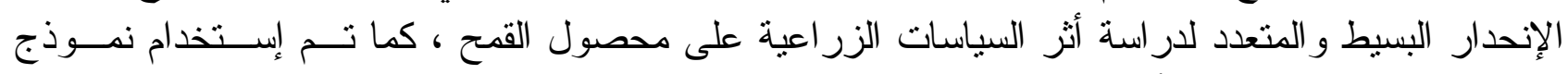

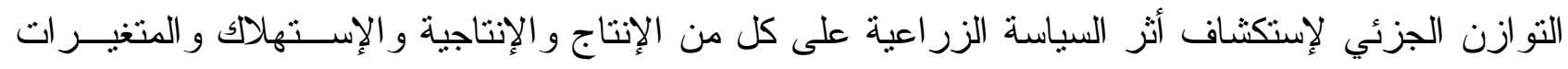

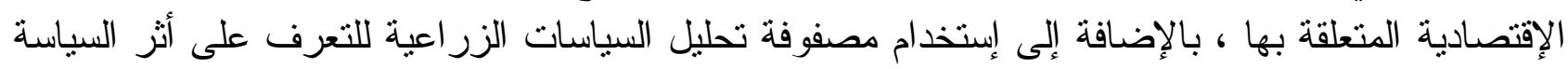

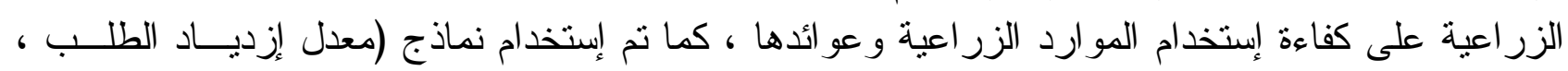

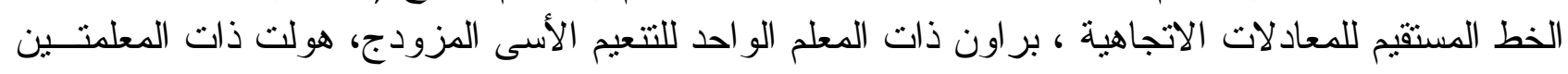

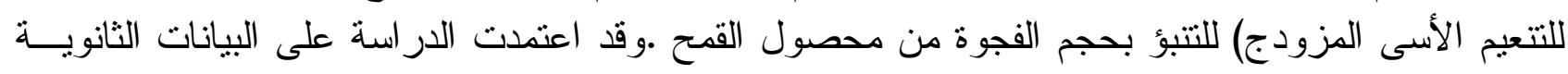

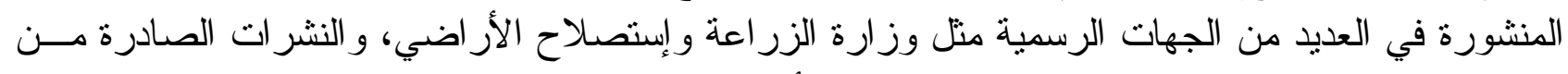

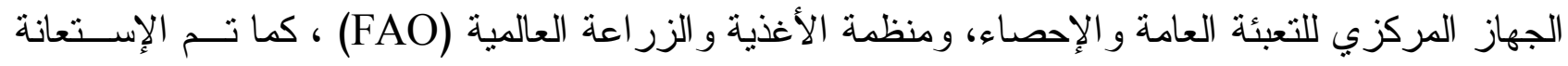

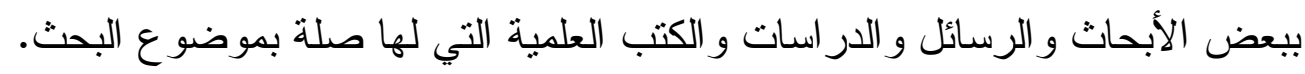




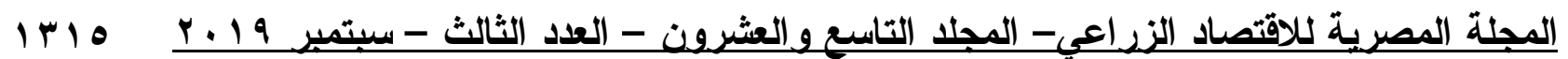

مناقشة النتائج

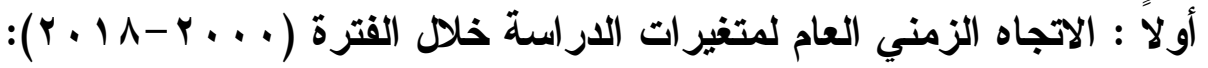

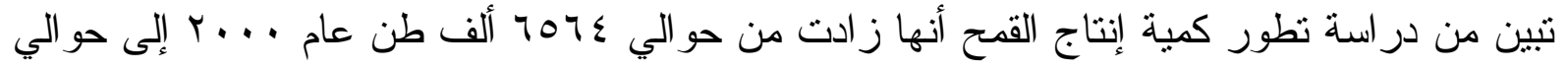

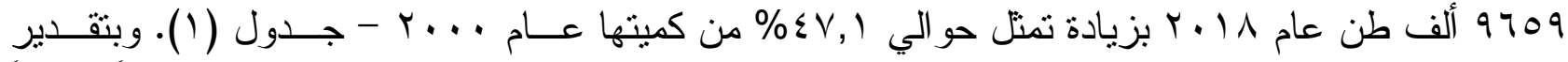

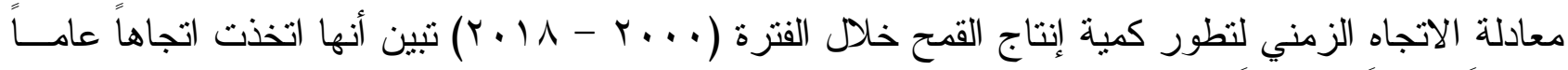

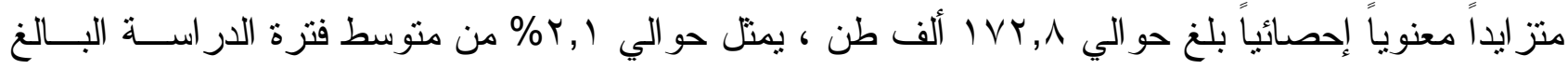

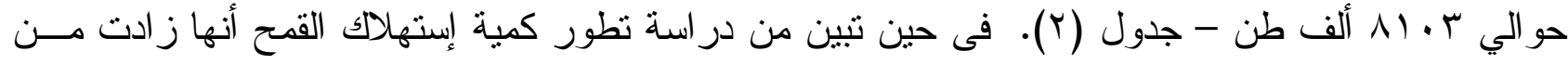

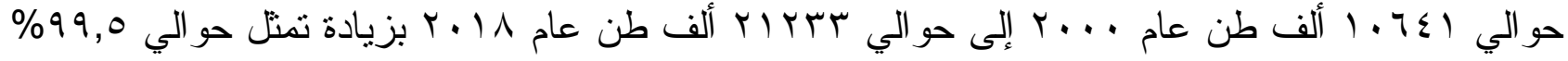

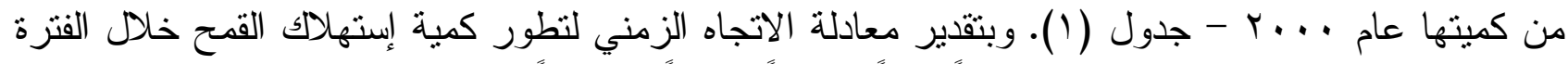

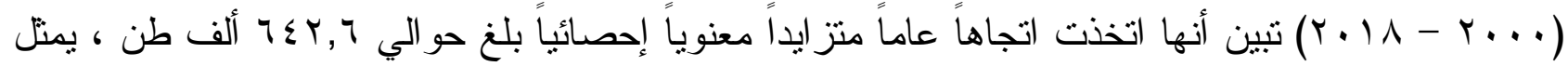

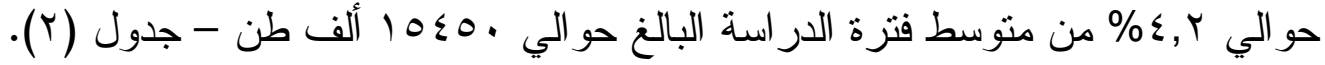

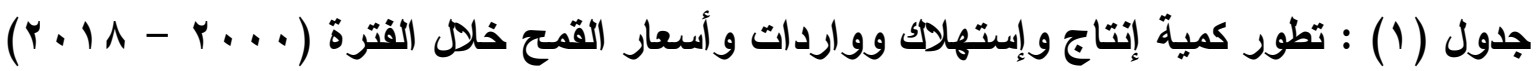
(الكمية : ألف طن - السعر :جنيه/طن)

\begin{tabular}{|c|c|c|c|c|c|c|}
\hline سعر المستهبلك & سعر الجملة & سعر المنتج & كمية الو اردات & المتاح للاستئهلاك & الإتتاج & السنة \\
\hline 1120 & 728 & 695 & 4896 & 10641 & 6564 & 2000 \\
\hline 1120 & 734 & 701 & 4413 & 10508 & 6355 & 2001 \\
\hline 1170 & 799 & 718 & 5575 & 12422 & 6625 & 2002 \\
\hline 1270 & 987 & 859 & 4057 & 10958 & 6845 & 2003 \\
\hline 1660 & 1229 & 1000 & 4363 & 11748 & 7178 & 2004 \\
\hline 1440 & 1267 & 1120 & 5688 & 13310 & 8141 & 2005 \\
\hline 1490 & 1292 & 1127 & 5817 & 14288 & 8274 & 2006 \\
\hline 1840 & 1418 & 1153 & 5911 & 13790 & 7379 & 2007 \\
\hline 2050 & 1846 & 1553 & 5205 & 14546 & 7977 & 2008 \\
\hline 2500 & 1785 & 1613 & 4092 & 11450 & 8523 & 2009 \\
\hline 2990 & 1946 & 1813 & 20487 & 17685 & 7169 & 2010 \\
\hline 3470 & 2534 & 2347 & 19578 & 17153 & 8370 & 2011 \\
\hline 3620 & 2724 & 2520 & 13020 & 15782 & 8795 & 2012 \\
\hline 4050 & 2965 & 2580 & 7453 & 16678 & 9460 & 2013 \\
\hline 4340 & 3260 & 2740 & 10871 & 17825 & 9280 & 2014 \\
\hline 4590 & 3510 & 2753 & 10489 & 19563 & 9608 & 2015 \\
\hline 5570 & 4489 & 3673 & 11416 & 19592 & 9343 & 2016 \\
\hline 8140 & 7060 & 6080 & 12025 & 21374 & 8421 & 2017 \\
\hline 8200 & 7118 & 6128 & 11582 & 21233 & 9659 & 2018 \\
\hline 3191 & 2510 & 2167 & 8786 & 15450 & 8103 & المتوسط \\
\hline 1695 & 1276 & 1123 & 6409 & 12850 & 7366 & $\begin{array}{c}\text { متوسط } \\
(2010-2000)\end{array}$ \\
\hline 5248 & 4208 & 3603 & 12054 & 19025 & 9117 & $\begin{array}{c}\text { متوسط } \\
\text { (2018-2011) }\end{array}$ \\
\hline 3552 & 2932 & 2480 & 5645 & 6175 & 1751 & التغير بين الفترتين \\
\hline 209.5 & 229.9 & 220.8 & 88.1 & 48.1 & 23.8 & نسبة التغير \\
\hline
\end{tabular}

المصل : جمعت وحسبت من :

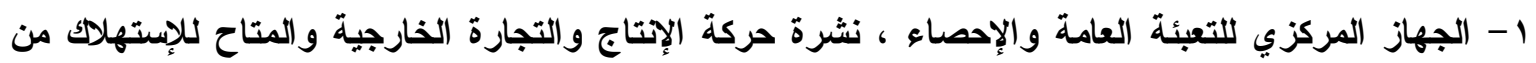
السلع الزراعية ، أعداد متفرقة.

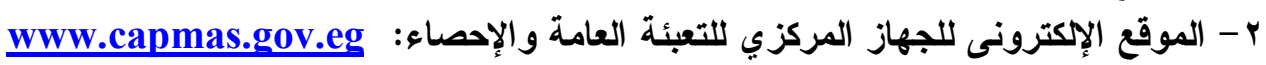

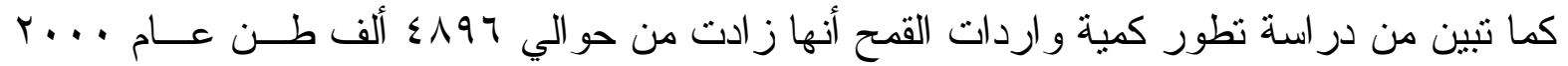

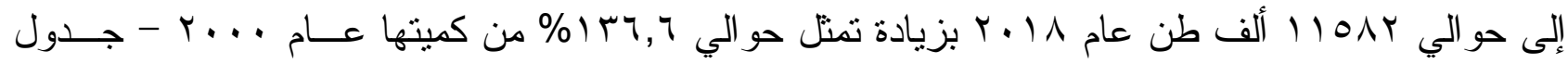

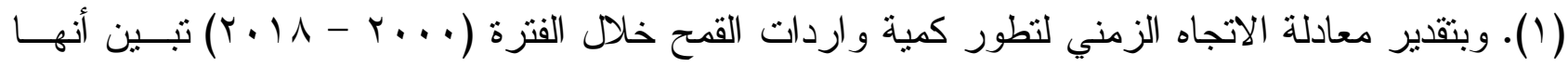




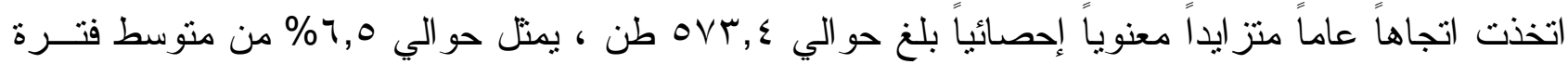

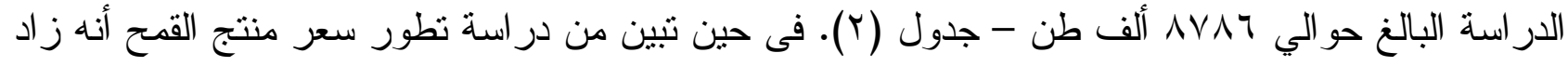

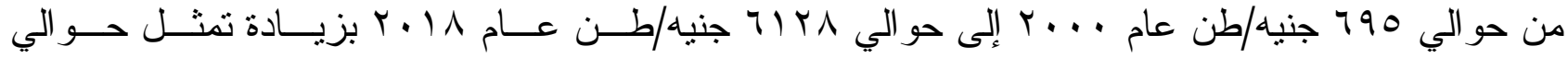

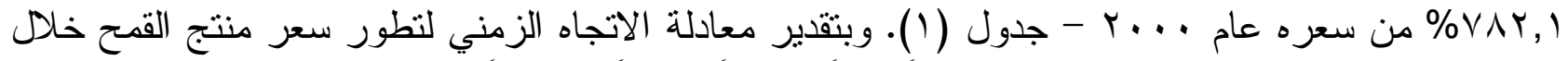

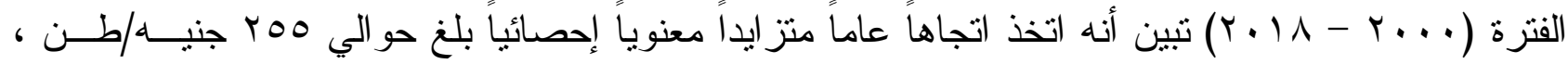

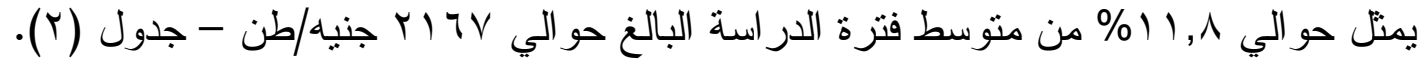

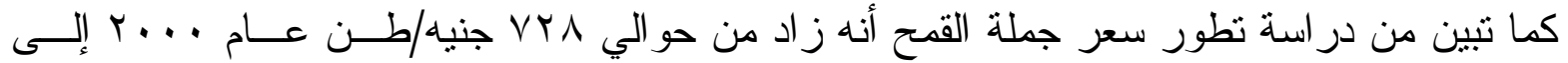

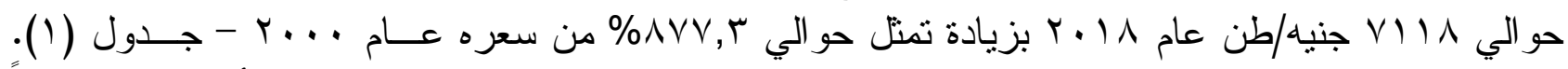

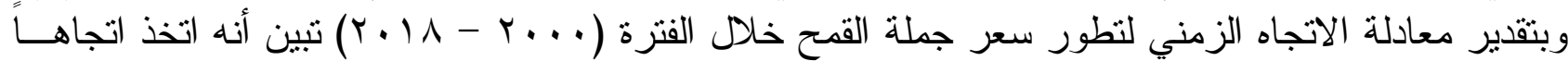

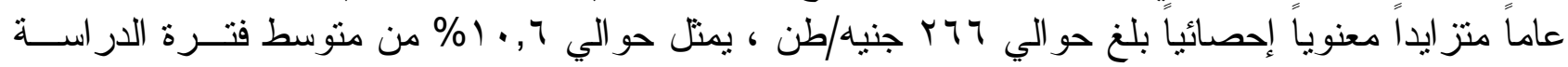

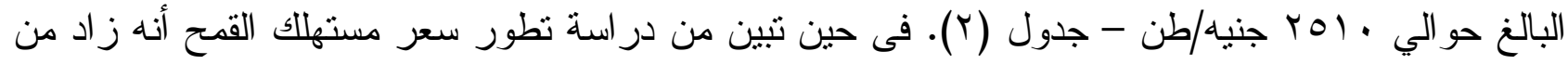

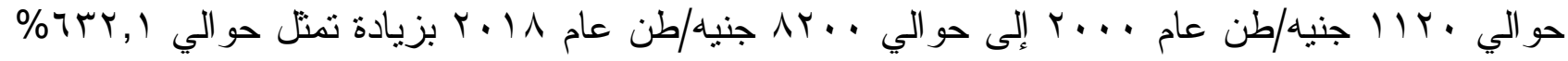

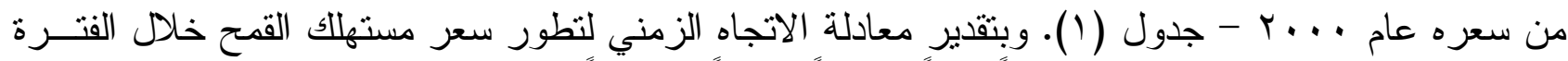

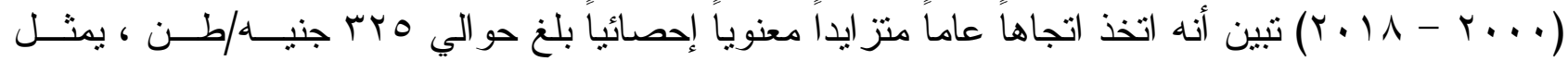

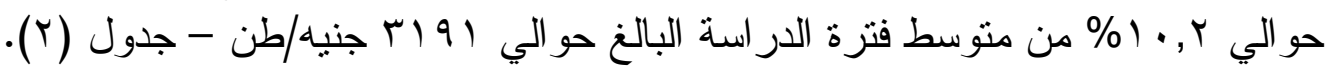

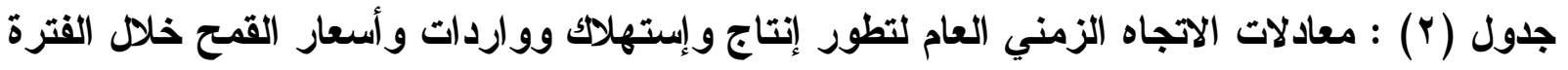
$(r+1 \Lambda-r \ldots)$

\begin{tabular}{|c|c|c|c|c|c|}
\hline $\mathbf{F}$ & $\mathbf{R}^{2}$ & السنوي النمو & السنتوسط & النموذج & المتغير \\
\hline $48.8^{* *}$ & 0.753 & 2.1 & 8103 & $\hat{\mathbf{Y}}_{\mathrm{t}}=6375.2+\underset{(6.99)}{172.8 \mathrm{~T}_{* *}^{\mathrm{T}}}$ & كميَة الإنتاج \\
\hline $74.4^{* *}$ & 0.823 & 4.2 & 15450 & $\begin{array}{r}\hat{\mathbf{Y}}_{\mathrm{t}}=9023.8+642.6 \mathrm{~T} \\
(8.62)\end{array}$ & 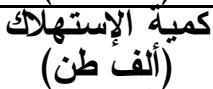 \\
\hline $8.9^{* *}$ & 0.358 & 6.5 & 8786 & $\mathbf{Y}_{\mathrm{t}}=3183.6+\underset{(2.99)}{573.4 \mathrm{~T}_{* *}}$ & كمية (الو اردات \\
\hline $58.8^{* *}$ & 0.776 & 11.8 & 2167 & $\hat{\mathbf{Y}}_{\mathrm{t}}=382.9+255.0 \mathrm{~T}$ & سنية/طنتج) \\
\hline $56.6^{* *}$ & 0.780 & 10.6 & 2510 & $\begin{array}{r}\hat{\mathbf{Y}}_{\mathrm{t}}=273.1+266 \mathrm{~T}_{* *} \\
(7.52)\end{array}$ & 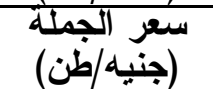 \\
\hline $80.5^{* *}$ & 0.834 & 10.2 & 3191 & $\begin{array}{r}\hat{\mathbf{Y}}_{\mathrm{t}}=174.4+325 \mathrm{~T}_{* *} \\
(8.97)\end{array}$ & 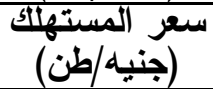 \\
\hline
\end{tabular}

* معنوى عند 0

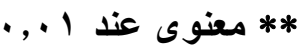

المصلر : جمعت وحسبت من جدول (1) بالار اسة.

ثانياً : أثز السياسات الزراعية على أهم العوامل المرتبطة بالأمن الغذائي لمحصول القمح:

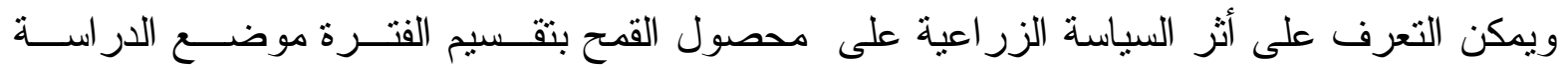

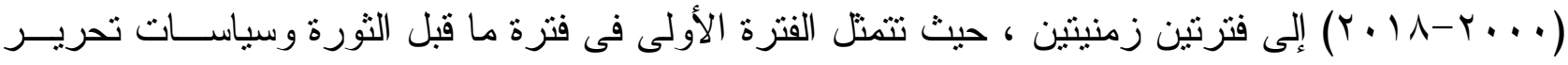

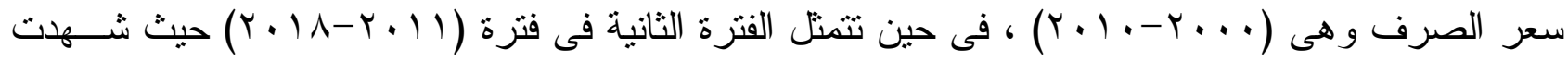

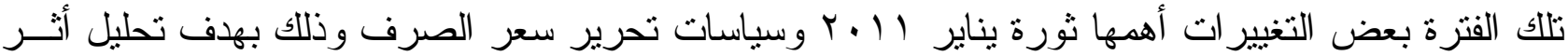

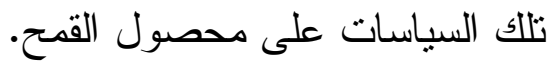

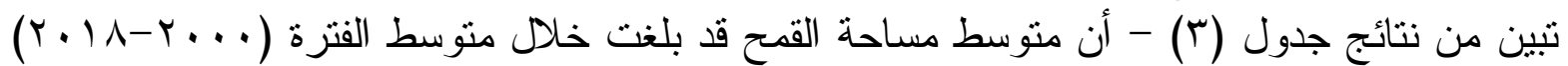

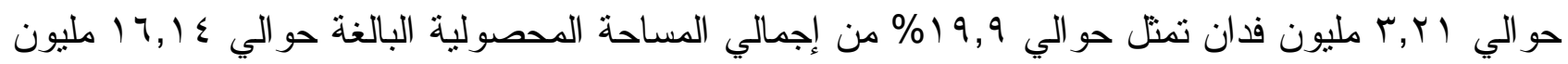

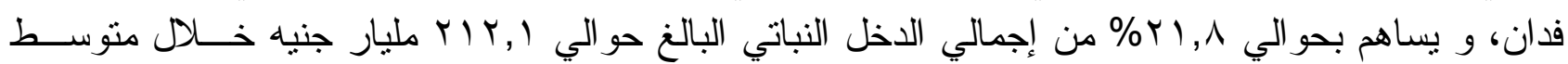

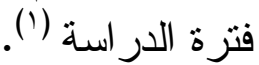




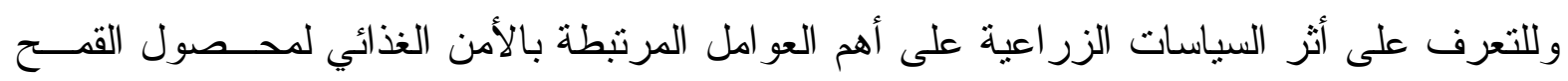

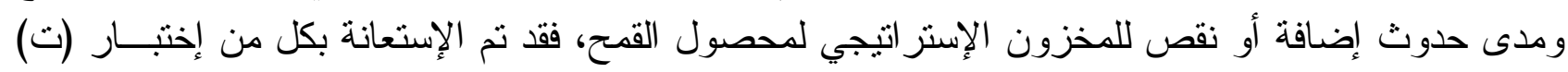

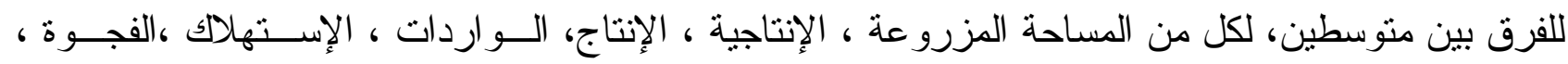

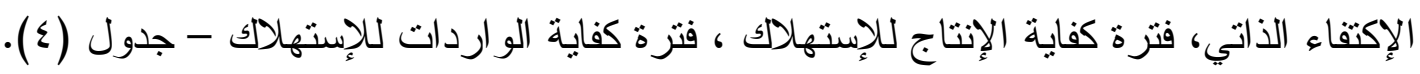

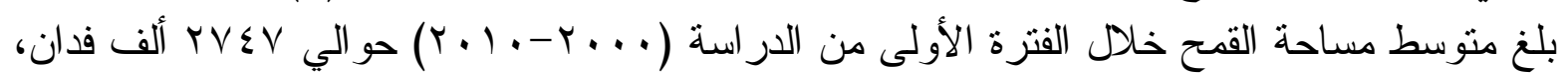

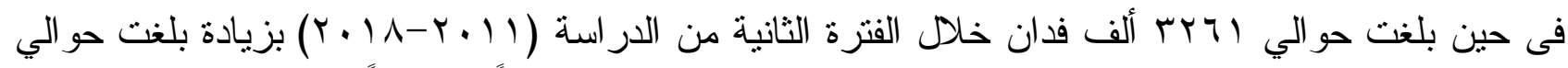

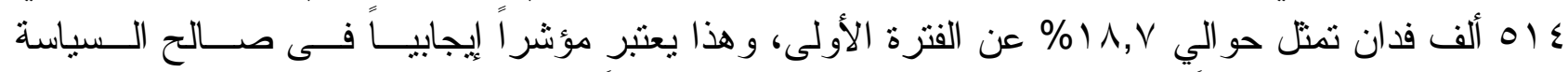

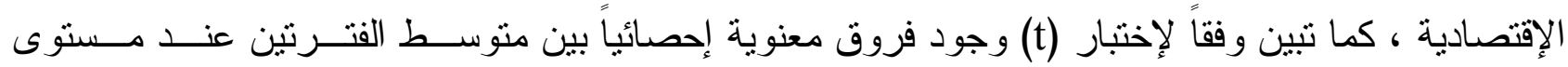

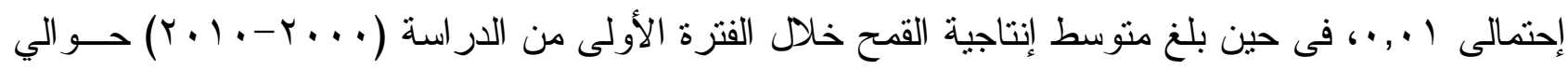

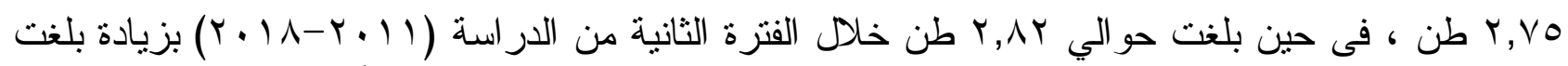

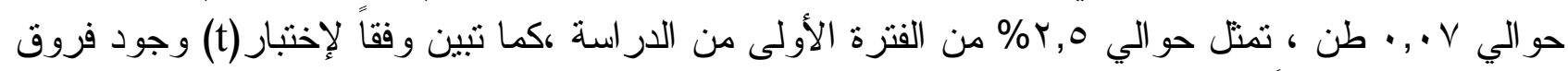

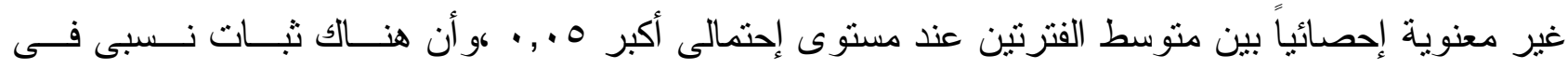

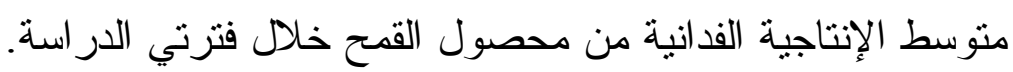

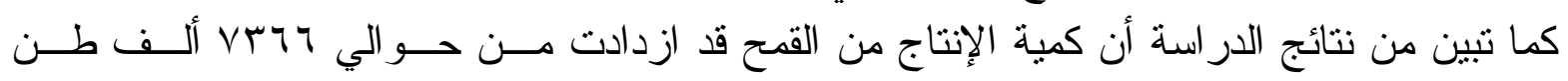

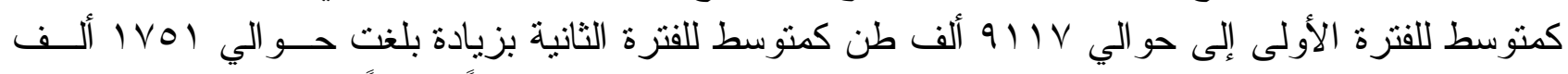

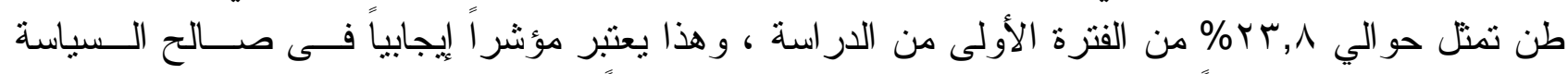

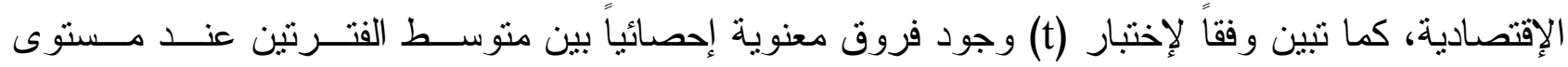

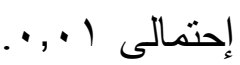

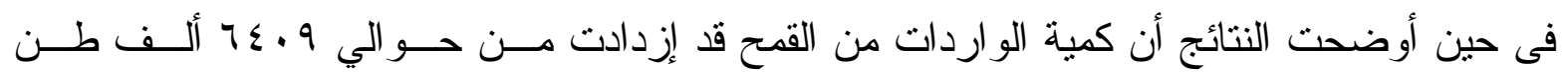

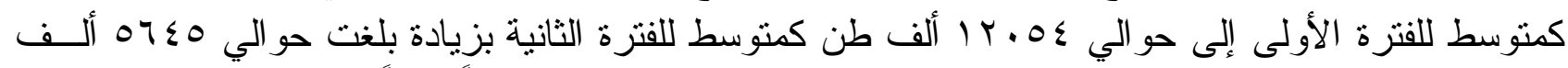

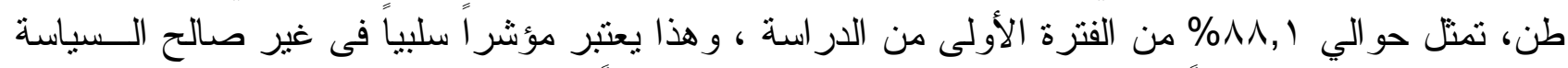

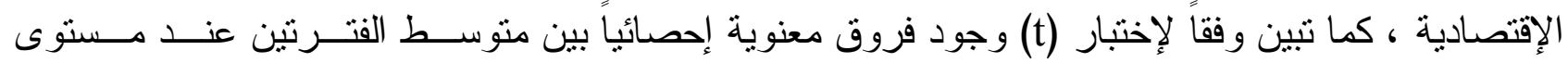

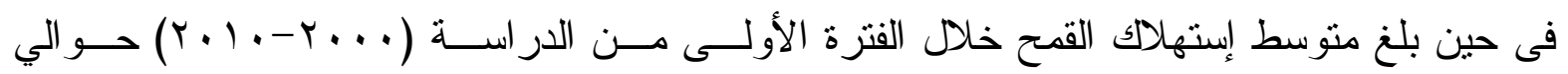

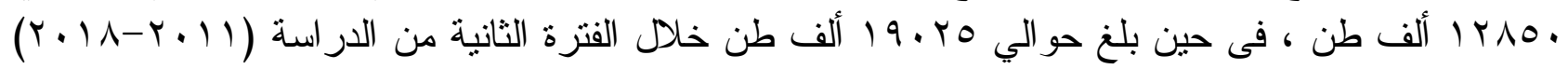

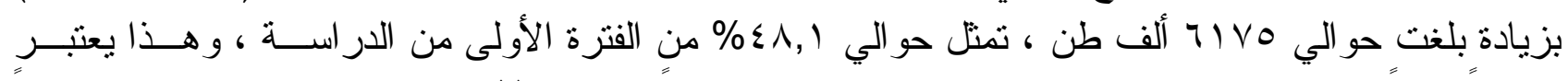

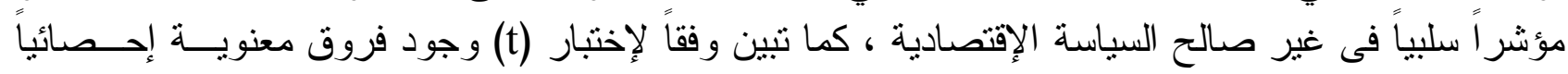

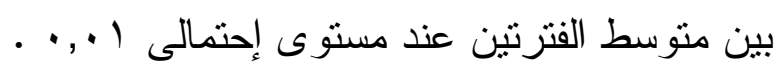

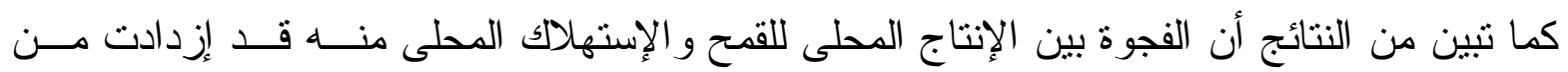

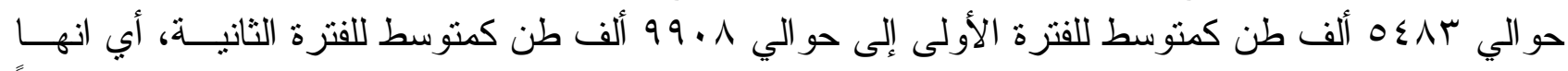

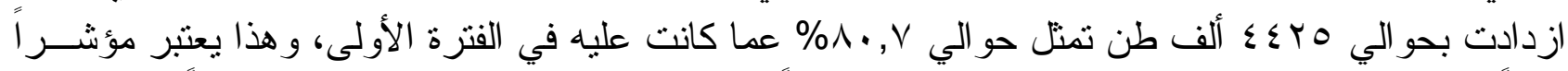

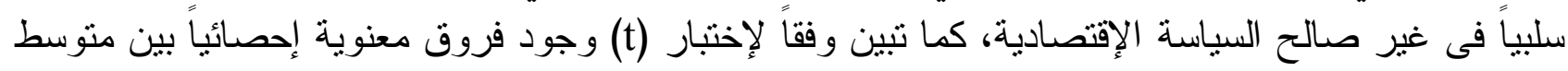

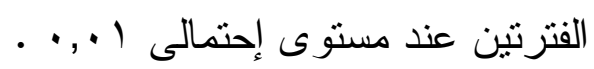

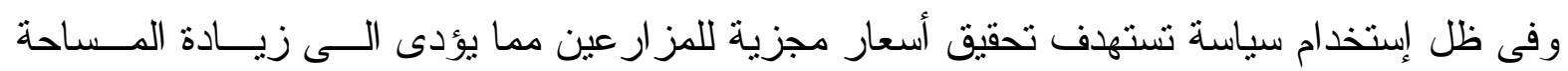

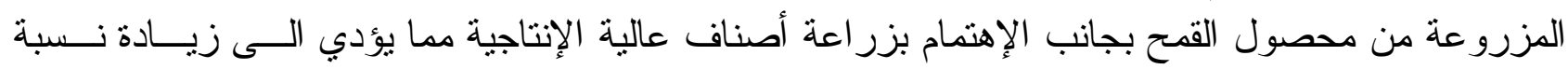

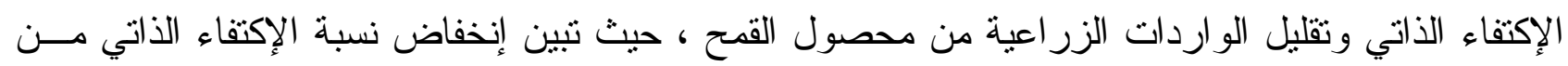

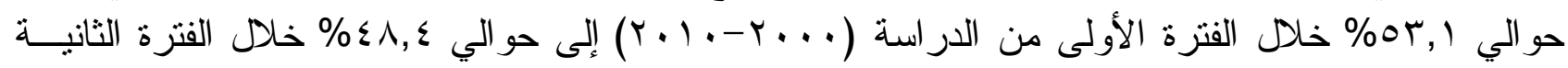




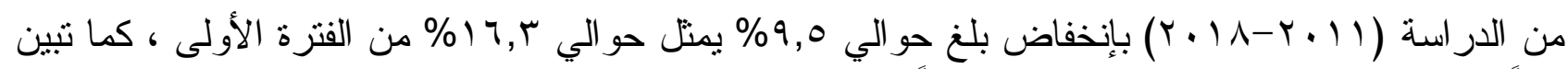

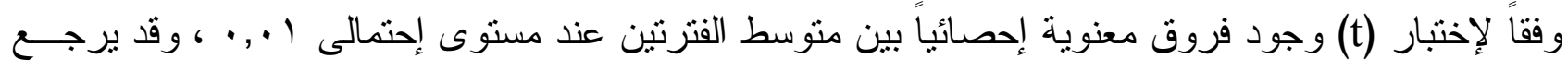

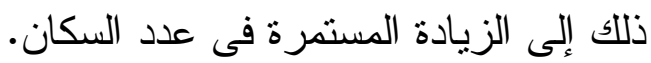

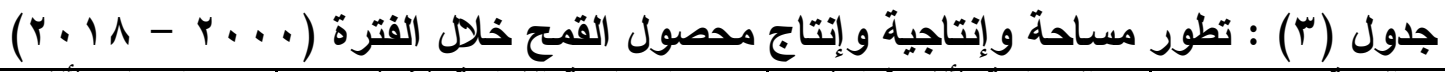

\begin{tabular}{|c|c|c|c|}
\hline الإتتاج (أف طن) & الإلتاجية الفدانية (طن) & المساحة (ألف فران) & ألسنة \\
\hline 6564 & 2.80 & 2463 & 2000 \\
\hline 6355 & 2.76 & 2342 & 2001 \\
\hline 6625 & 2.79 & 2450 & 2002 \\
\hline 6845 & 2.81 & 2506 & 2003 \\
\hline 7178 & 2.84 & 2605 & 2004 \\
\hline 8141 & 2.80 & 2985 & 2005 \\
\hline 8274 & 2.77 & 3064 & 2006 \\
\hline 7379 & 2.78 & 2716 & 2007 \\
\hline 7977 & 2.78 & 2920 & 2008 \\
\hline 8523 & 2.74 & 3147 & 2009 \\
\hline 7169 & 2.43 & 3023 & 2010 \\
\hline 8370 & 2.78 & 3049 & 2011 \\
\hline 8795 & 2.81 & 3161 & 2012 \\
\hline 9460 & 2.84 & 3378 & 2013 \\
\hline 9280 & 2.76 & 3393 & 2014 \\
\hline 9608 & 2.82 & 3469 & 2015 \\
\hline 9343 & 2.81 & 3353 & 2016 \\
\hline 8421 & 2.88 & 2922 & 2017 \\
\hline 9659 & 2.87 & 3366 & 2018 \\
\hline 7366 & 2.75 & 2747 & متوسط (2010-2000) \\
\hline 9117 & 2.82 & 3261 & متوسط (2018-2011) \\
\hline 1751 & $\mathbf{0 . 0 7}$ & 514 & ألتغير بين الفترتين \\
\hline 23.8 & 2.5 & 18.7 & نسبة التغير \\
\hline
\end{tabular}

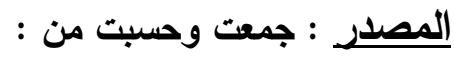

1- الجهاز المركزي للتعبئة العامة والإحصاء ، نشرة حرة حركة الإنتاج والتجارة الخارجية والمتاح للإستهلاك من

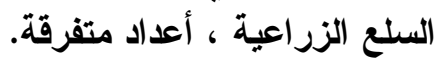

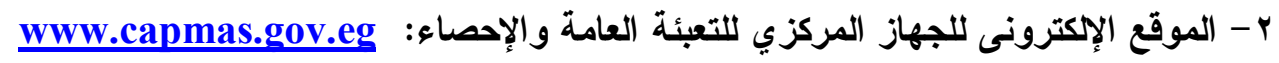

جدول رقم (ع) : نتائج إختبار (t) للفرق بين متوسطين لأهم العوامل المرتبطة بالأمن الغذائي من القمح

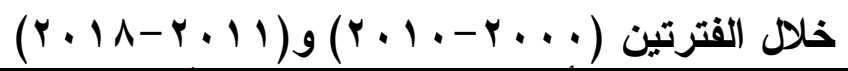

\begin{tabular}{|c|c|c|c|c|c|c|}
\hline الإحتمال & بينة المتوسطين للفرق & المتوسطين & متوسط الفترة ألثانية & متوسط الفترة الأولى & الوحدة & المتغير \\
\hline 0.000 & -4.63 & 514 & 3261 & 2747 & ألف فدان & المساحة \\
\hline 0.09 & -1.83 & 0.07 & 2.82 & 2.75 & طن & الإلتاجية الفدانية \\
\hline 0.000 & $-5.99^{*+1}$ & 1751 & 9117 & 7366 & ألف طن & الإإتاج المحلى \\
\hline 0.000 & -5.20 & 5645 & 12054 & 6409 & ألف طن & الوّاردات \\
\hline 0.008 & $-3.01^{*}$ & 6175 & 19025 & 12850 & ألف طن & الإستهلاك المحلى \\
\hline 0.003 & -3.72 & 4425 & 9908 & 5483 & ألف طن & الفُجـوة \\
\hline 0.015 & 2.73 & -9.5 & 48.8 & 58.3 & $\%$ & نسبة الإكتماء الذاتي \\
\hline 0.014 & $2.73^{* *}$ & -34.9 & 178.0 & 212.9 & يوم & 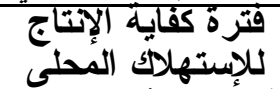 \\
\hline 0.023 & $-1.96^{*}$ & 63.6 & 236.4 & 172.8 & يوم & 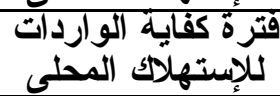 \\
\hline
\end{tabular}

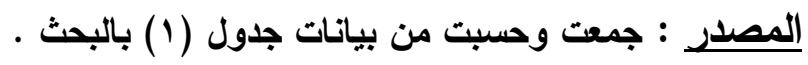




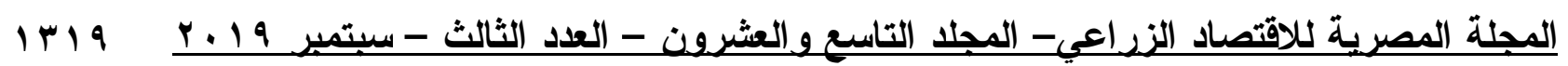

و فيما يتعلق بكفاية كل من الإنتاج و الواردات للإستهلاك المحلى من القمح فقد تبين أن فتــرة كفايـــة

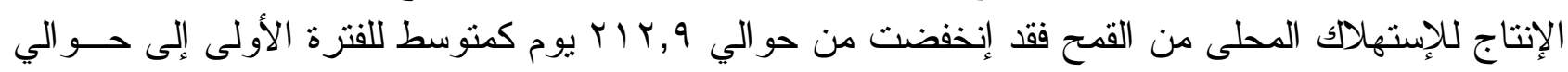

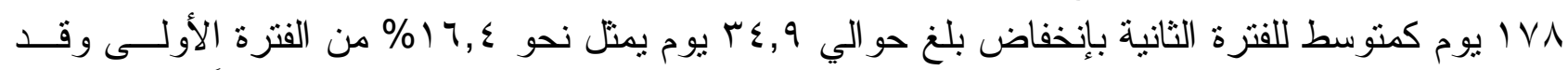

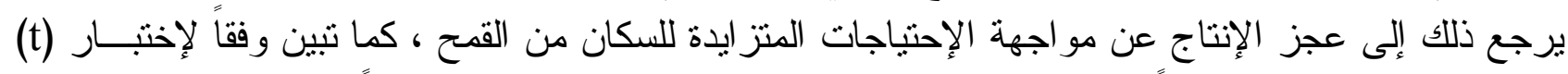

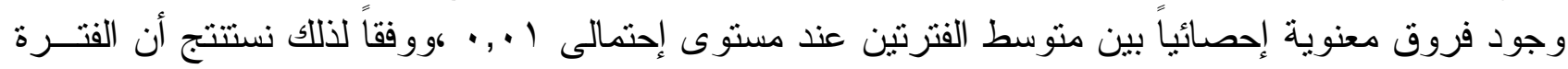

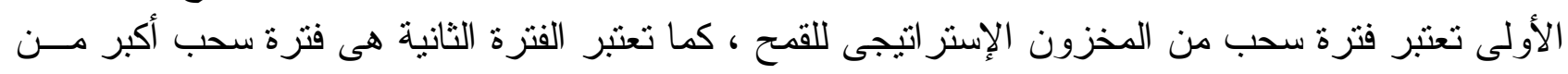

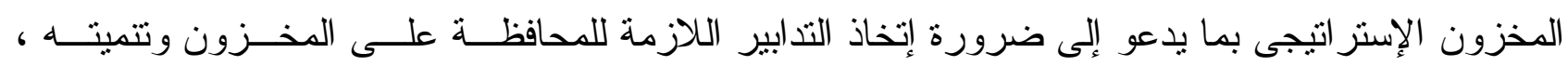

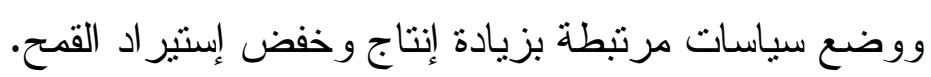

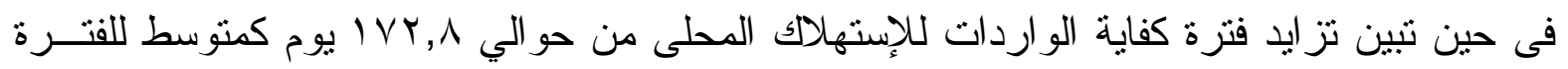

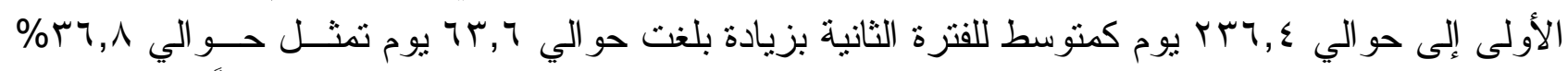

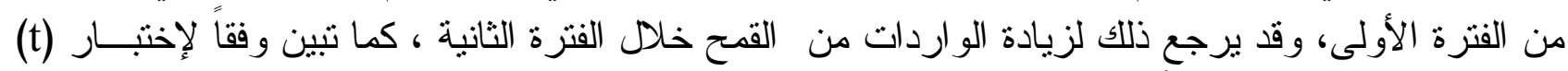
وجود فروق معنوية إحصائياً بين متوسط الفترنين عند مستوى إحتمالى 0 . , . .

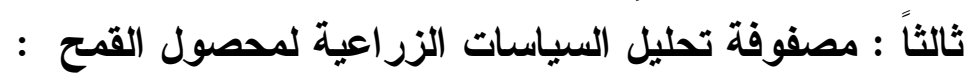

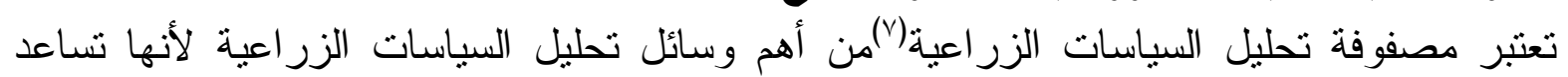

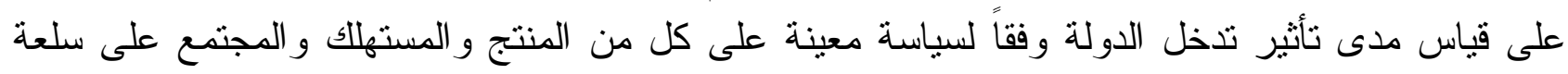
موضع الدر اسة ، كما تستخدم كأداة فعالة من قبل محللى السياسات لقياس مدى إنحر اف أسعار السوق الفعلية

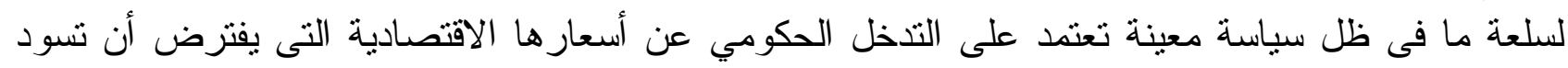

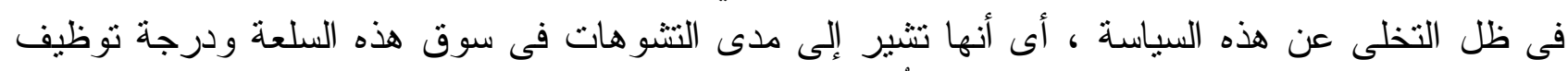

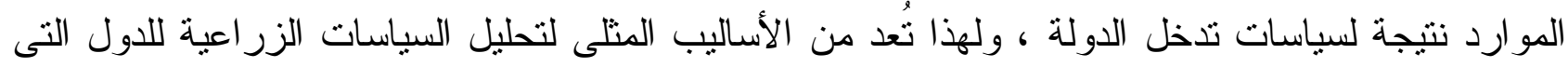
تتسم مو اردها بالندرة النسبية لأنها توضح أثر تلك السياسات على كفاعة استخدام الموارد المتاحة. وتتحدد أهم

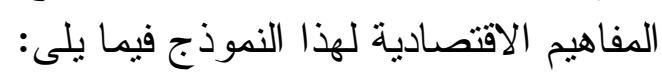
(1) معامل الحماية الأسمية للإنتاج : تعكس قيمة هذا المعامل حجم الدعم الضمنى أى الحماية للمنتج المحلى

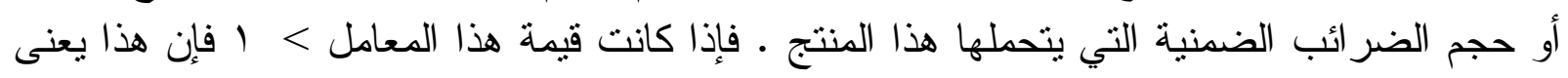

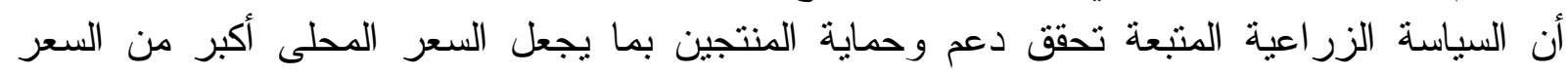

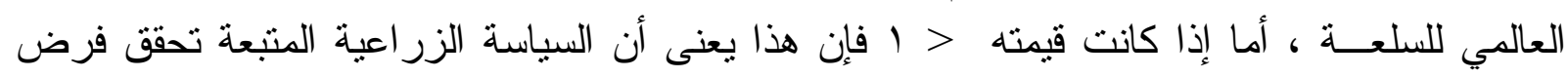

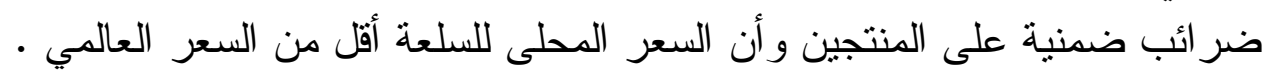

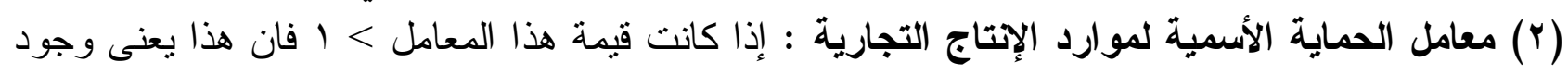

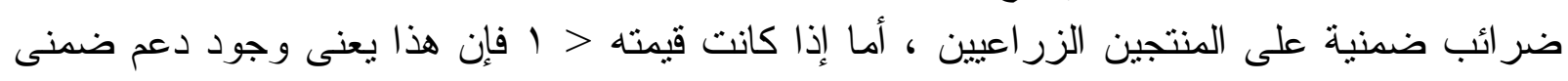
للمنتجين الزر اعيين. (r) معامل الحماية الفعال : تفسير هذا المعامل هو نفس تفسير معامل الحماية الأسمية للإنتاج إلا أنه يأخذ

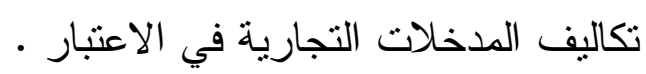

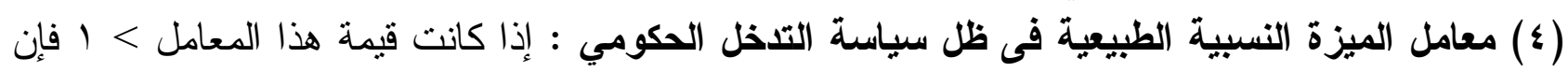

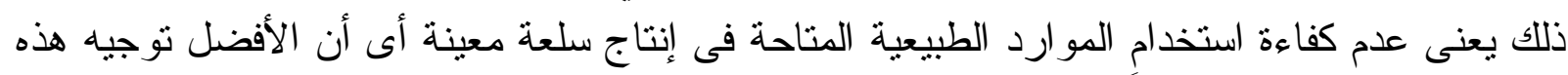

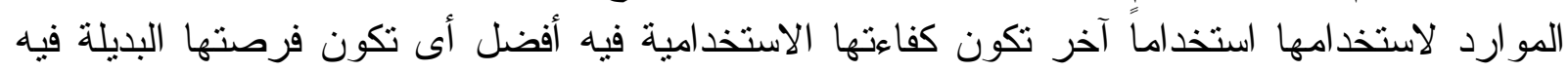

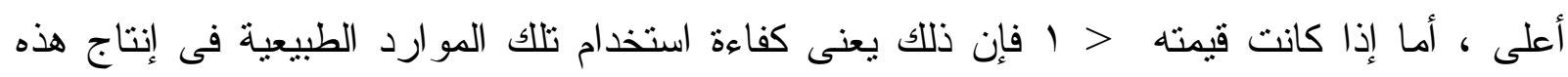
السلعة أى أن فرصنها البديلة أقل . 


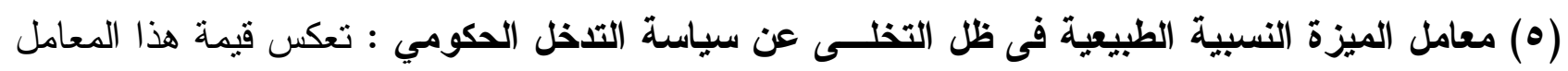

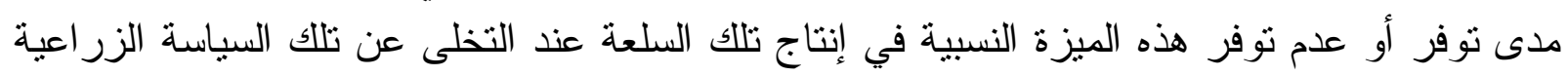

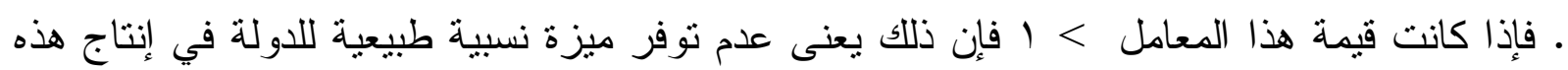

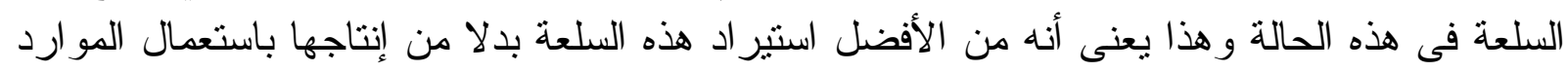

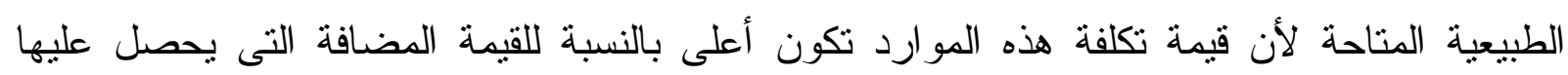

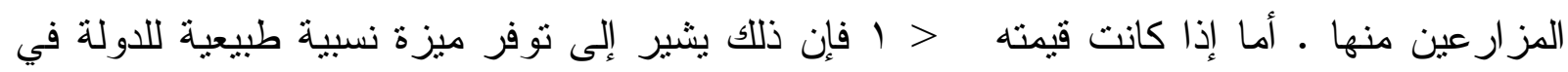

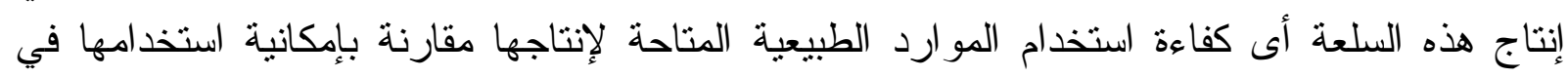

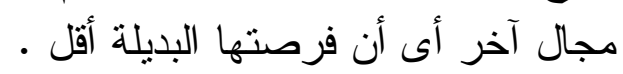

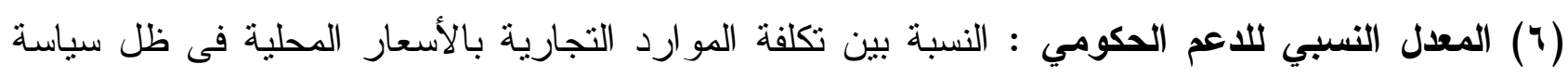

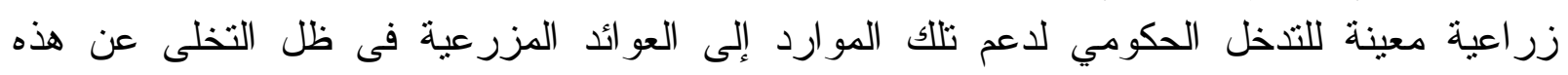

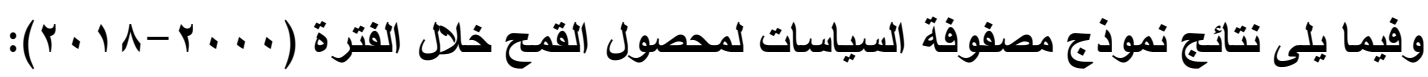

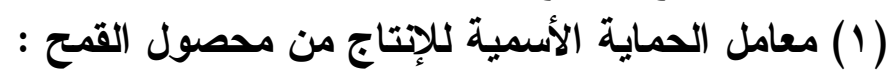

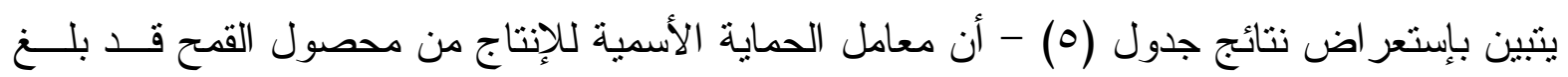

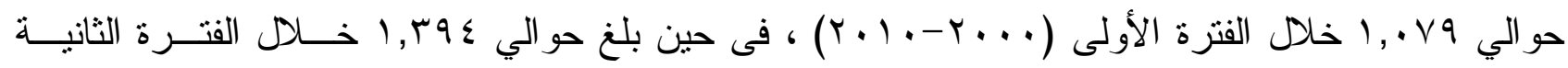

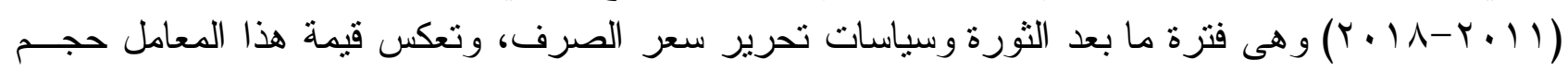

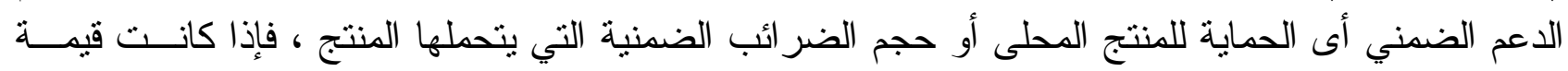

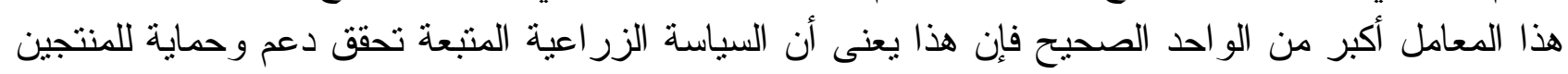

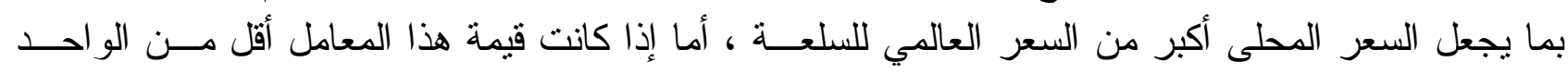

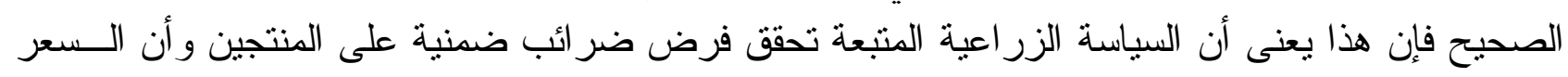

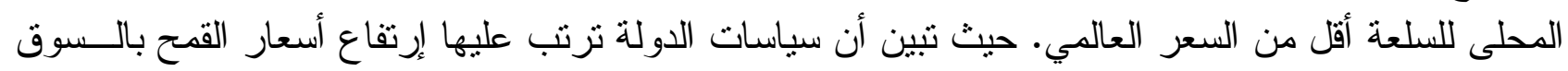

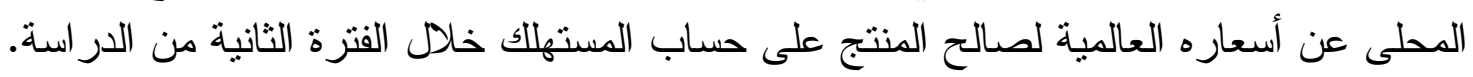

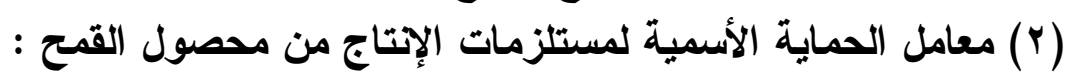

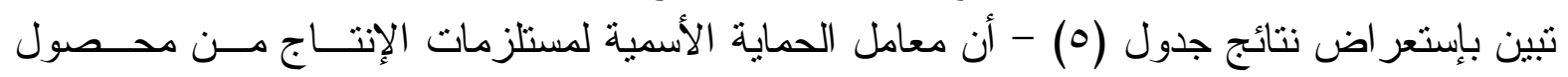

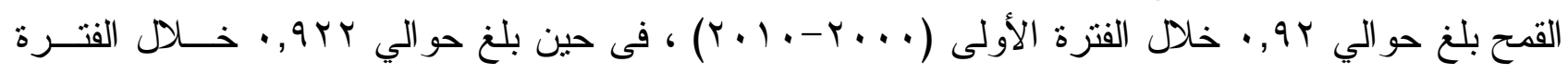

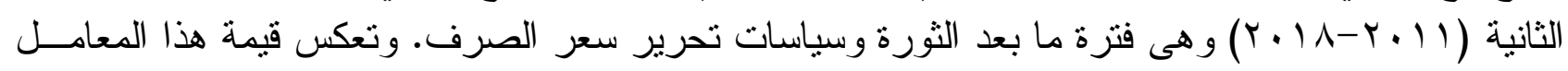

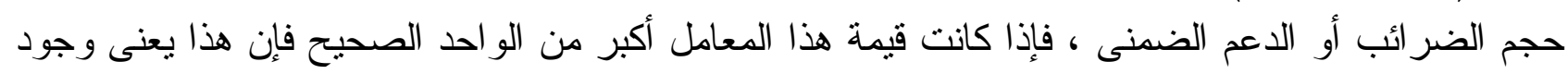

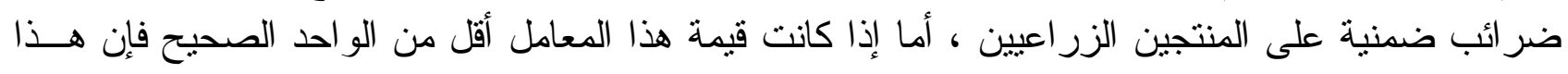

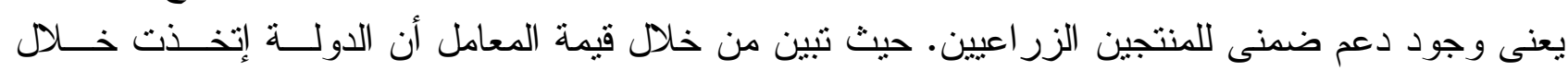

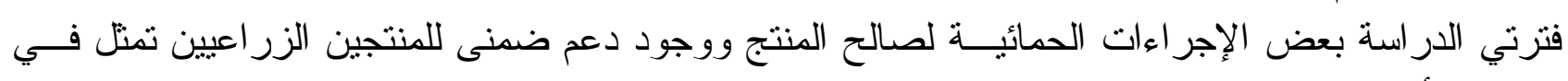
إنخفاض أسعارمستلزمات ومو العمد الإد الإنتاج.

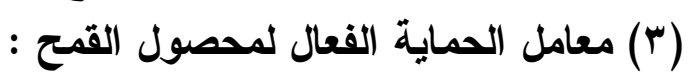

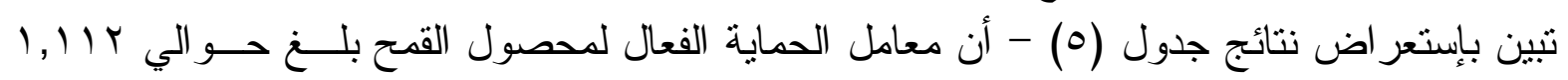

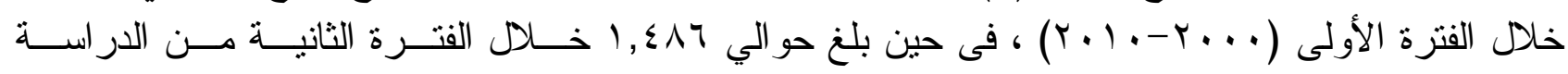

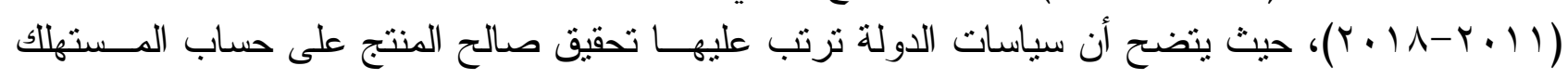

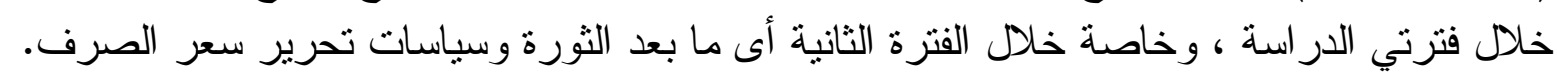




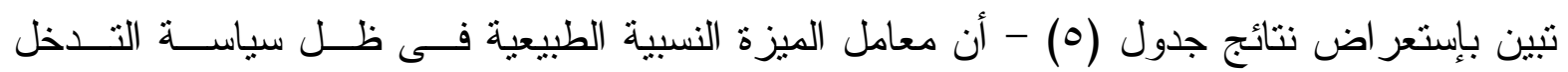

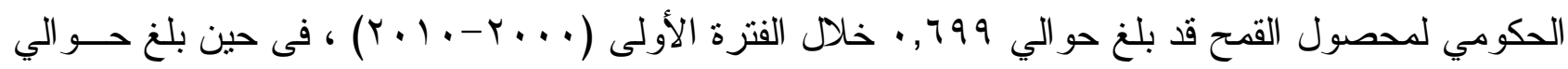

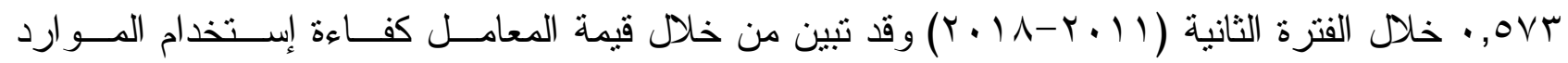

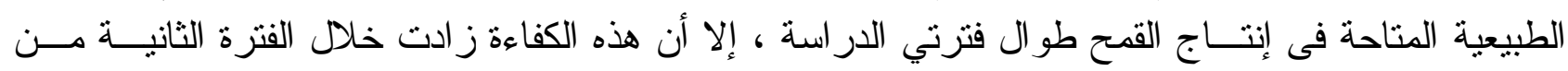

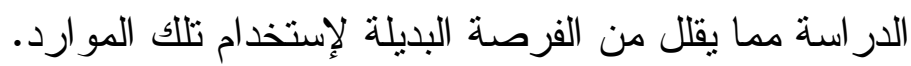
(0) معامل الميزة النسبية الطبيعية فى ظل التخلى عن سياسة التذخل الحكومي فى سعر الصرف:

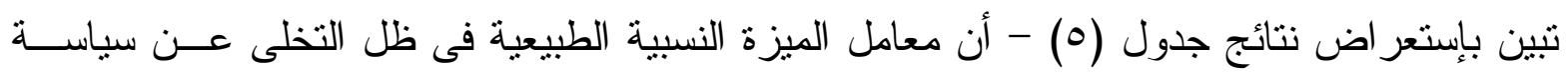

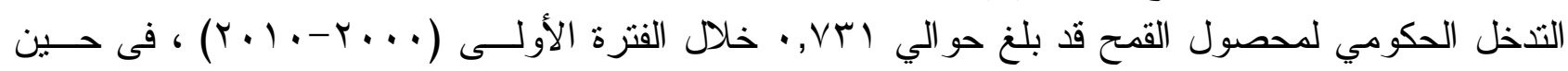

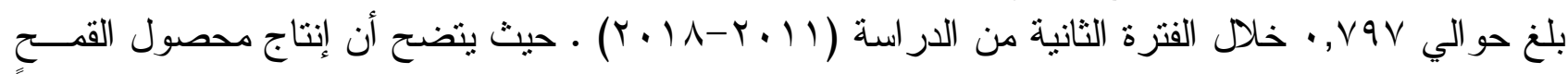

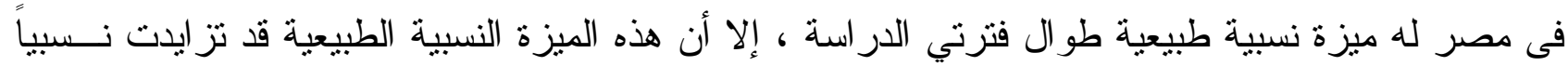

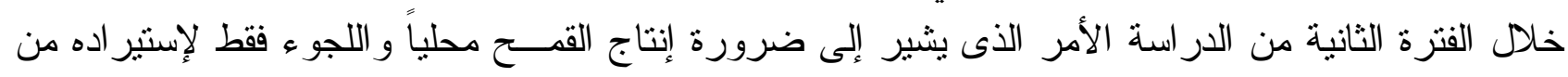
الخار ج لمو اجهة الفجوة الناتجة من زيادة إستهالاك القمح.

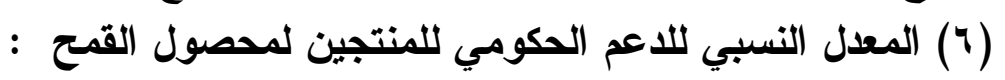

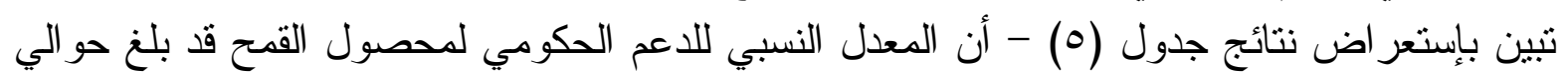

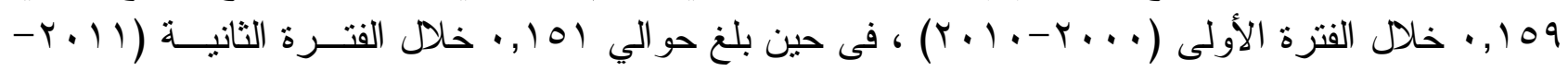

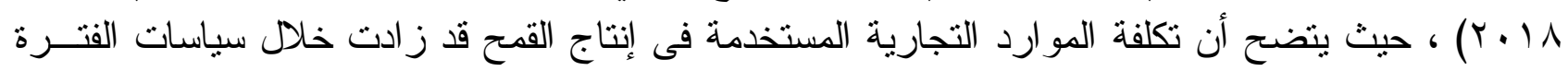
الثانية بما يعنى إنخفاض المعدل النسبي للاعم الحكومي خلال تلاك الفترة عما كان عليه فى الفترة الأولى.

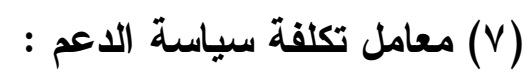

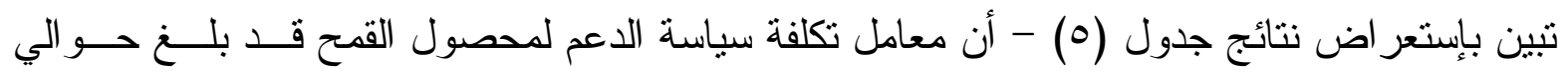

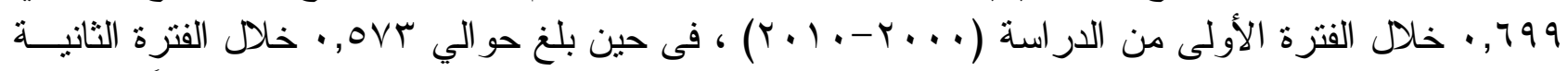

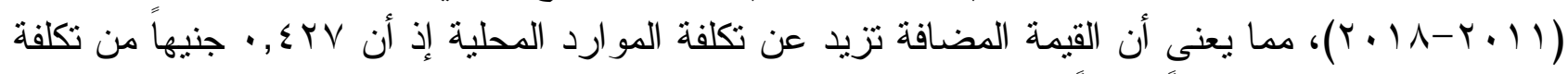

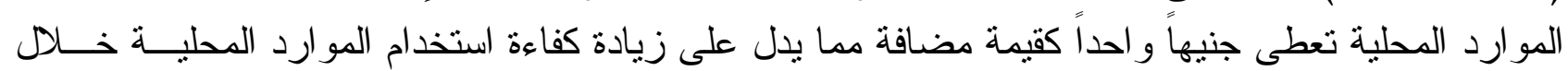
سباسات تلك الفترة.

جدول رقم (0) - نتائج مصفوفة تحليل السياسات لقياس أثر السياسات الزراعية على محصول القمح

\begin{tabular}{|c|c|c|}
\hline متوسط الثقانية & متوسط الفترة & البيـــــــــان \\
\hline 1.394 & 1.079 & معامل الحماية الإسمية للإنتاج \\
\hline 0.922 & 0.920 & معامل الحماية الإسمية لمستلزمات الإتتاج \\
\hline 1.486 & 1.112 & معامل الحمائة الفُعال \\
\hline 0.573 & 0.699 & معامل الميزة النسبية الطبيعية (تكلفة الموارد المحلية) في ظل سياسة التدخل الحكومي \\
\hline 0.797 & 0.731 & معامل الميزة النسبية الطبيعية في ظل التخلى عن سياسة التّخل الحكومي \\
\hline 0.151 & 0.159 & المعدل النسبي للاعم الحكومي للمنتجين \\
\hline 0.573 & 0.699 & معامل تكلفة سياستة الاعم \\
\hline
\end{tabular}

المصدر : جمعت وحسبث من ملحق رقم (1) بالبحث.

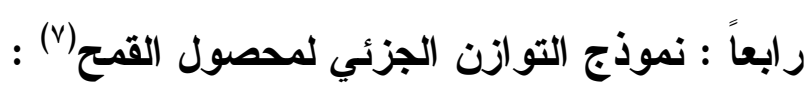

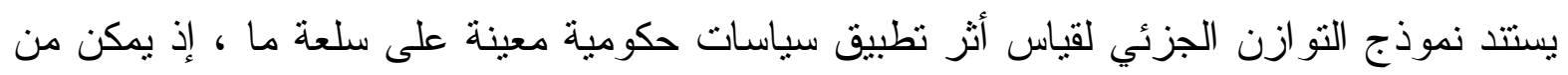

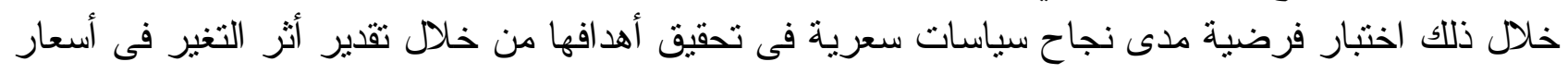
كل من المنتج و المستهلك على مستويات المتغير ات الاقتصادية للسلعة خاصة مستويات الطلب الإستهلاكى 
ومستويات العرض الإنتاجي. وينطوى نموذج التوازن الجزئي على مجموعة من المعادلات التى يمكن من

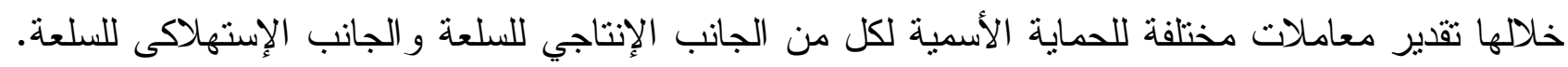

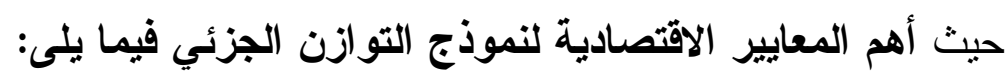

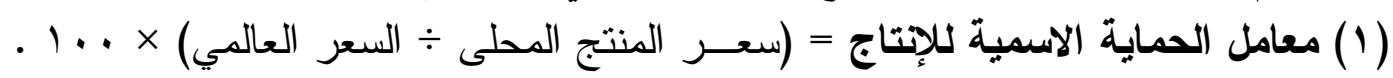

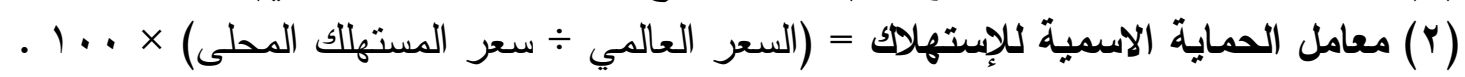

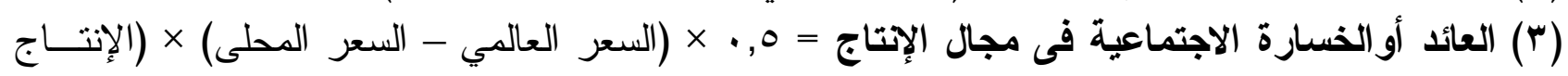

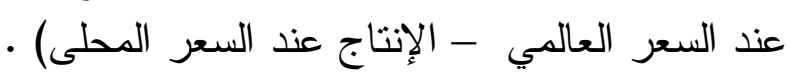

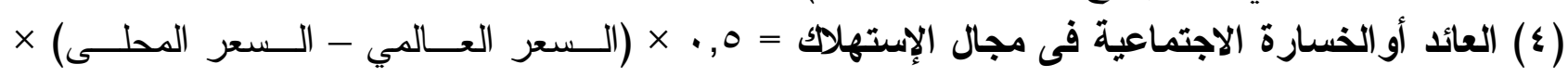

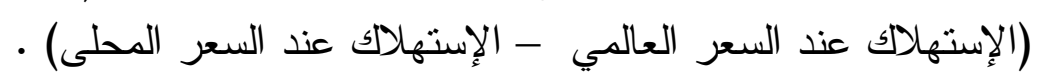
(•) إجمالي العائد أو الخسارة الاجتماعية القومية = مجموع العوائد أو الخسارة الاجتماعية فى مجال كـلـ الإنـ

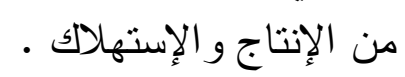
(7) الآثار التوزيعية للمستهلكين = الإستهلاك عند السعر المحلى × (السعر العالمي - السعر المحلـى) +

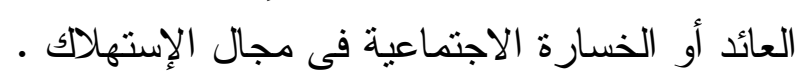

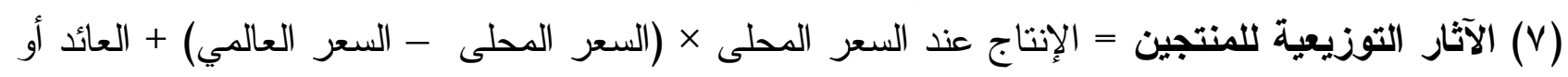

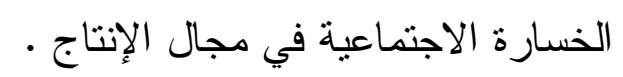
(^) التغير فى الإير ادات الحكومية = (الآثار التوزيعية للمستهلكين + الآثار التوزيعية للمنتجين) + إجمـالي

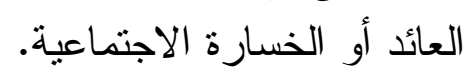
(9) التغير فى حصيلة النقد الأجنبي = سعر الحدود × (الزيادة أو النقص فـي الإســتهلاك - الزيــادة أو

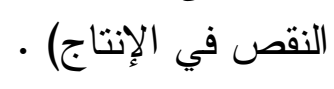

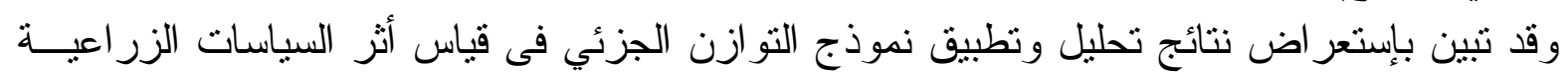

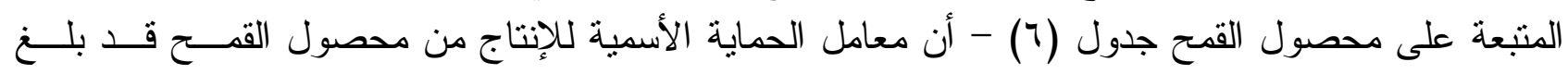

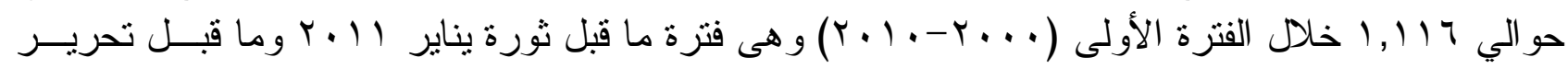

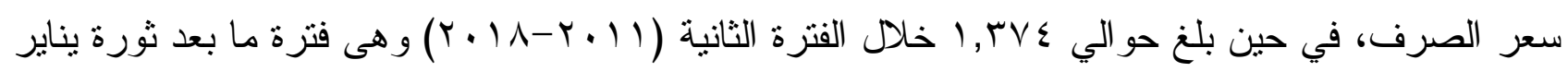

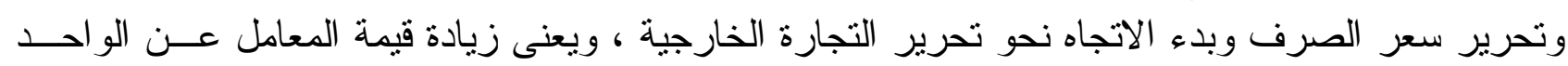

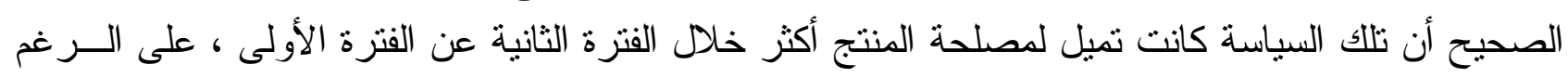
من أن قيمة هذا المعامل فى كلا الفترنين كانت فى مصلحة المنتج.

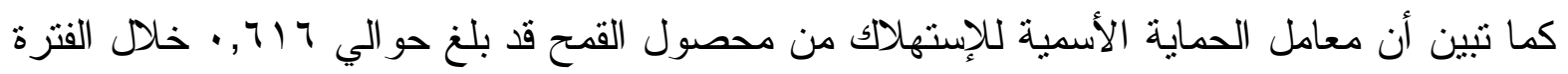

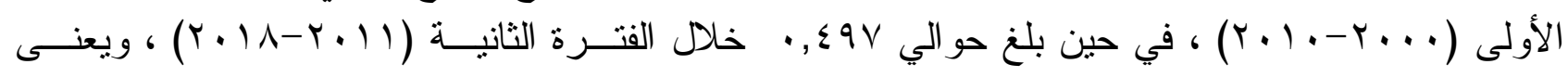

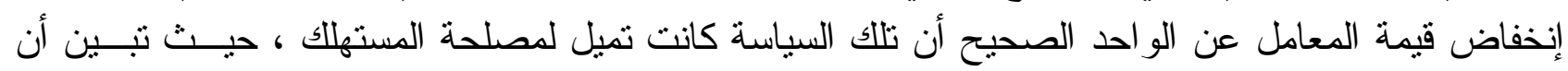
إتباع كل من السياستين كانتا فى صالح المستهلك لمحصول القمح إلا أنها كانت تميل لمصلحة المستهلك أكثر

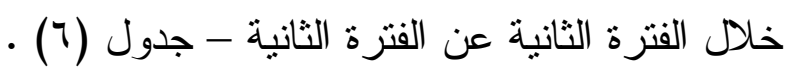

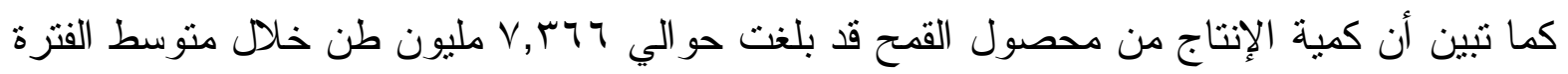

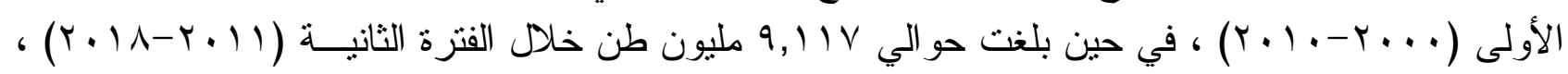

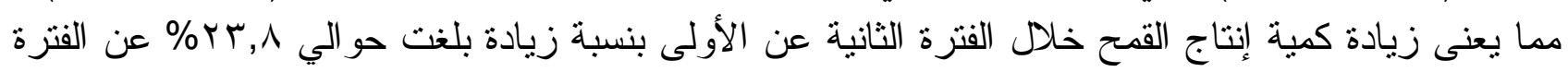

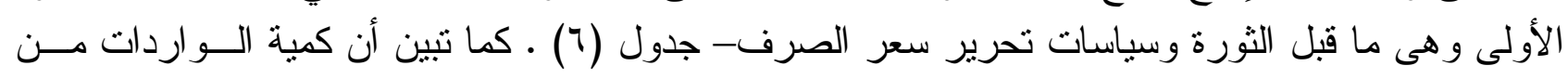

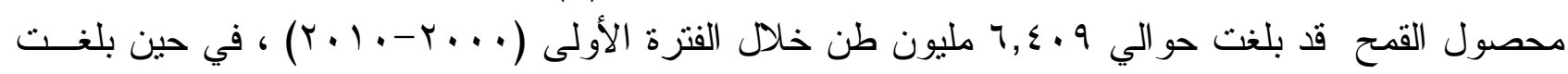




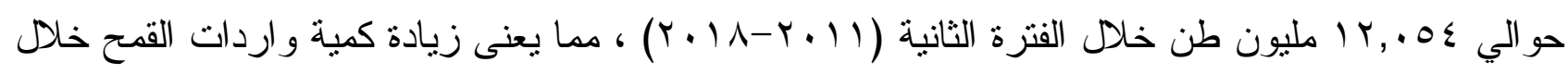

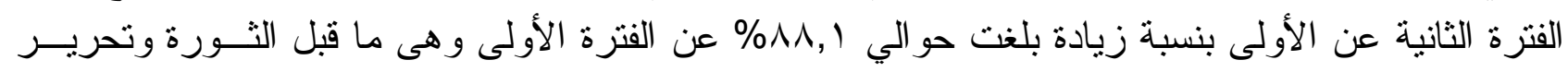

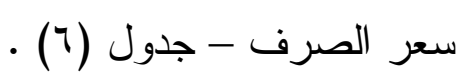

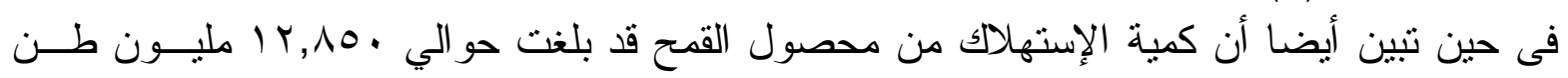

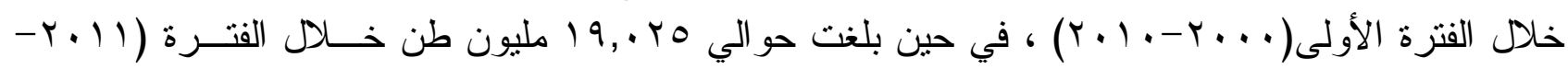

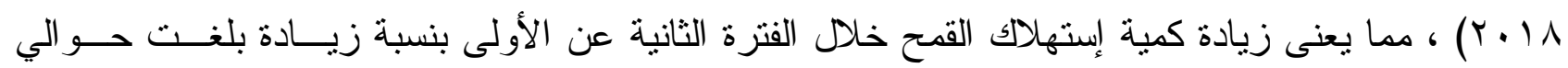
ـ \&, 1

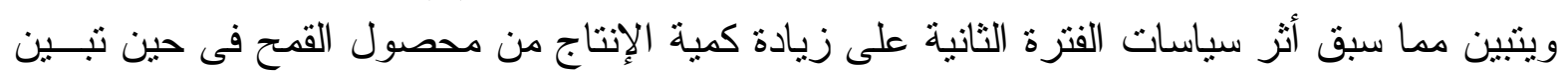

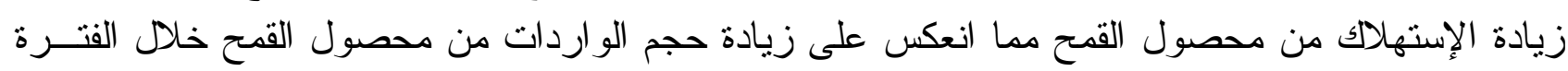

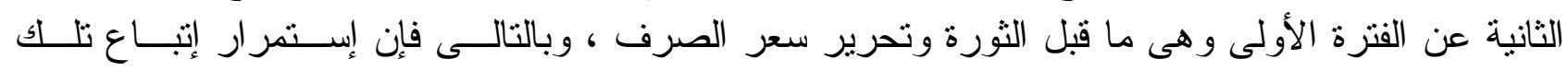

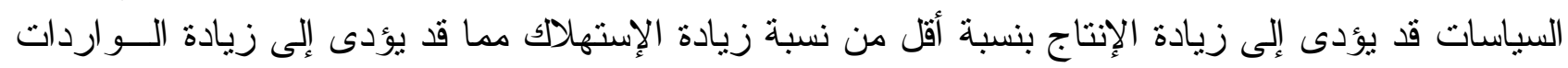

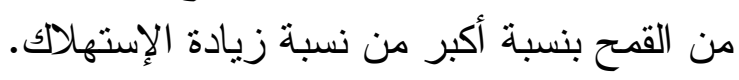

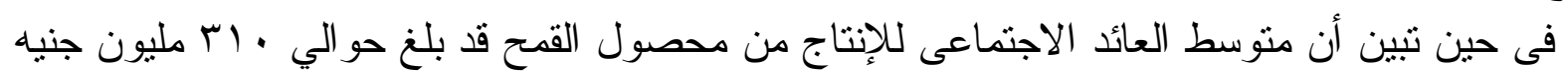

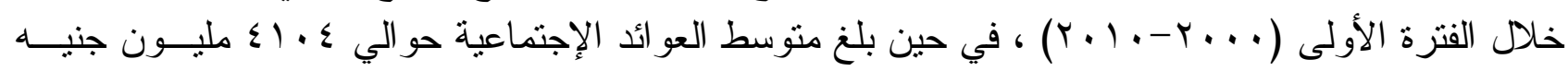

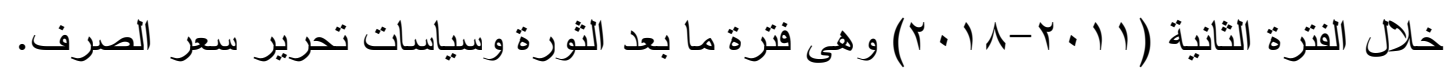

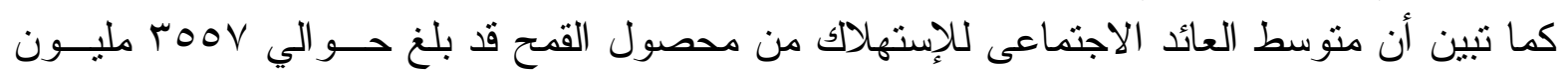

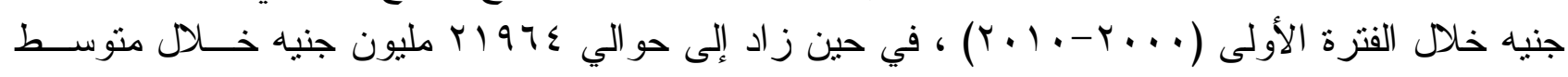

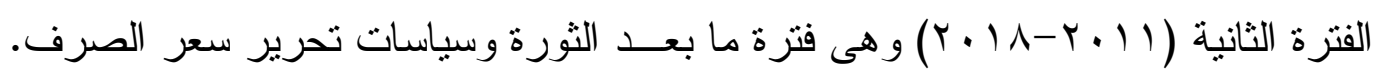

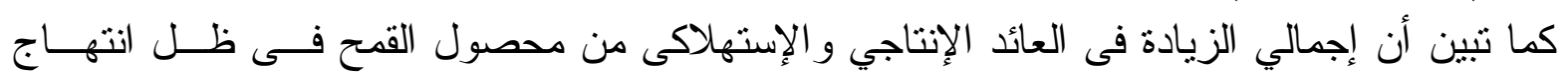

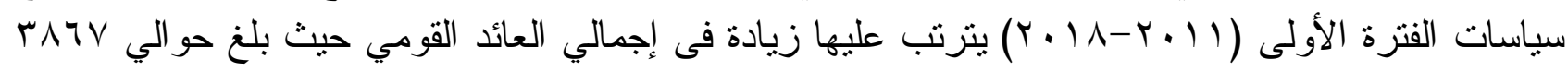

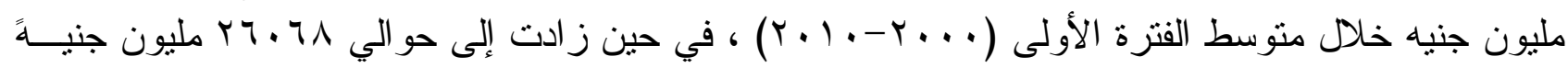

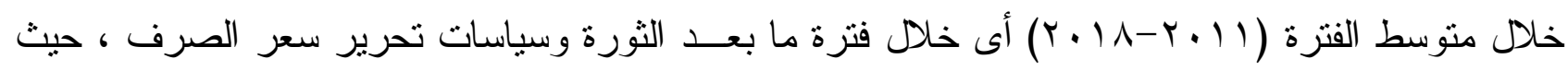
تزتب عليها زيادة فى إجمالي العائد القومي بلغ حو الي ب, ب r مليار جنيه عن متوسط الفترة الأولى - جــدول

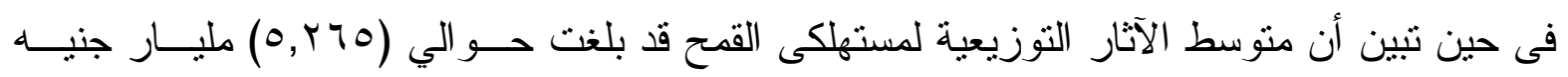

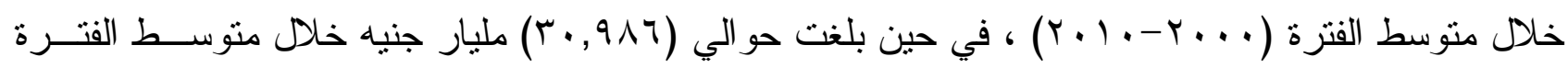

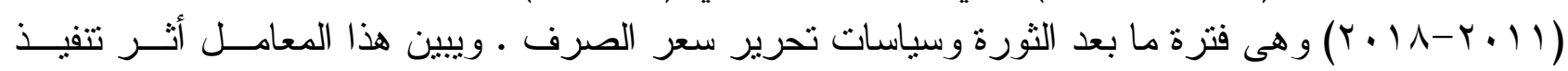

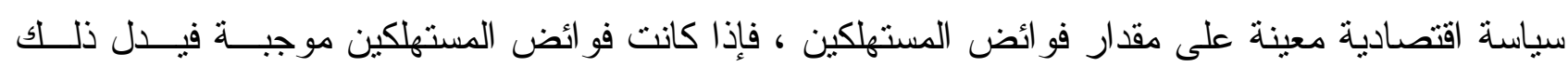

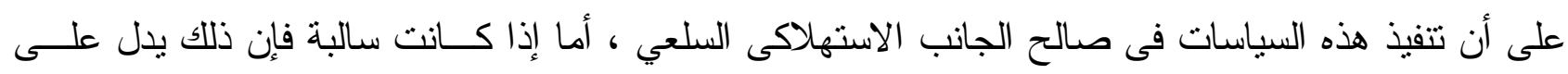

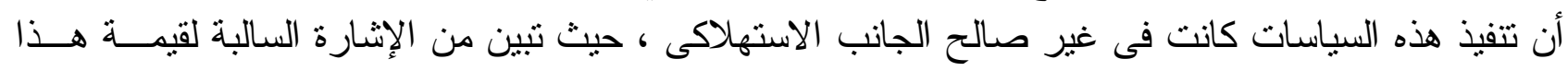

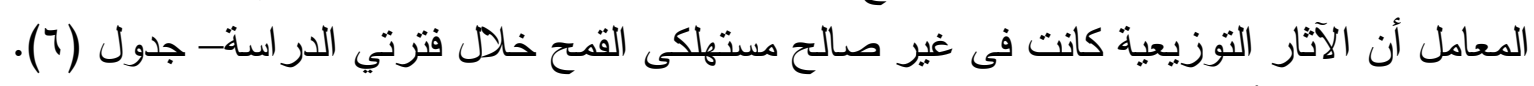

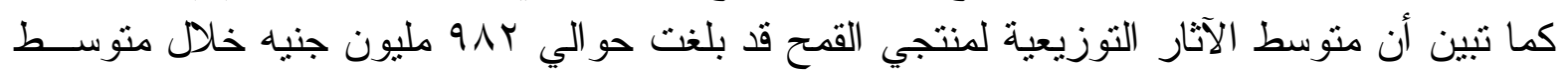

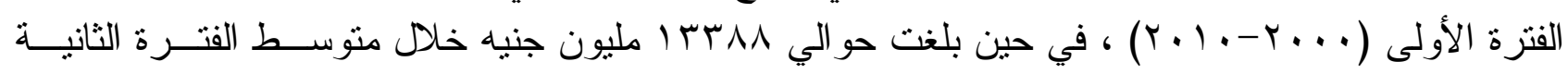

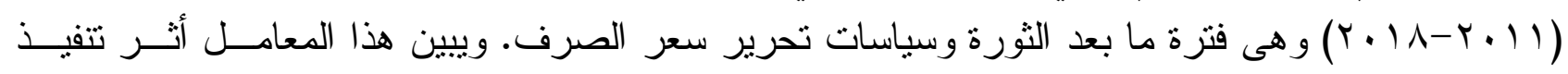

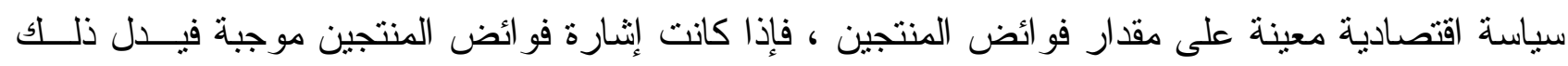

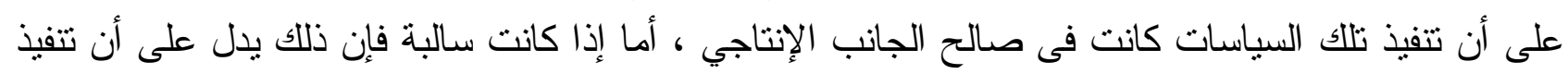




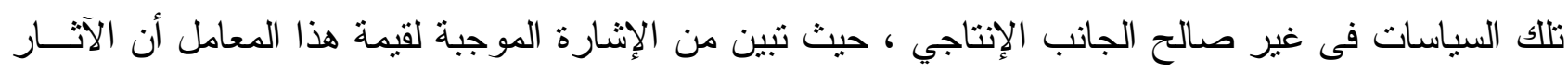

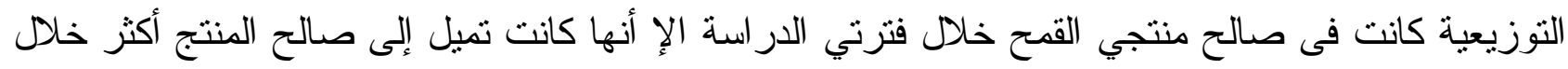

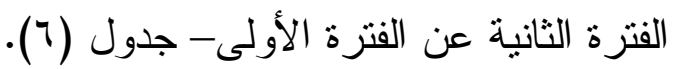

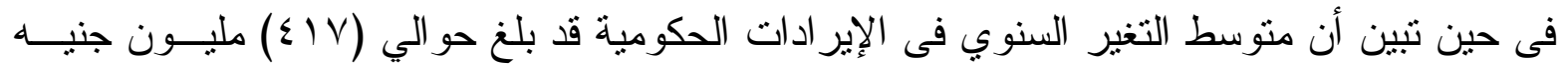

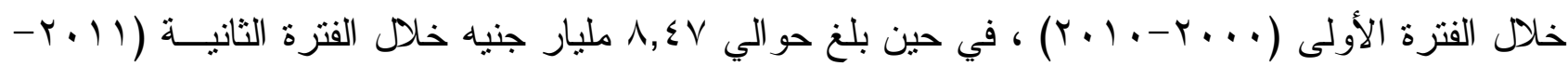

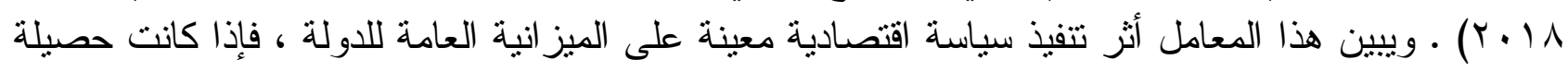

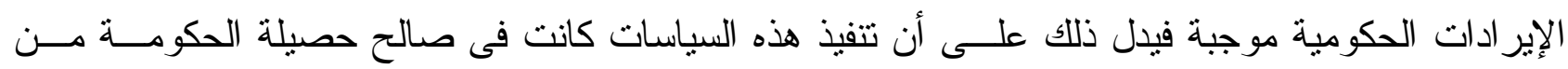

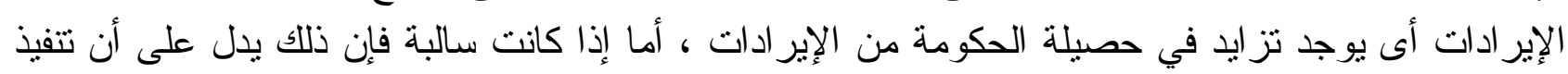

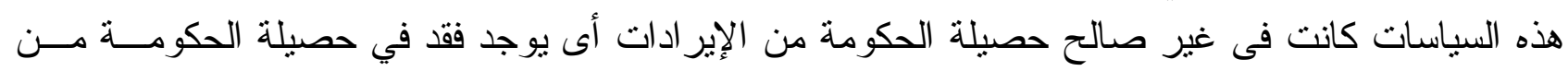

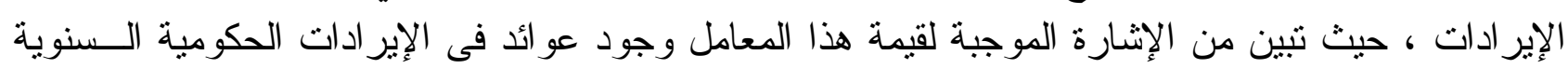

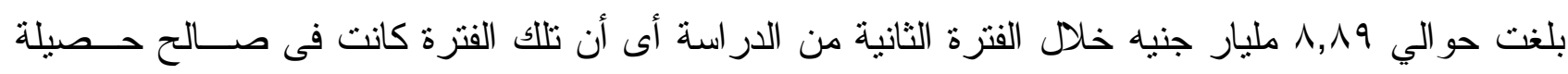

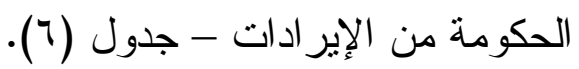

جدول (؟) : نتائج التوازن الجزئي لمحصول القمح خلا فترتي الار استة

\begin{tabular}{|c|c|c|c|}
\hline متوسط الفترة الثناتية & 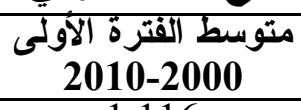 & الفئة & البيــــــــان \\
\hline 1.374 & 1.116 & - & الحماية الاسمية للإنتاج \\
\hline 0.497 & 0.616 & - & 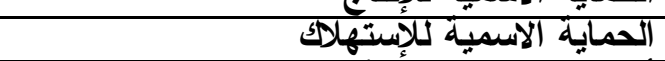 \\
\hline & & & آثّر السياسات على الأمن الغذائي القمحى: \\
\hline 9117 & 7366 & ألف طن & - الإنتاج - \\
\hline 12054 & 6409 & آلف طن & التواردات \\
\hline 19025 & 12850 & 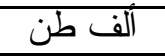 & - - الإستهلاك \\
\hline & & & الاثًار الأقتَّادية الناشُشئة: \\
\hline 4104 & 310 & مليون جنيه & - العائد أو الخسارة الاجتماعية فى الإتتاج \\
\hline 21964 & 3557 & مليون جنيه & العائد أو الخسارة الاجتماعية في الإستهلالك \\
\hline 26068 & 3867 & مليون جنيه & إجمالي العائد أو الخسارة الاجتماعية \\
\hline-30986 & -5265 & مليون جنيه & الآثار آلتوزيعية للمستهلكين \\
\hline 13388 & 982 & مليون جنيه & الاتثار التوزيعية للمنتجين \\
\hline 8470 & -417 & مليون جنيه & التغير فى الإيرادات الحكومية \\
\hline 21529 & 4132 & مليون جنيه & التغير فى حصيلة النقـ الأجنبي \\
\hline
\end{tabular}

المصدر : جمعت وحسبت من جدول رقم (1) بالبحث.

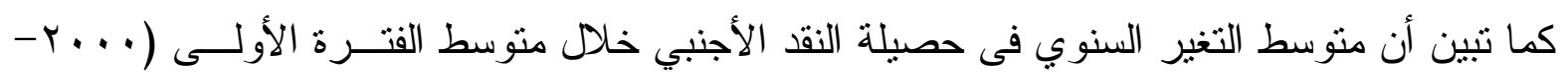

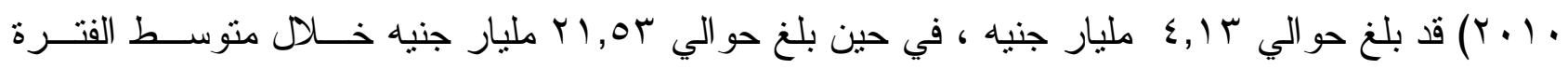

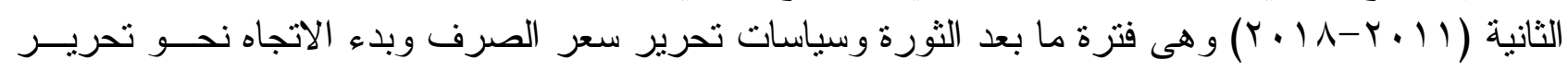

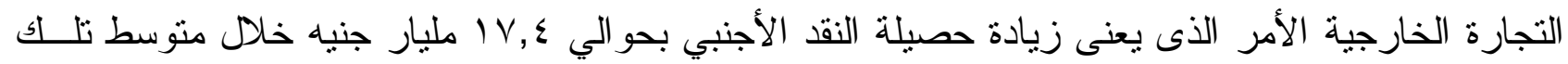

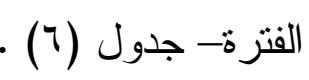

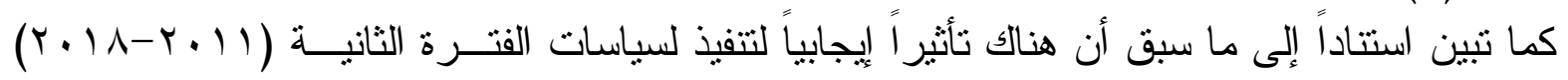

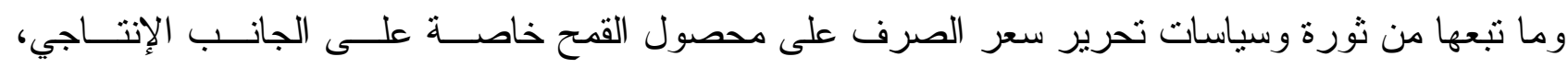

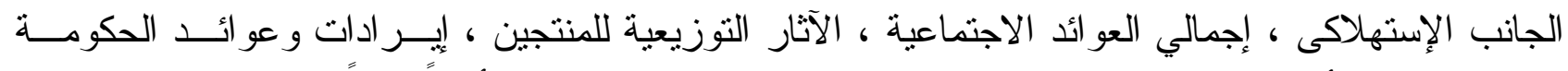

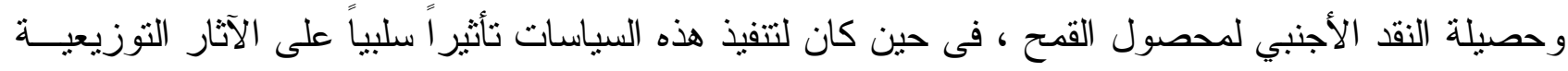
لمستهلكى القمح خلال فترتي الدر اسة. 


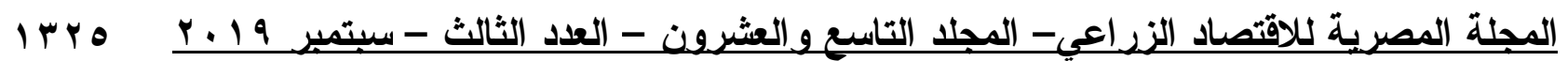

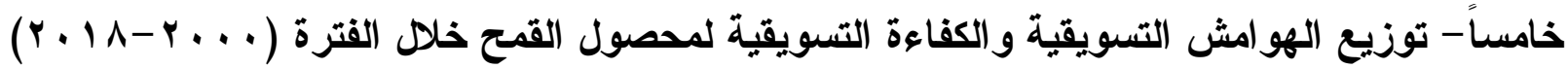

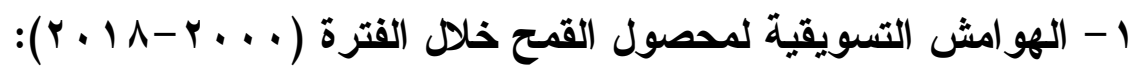
يبين جدول (V) نتائج توزيع جنيه المستهلك بين كل من المنتج وناجر الجملة وتاجر التجزئة لمحصول

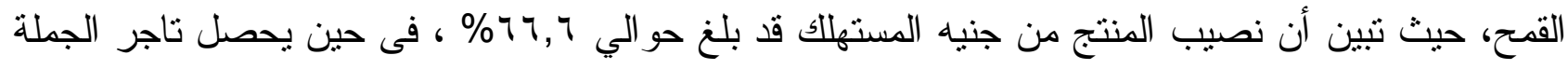

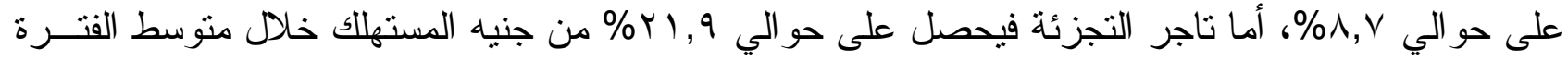
$\cdot(r \cdot 1 \wedge-r \cdot . \cdot)$

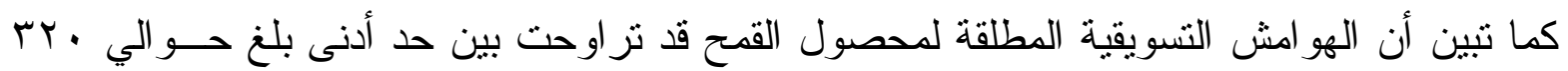

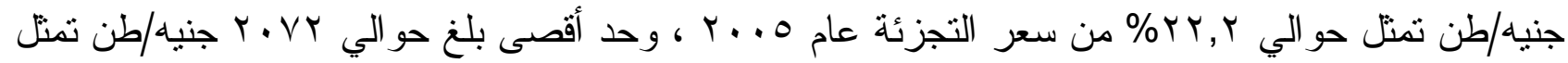

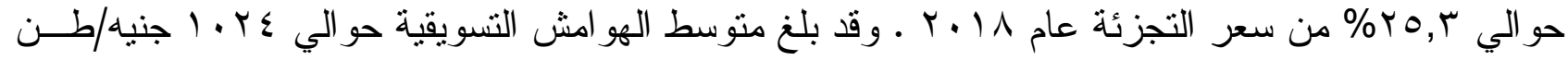

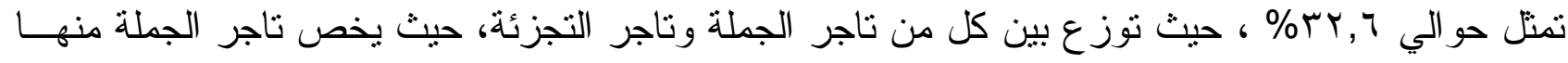

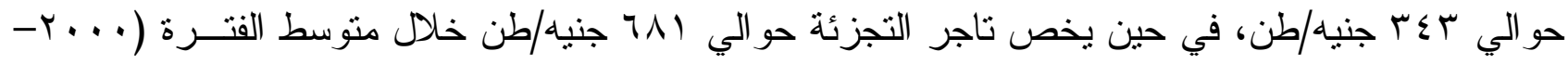
$\cdot(r)$.

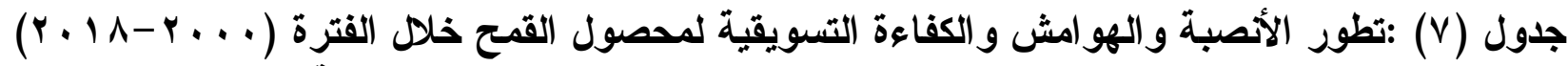

\begin{tabular}{|c|c|c|c|c|c|c|c|c|c|c|c|}
\hline \multirow{3}{*}{ التسويقية } & \multicolumn{6}{|c|}{ الهو امش التسويقية } & \multirow{2}{*}{\multicolumn{4}{|c|}{ توزيع الأنصبة }} & \multirow{3}{*}{ السنة } \\
\hline & \multicolumn{2}{|c|}{ تجزئة - منتج } & \multicolumn{2}{|c|}{ تجزئنة -جملة } & \multicolumn{2}{|c|}{ جملة - منتج } & & & & & \\
\hline & $\%$ & مطلق & $\%$ & مطلق & $\%$ & مطلق & الوسطاء & التجزئة & الجملة & المنتج & \\
\hline 42.4 & 38.0 & 425 & 35.0 & 392 & 4.6 & 34 & 38.0 & 35.0 & 3.0 & 62.0 & 2000 \\
\hline 43.1 & 37.4 & 419 & 34.5 & 386 & 4.5 & 33 & 37.4 & 34.5 & 3.0 & 62.6 & 2001 \\
\hline 42.0 & 38.6 & 452 & 31.7 & 371 & 10.2 & 81 & 38.6 & 31.7 & 7.0 & 61.4 & 2002 \\
\hline 46.6 & 32.4 & 411 & 22.3 & 283 & 12.9 & 128 & 32.4 & 22.3 & 10.1 & 67.6 & 2003 \\
\hline 37.1 & 39.8 & 660 & 26.0 & 431 & 18.6 & 229 & 39.8 & 26.0 & 13.8 & 60.2 & 2004 \\
\hline 56.3 & 22.2 & 320 & 12.0 & 173 & 11.6 & 147 & 22.2 & 12.0 & 10.2 & 77.8 & 2005 \\
\hline 55.8 & 24.4 & 363 & 13.3 & 198 & 12.8 & 165 & 24.4 & 13.3 & 11.1 & 75.6 & 2006 \\
\hline 43.5 & 37.3 & 687 & 22.9 & 422 & 18.7 & 265 & 37.3 & 22.9 & 14.4 & 62.7 & 2007 \\
\hline 57.7 & 24.2 & 497 & 10.0 & 204 & 15.9 & 293 & 24.2 & 10.0 & 14.3 & 75.8 & 2008 \\
\hline 45.2 & 35.5 & 887 & 28.6 & 715 & 9.6 & 172 & 35.5 & 28.6 & 6.9 & 64.5 & 2009 \\
\hline 42.7 & 39.4 & 1177 & 34.9 & 1044 & 6.8 & 133 & 39.4 & 34.9 & 4.4 & 60.6 & 2010 \\
\hline 43.9 & 32.4 & 1123 & 27.0 & 936 & 7.4 & 188 & 32.4 & 27.0 & 5.4 & 67.6 & 2011 \\
\hline 46.8 & 30.4 & 1100 & 24.7 & 896 & 7.5 & 204 & 30.4 & 24.7 & 5.6 & 69.6 & 2012 \\
\hline 42.2 & 36.3 & 1470 & 26.8 & 1085 & 13.0 & 385 & 36.3 & 26.8 & 9.5 & 63.7 & 2013 \\
\hline 43.3 & 36.9 & 1600 & 24.9 & 1080 & 16.0 & 520 & 36.9 & 24.9 & 12.0 & 63.1 & 2014 \\
\hline 41.2 & 40.0 & 1837 & 23.5 & 1080 & 21.6 & 757 & 40.0 & 23.5 & 16.5 & 60.0 & 2015 \\
\hline 41.9 & 34.1 & 1897 & 19.4 & 1081 & 18.2 & 816 & 34.1 & 19.4 & 14.6 & 65.9 & 2016 \\
\hline 44.9 & 25.3 & 2060 & 13.3 & 1080 & 13.9 & 980 & 25.3 & 13.3 & 12.0 & 74.7 & 2017 \\
\hline 49.3 & 25.3 & 2072 & 13.2 & 1082 & 13.9 & 990 & 25.3 & 13.2 & 12.1 & 74.7 & 2018 \\
\hline 45.3 & 32.6 & 1024 & 21.9 & 681 & 11.4 & 343 & 32.6 & 21.9 & 8.7 & 66.6 & المتوسط \\
\hline 46.1 & 32.9 & 573 & 22.6 & 420 & $\overline{10.4}$ & 153 & 32.9 & 22.6 & 7.8 & 66.1 & متوسط (2010-2000) \\
\hline 44.1 & 32.2 & 1645 & 20.8 & 1040 & $\overline{13.1}$ & 605 & 32.2 & 20.8 & 10.3 & 67.2 & متوسط (2018-2011) \\
\hline-0.2 & -0.7 & 1072 & -1.8 & 620 & 2.7 & 452 & -0.7 & -1.8 & 2.5 & 1.1 & ألتغير بين الفترتين \\
\hline-4.4 & -2.1 & 187.3 & -8.0 & 147.6 & 26.5 & 296.4 & -2.1 & -8.0 & 32.2 & 1.7 & نسبة التغير \\
\hline
\end{tabular}

المصدر: جمعت وحسبت من بيانات جدول رقم (1 ) بالبحث .

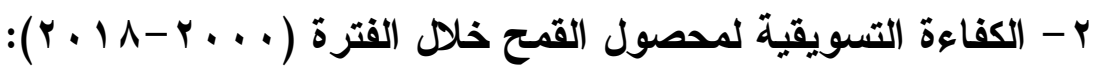
يعتمد حساب التكاليف التسويقية على تكاليف التسويق وتكاليف الإنتاج ، حيث أن تدنية التكاليف التسويقية تؤدى إلى معظمة الكفاءة ، و تحسب الكفاءة التسويقية بخار ج قسمة التكاليف التسويقية على (مجموع التكاليف التسويقية و التكاليف الإنتاجية).

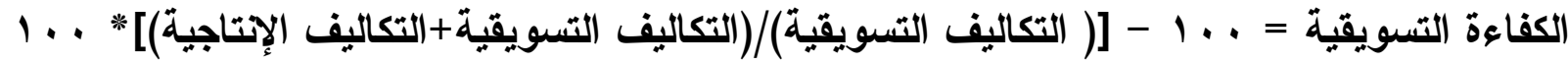




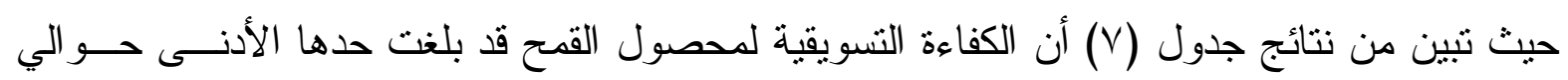

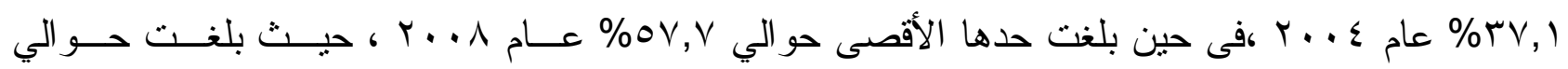

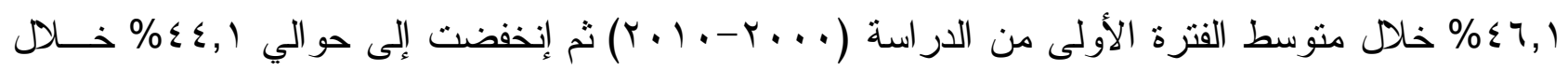

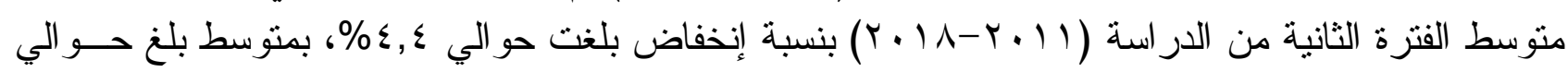

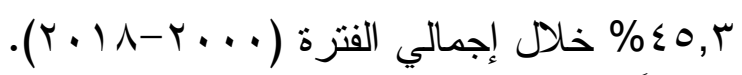

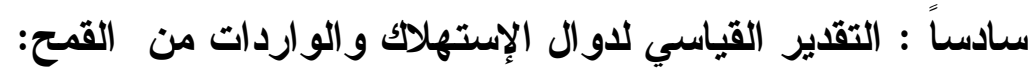

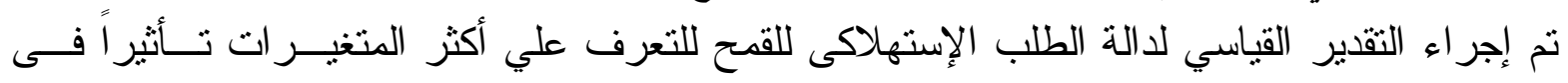
إجمالي الطلب الإستهلاكى من القمح بالألف طن (Yt) ، و وعدة متغير ات تفسيرية متمنلة فـى :

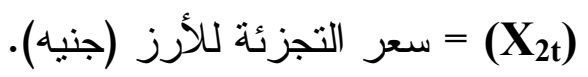
. ( (ألف (X) $=\left(\mathbf{X}_{3 t}\right)$ ( الاخل الفردي النقدي (جنيه).

كما نم إجر اء التقدير القياسي لدالة واردات القمح للتعرف علي أكثر المتغير ات تــأثنير اً فــى إجمــالي

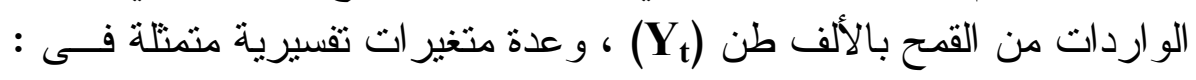

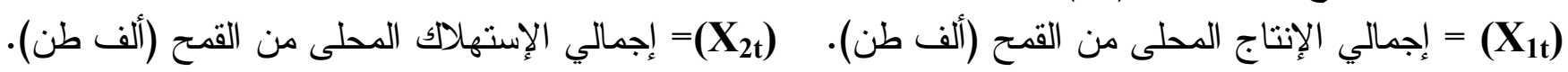
( متوسط نصيب الفرد من القمح (كجم/فرد) (X) ( X $=\left(\mathbf{X}_{3 t}\right)$ ( الأنل الفردي النقدي (Xt)

(

وذللك بعد استخدام الصور الرياضية المختلفة للدو ال وهى الخطية و النصف لو غاريتمية و اللوغاريتمية المزدوجة، حيث تم إختيار أفضل هذه الصور إستتاداً إلى قيم (t) لمعاملات المتغيرات المستقلة التى تتضمنها

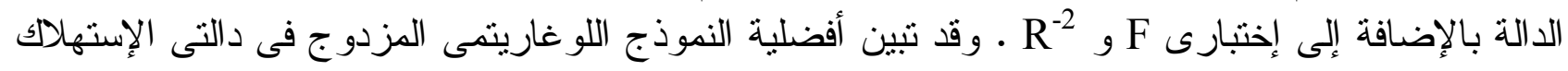
و الواردات من القمح.

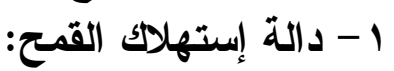

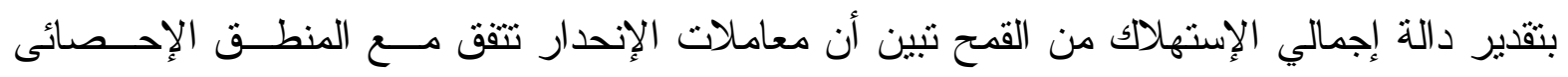

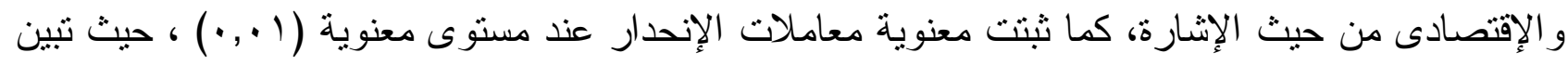

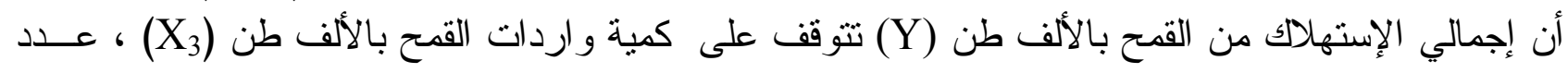

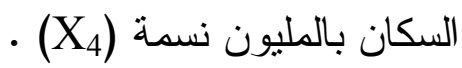

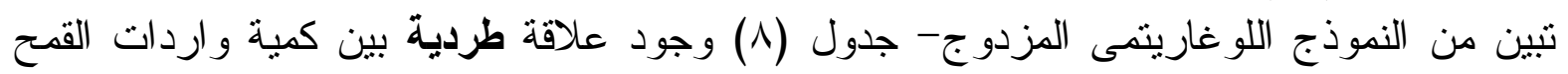

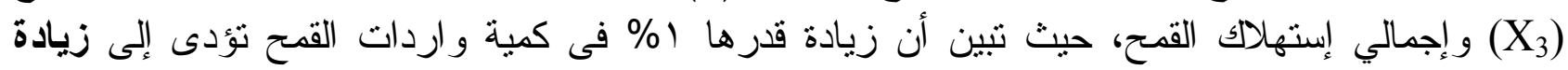

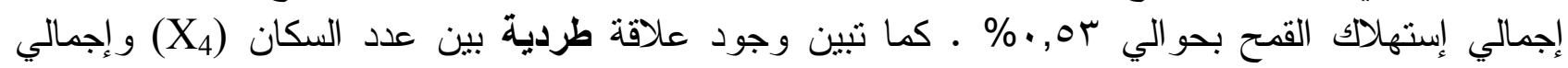

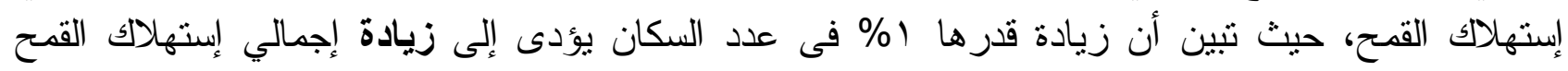

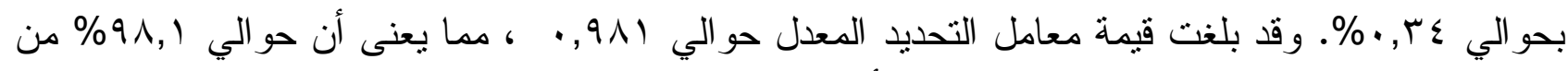
التغير ات فى الكمية المستهلكة من القمح يعكس تأثنير ها متغير ات النموذج سالفة الذكر .

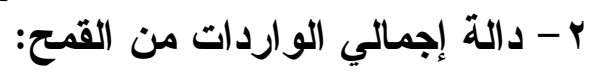

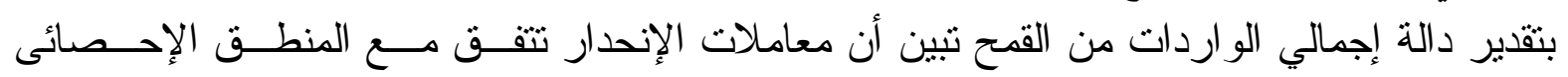

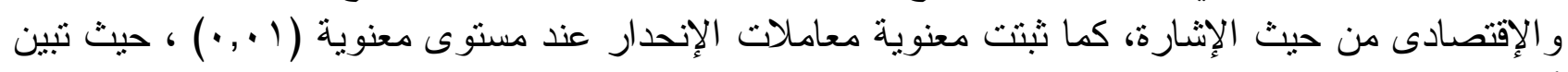

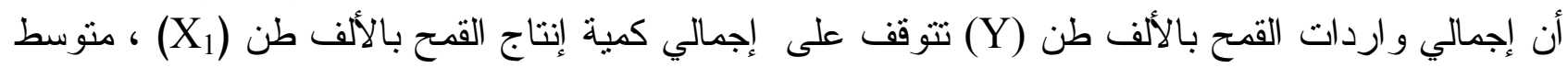
نصيب الفرد من القمح بالكجم/فرد (X) ) ، عدد السكان بالمليون نسمة (X) ) ، الدخل الفردي النفدى الـسنوي 


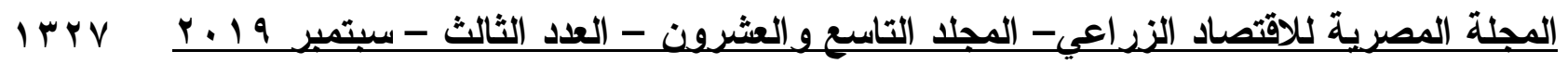
حيث تبين من النموذج اللوغاريتمى المزدوج- جدول (^) وجود علاقة عكسية بين إجمالي إنتاج

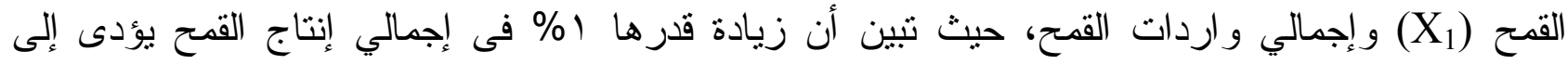
إنخفاض إجمالي واردات القمح بحو الي 90, • \% .فى حين تنين وجود علاقة طردية بين منوسط نصيب الفرد

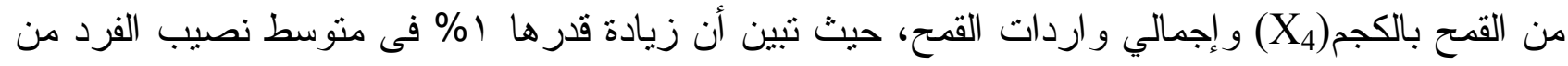

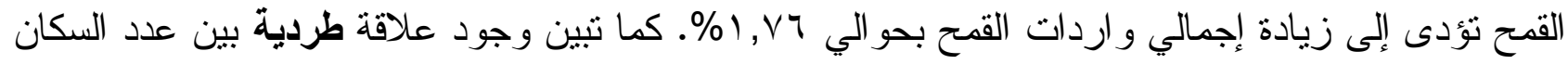

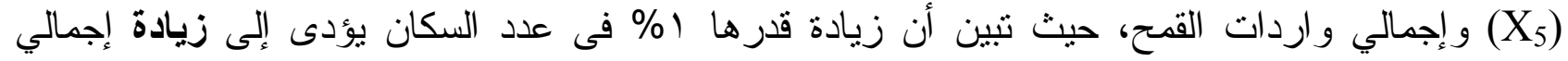

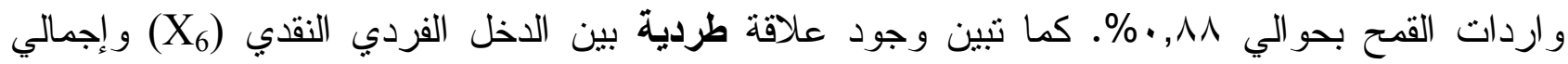
و اردات القمح، حيث تبين أن زيادة قدرها إ) في إجمالي الدخل الفردي النقدي يؤدى إلى زيادة إجمالي

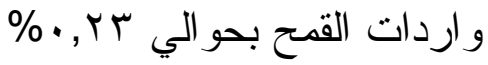

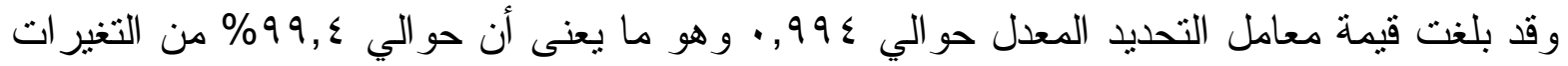
فى كمية و اردات القمح يعكس تأثثر ها متغير ات النموذج سالفة الذكر .

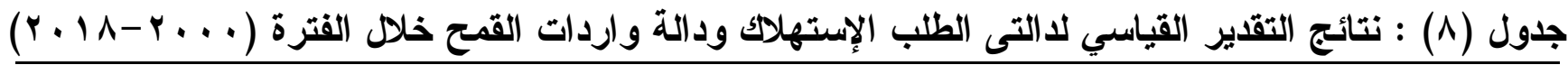

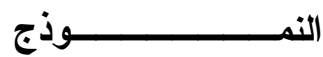

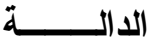

$\log \hat{\mathrm{Y}}_{\mathrm{t}}=3.461+0.529 \log \mathrm{X}_{3}+0.344 \log \mathrm{X}_{4}$ $(10.02)^{* *}(19.42)^{* *} \quad(3.19)^{* *}$

$\mathbf{F}=465^{* *} \quad \mathbf{R}^{-2}=\mathbf{0 . 9 8 1} \quad$ D. W $=1.3$ دالة الطلب الإستهلاكى $\log \hat{Y}_{t}=2.084-0.947 \log X_{1}+1.763 \log X_{4}+0.877 \log X_{5}+0.226 \log X_{6}$ $\mathbf{F}=771^{* *} \mathbf{R}^{-2}=\mathbf{0 . 9 9 4} \quad$ D. $\mathbf{W}=1.7$ $(2.34)^{*}$ $(3.45)^{*}$

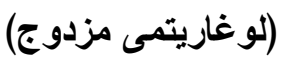
دالة الواردات

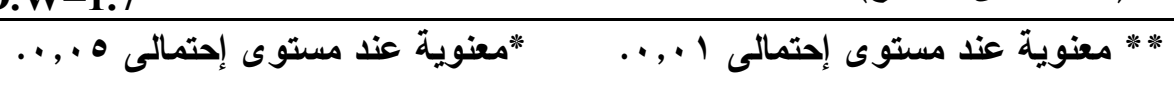
المصدر : جمعت وحسبت من بيانات جدول رقم (1) بالبحث. سابعاً : التنبؤ بحجم الفجوة من محصول القمح حتى عام ه ب . ب :

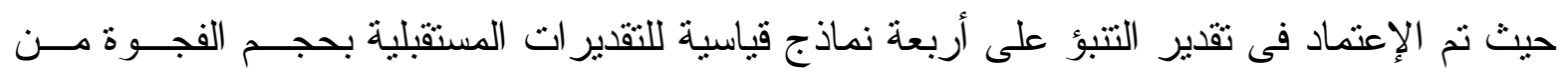
محصول القمح وهى : (1) (1) التقديرات المتوقعة بإستخدام نموذج معدل إزدياد الطلب(ז') على محصول القمح :

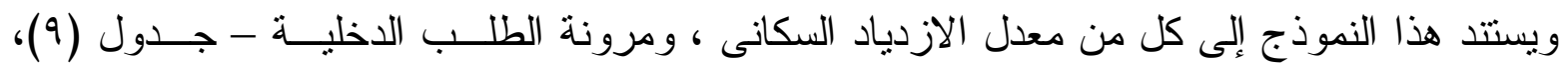
ومعدل ازدياد الدخل الفردي الحقيقي ، ويأخذ الصورة الرياضية : (E) معدل الازدياد السنوي في الطلب على القمح، (E) معدل

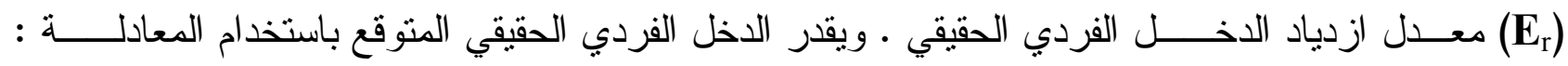

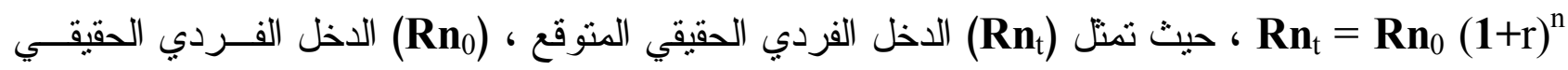

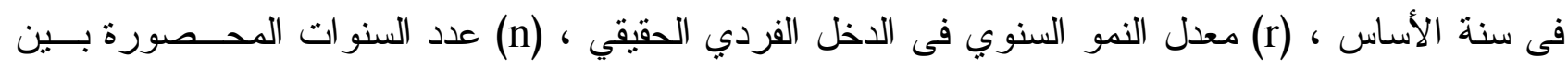

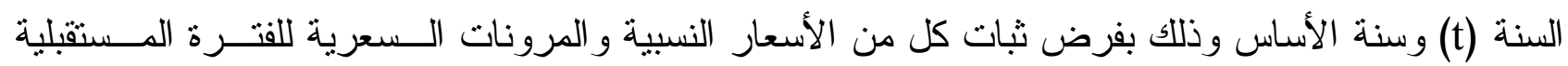
لصعوبة التتبؤ الدقيق بها.

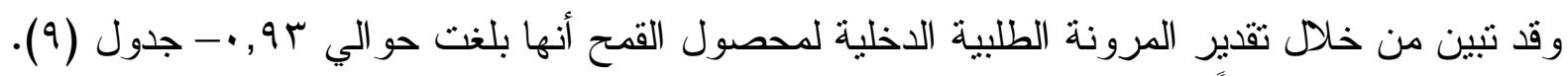

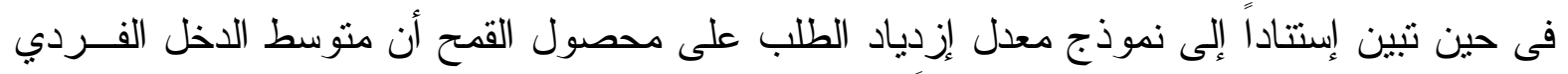

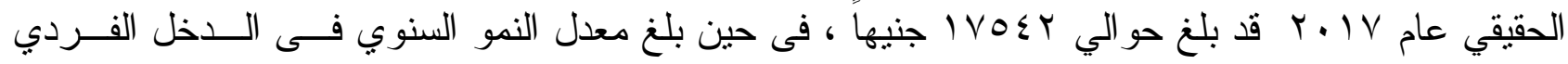

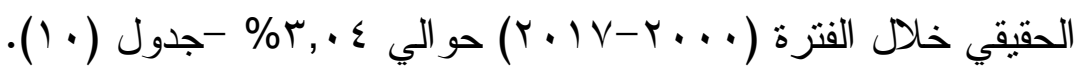




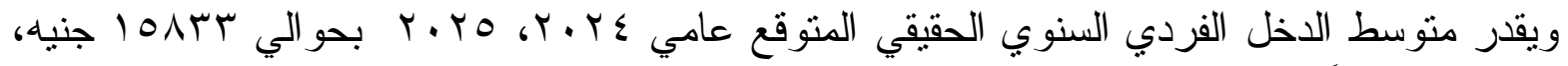
وحو الي 0 اباج 1 جنيهاً على التو الي بإفتر اض ثبات معدل النمو السنوي السابق الإشارة إليه.

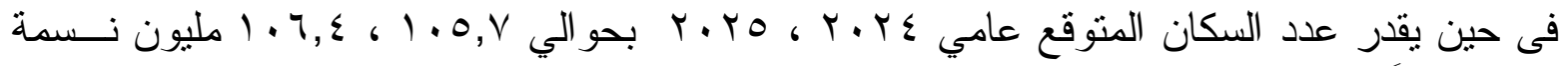

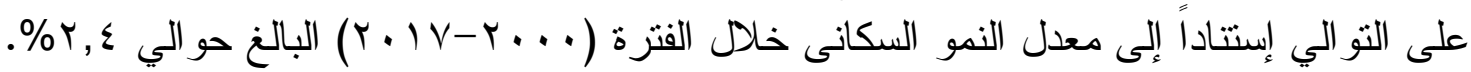
جدول (9) - مرونة الإنفاق الكلى للاخل والمرونة الطلبية الإفاقية والمرونة الطلبية الاخلية لمحصول حولئي

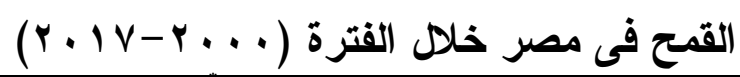

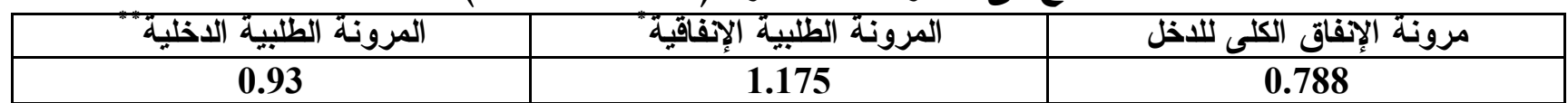

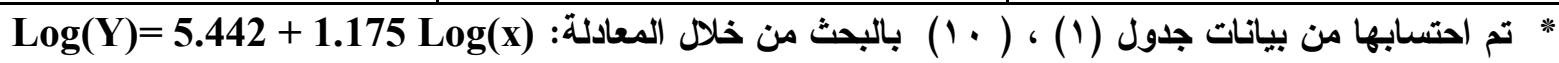

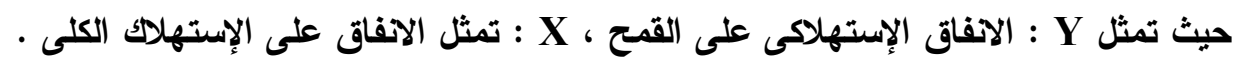

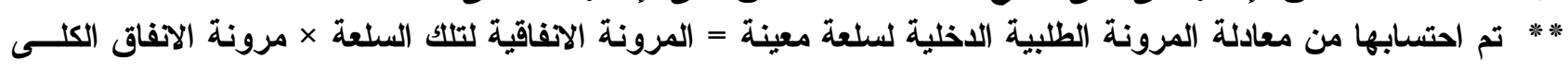

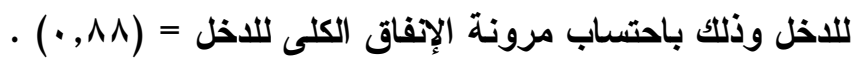
المصدر : جمت وحسبت من :

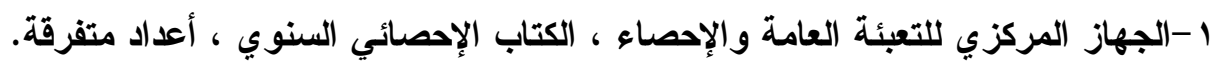

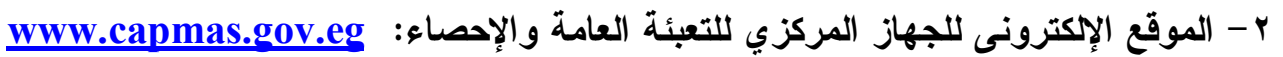
r- وزارة الزر اعة و إستصلاح الأراضي، الإدارة المركزية للاقتصاد الزراعي، نشرة الإعلة الإحصاءات الزراعية، أعداد متفرقة.

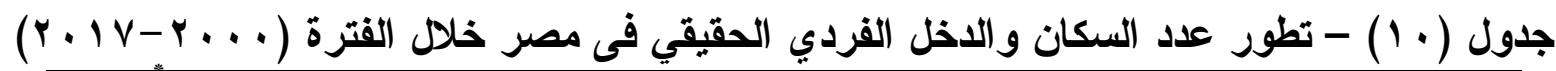

\begin{tabular}{|c|c|c|}
\hline الاخل الفردي) الحقيقي & (مليون نسمةنة) & السنة \\
\hline 11846 & 63.3 & 2000 \\
\hline 12122 & 64.7 & 2001 \\
\hline 12123 & 66.0 & 2002 \\
\hline 11667 & 67.3 & 2003 \\
\hline 11412 & 68.6 & 2004 \\
\hline 11930 & 70.0 & 2005 \\
\hline 12460 & 71.3 & 2006 \\
\hline 12042 & 72.9 & 2007 \\
\hline 10934 & 74.4 & 2008 \\
\hline 10669 & 76.1 & 2009 \\
\hline 10410 & 77.8 & 2010 \\
\hline 15328 & 79.6 & 2011 \\
\hline 18974 & 81.6 & 2012 \\
\hline 20215 & 83.7 & 2013 \\
\hline 18955 & 85.8 & 2014 \\
\hline 18128 & 88.0 & 2015 \\
\hline 18054 & 90.1 & 2016 \\
\hline 17542 & 96.3 & 2017 \\
\hline 14156 & 76.5 & المتوسط \\
\hline$\% 3.04$ & $\% 2.4$ & معدل النمو \\
\hline
\end{tabular}

* تم حساب الرقم الحقيقي بإستخدام الرقم القياسي لأسعار المستهلك لسنة أساس 100=2010 المصدر : جمعت وحسبت من :

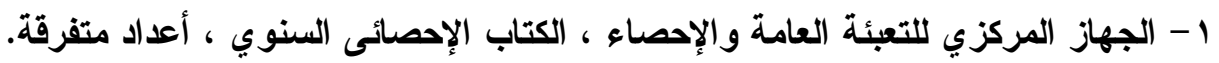

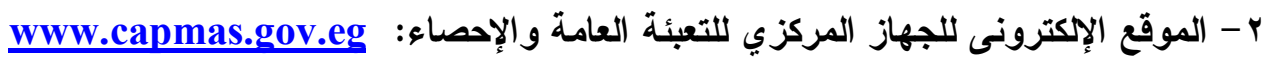

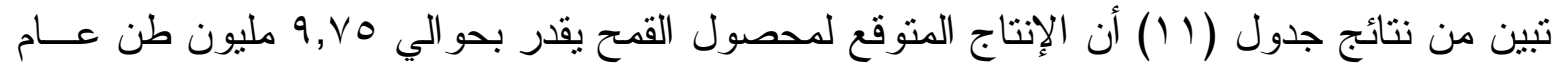

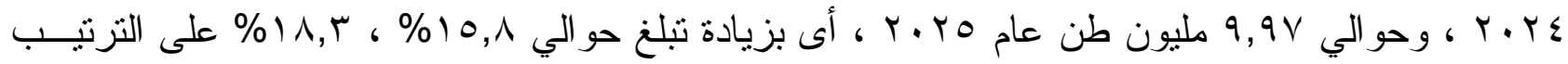

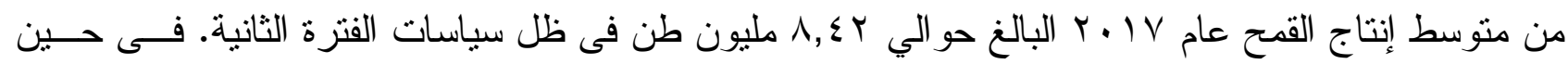




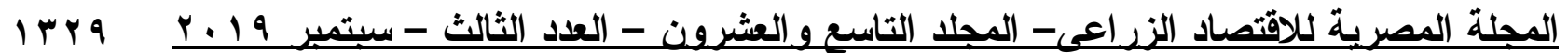

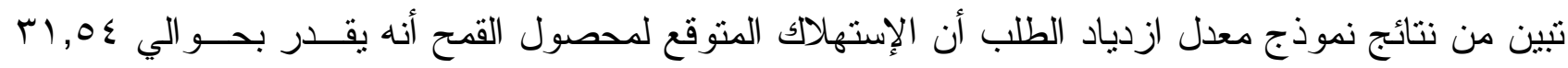

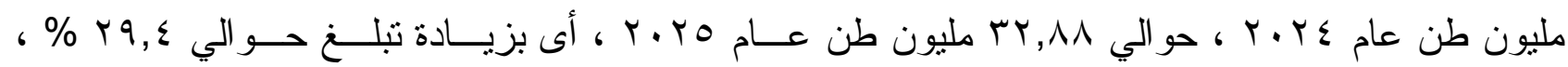

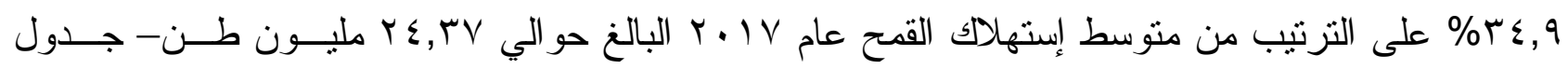

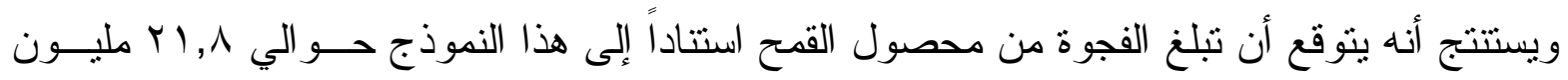

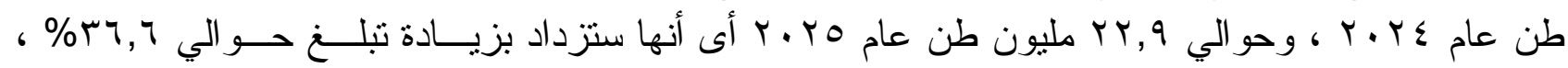

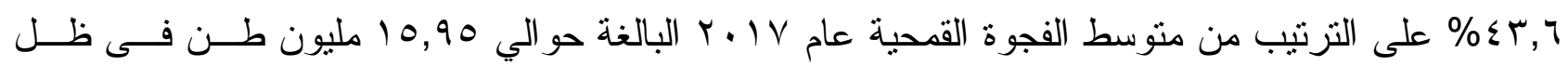

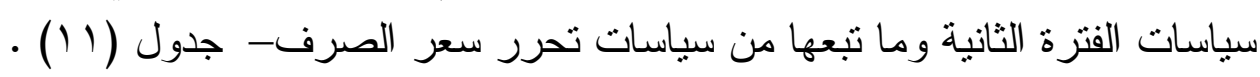

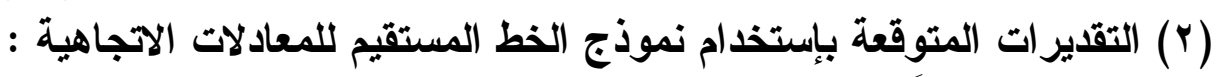

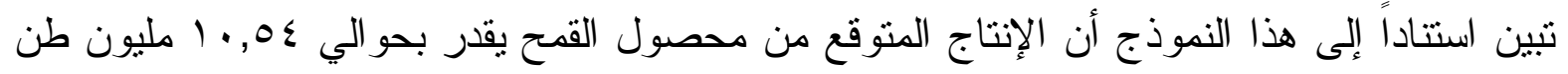

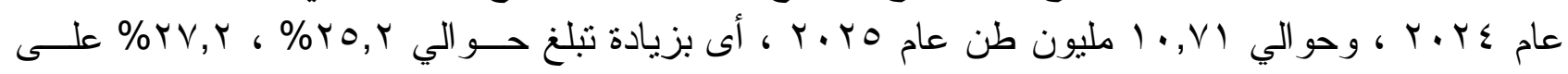

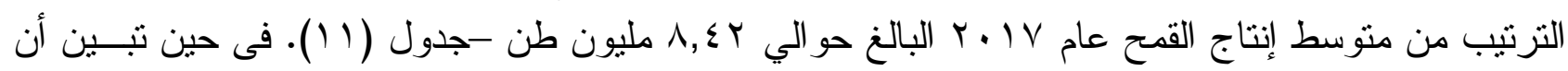

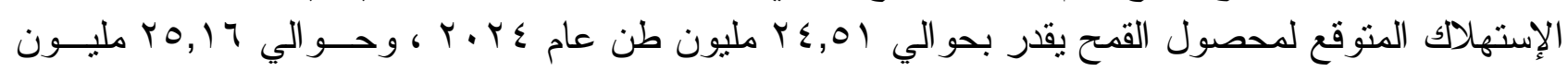

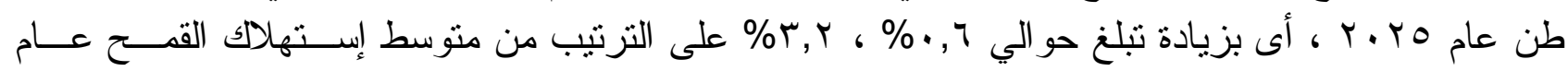

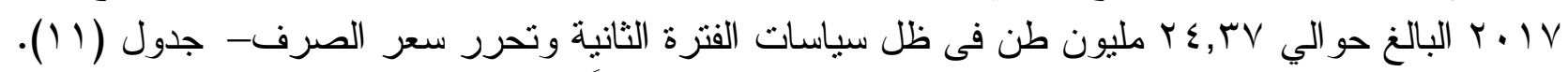

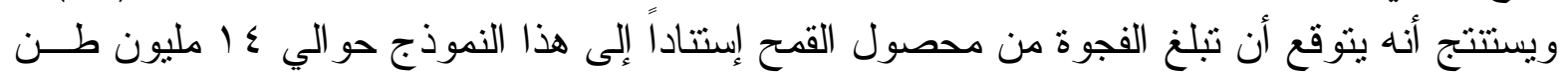

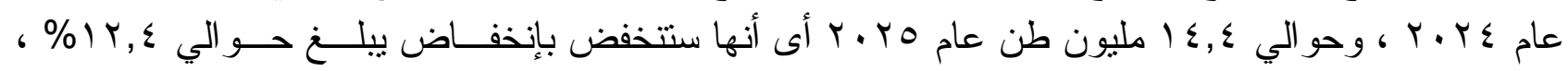

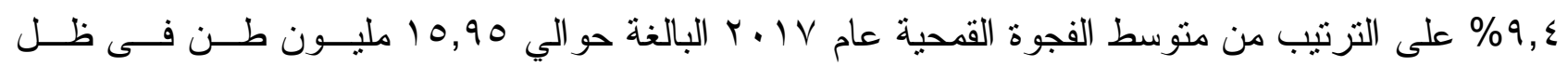

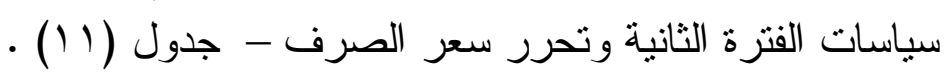

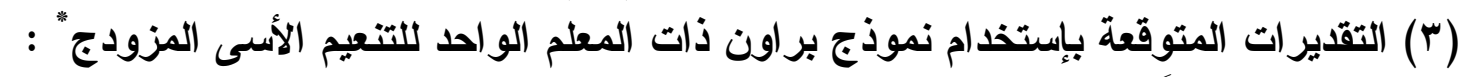

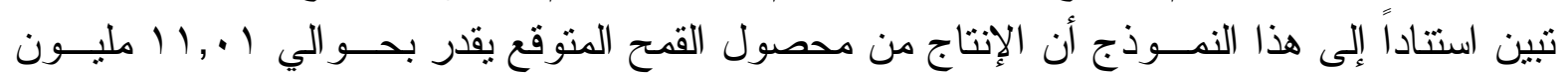

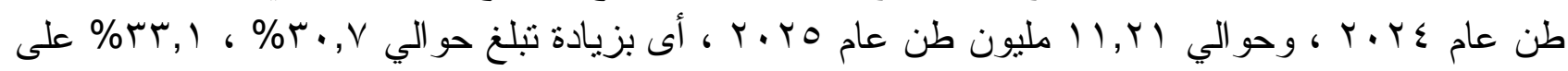

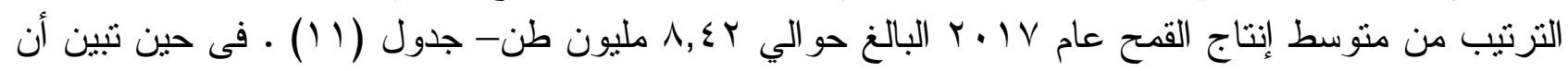

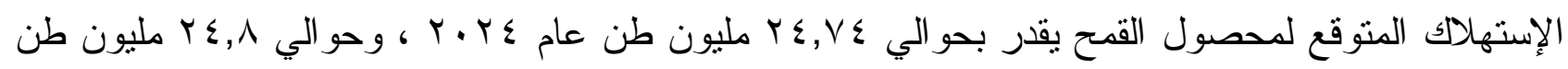

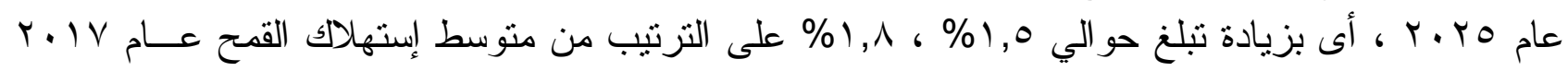

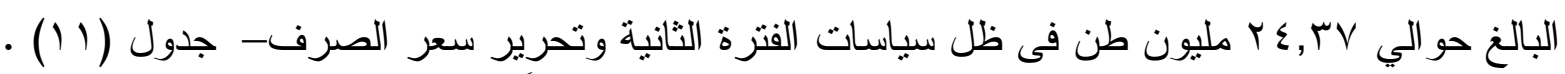

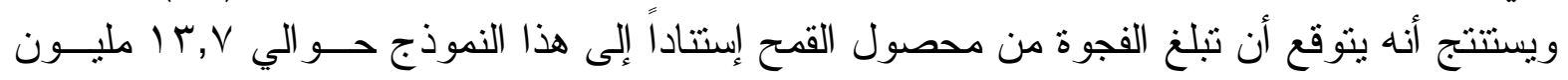

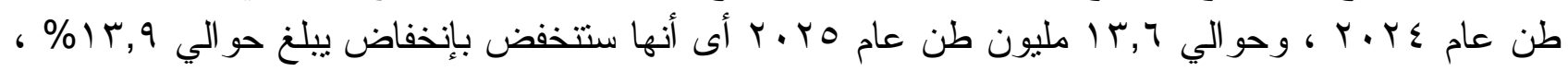

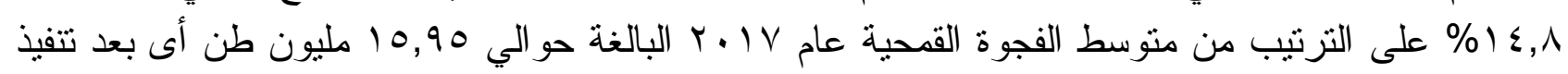

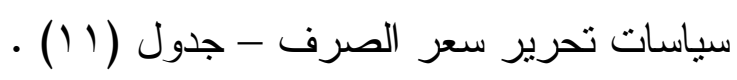

(ع) التقديرات المتوقعة بإستخدام نموذج هولت ذات المعلمين للتنعيم الأسىى المزودج:

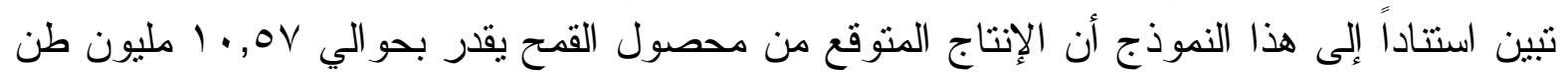

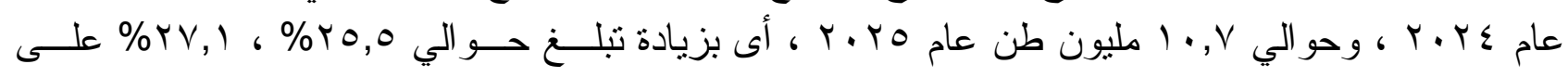

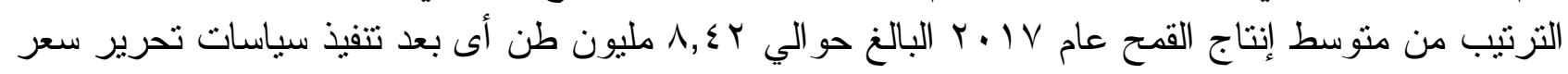

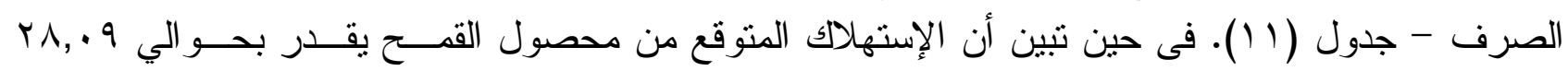


. دراسة اقتصادبة لأثر السباسات الزراعية على محصول القمح فحى مصر

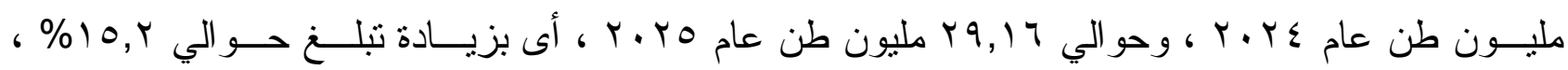

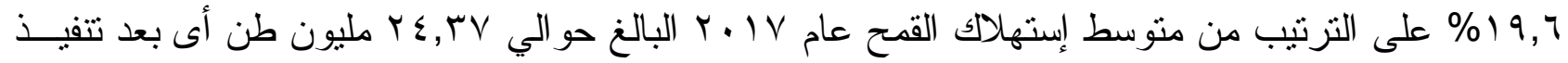

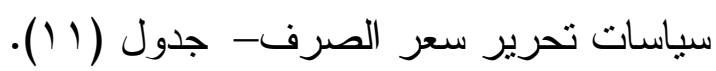

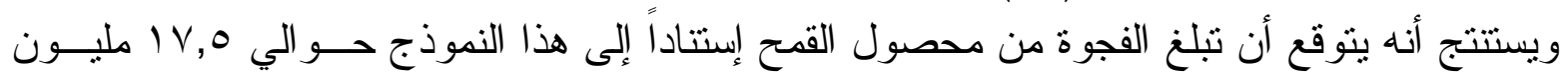

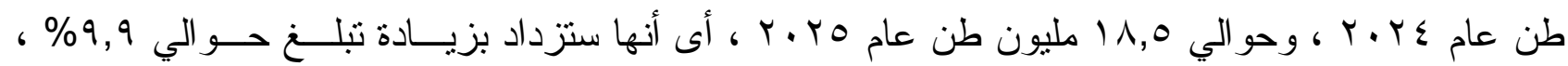

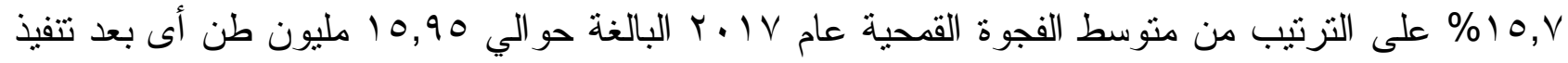

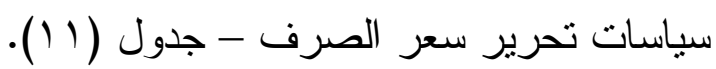

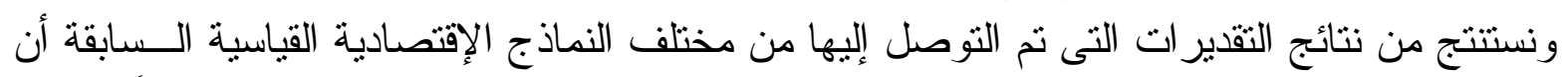

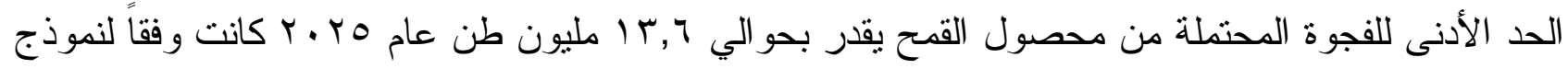

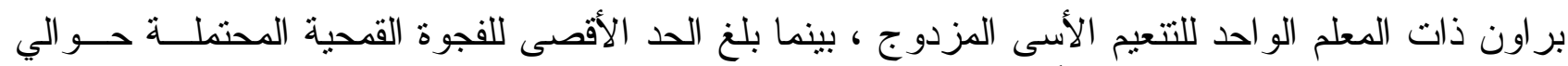
r., جدول (1 1 ) : أثر السياسات الراهنة على التقديرات المتوقعة لنماذج التتبؤ بإنتاج و إستهلاك وحجم

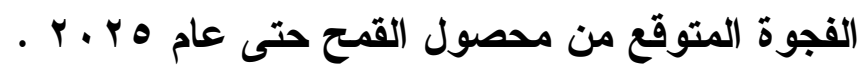

\begin{tabular}{|c|c|c|c|}
\hline (الفجوة المتوقونعة طن & 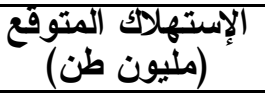 & الإتتاج المتون طن) & النموذج \\
\hline & & & نموذج إزدياد الطلب \\
\hline 18.7 & $27.87^{*}$ & 9.13 & 2021 \\
\hline 19.7 & 29.04 & 9.33 & 2022 \\
\hline 20.7 & $30.27^{*}$ & 9.54 & 2023 \\
\hline 21.8 & 31.54 & 9.75 & 2024 \\
\hline \multirow[t]{2}{*}{22.9} & 32.88 & 9.97 & 2025 \\
\hline & & & نموذج المعادلات الاتجاهية \\
\hline 12.6 & 22.57 & 10.02 & 2021 \\
\hline 13.0 & 23.22 & 10.19 & 2022 \\
\hline 13.5 & 23.87 & 10.37 & 2023 \\
\hline 14.0 & 24.51 & 10.54 & 2024 \\
\hline \multirow[t]{2}{*}{14.4} & 25.16 & 10.71 & 2025 \\
\hline & & & نموذج براون ذات المعلم ألواحد للتنعيم الأسى المزدوج \\
\hline 11.6 & 22.05 & 10.41 & 2021 \\
\hline 12.0 & 22.61 & 10.61 & 2022 \\
\hline 12.4 & 23.18 & 10.81 & 2023 \\
\hline 13.7 & 24.74 & 11.01 & 2024 \\
\hline \multirow[t]{2}{*}{13.6} & 24.80 & 11.21 & 2025 \\
\hline & & & نموذج هولت ذات المعلمين للتنعيم الاسىى المزدوج \\
\hline 14.7 & 24.88 & 10.15 & 2021 \\
\hline 15.7 & 25.95 & 10.29 & 2022 \\
\hline 16.6 & 27.02 & 10.43 & 2023 \\
\hline 17.5 & 28.09 & 10.57 & 2024 \\
\hline 18.5 & 29.16 & 10.70 & 2025 \\
\hline
\end{tabular}

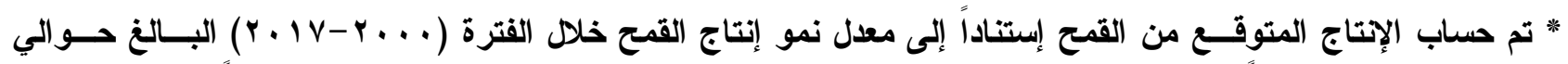

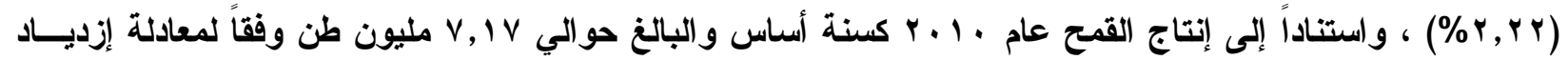

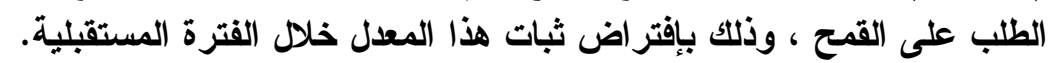

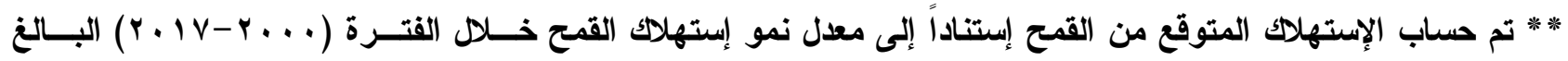

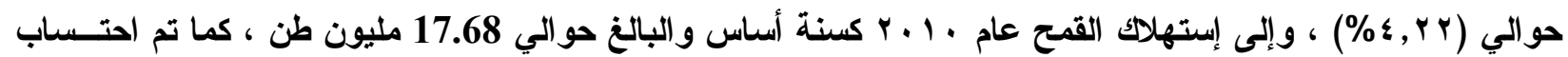

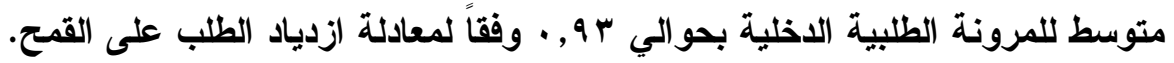
المصدر : جمعت وحسبت من جدول رقم ( ) بالبحث. 
يتتاول البحث قياس أثز السياسات الزر اعية على محصول القمح فى مصر ، من خلال در اسة إنتاج و إستهلاك وواردات و أسعار المنتج و الجملة والتجزئة من القمح، قياس مصفوفة تحليل السياسات لمحصول القمح من خلال حساب معاملات الحماية الإسمية للإنتاج، الحماية الإسمية لمسنلزمات الإنتاج ، الحماية

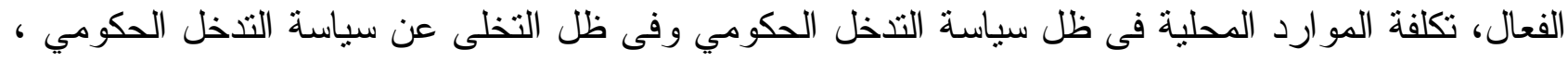

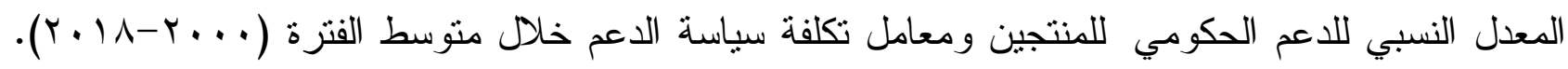
قياس نموذج التو ازن الجزئي لمحصول القمح من خلال حساب معامالت الحماية الإسمية للإنتاج وللإستهلاكك وصافى العو ائد و الخسارة الإجتماعية على المنتج و المستهلك و الآثار التوزيعية للمنتجين و المستهلكين و إجمالي الإني

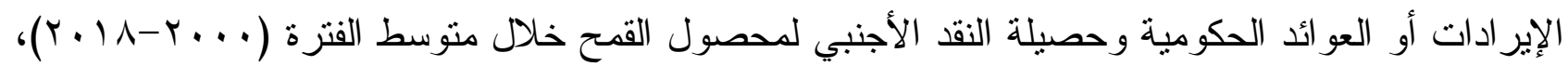

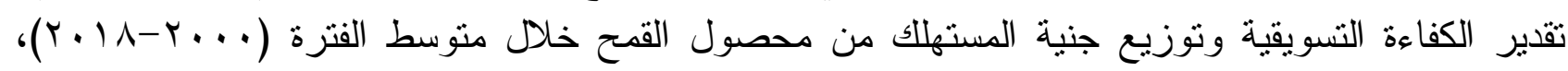
التقدير القياسي لدالة الطلب الإستهلاكى ودالة الواردات الخارجية من محصول القمح ، كما تتناول الدراسة

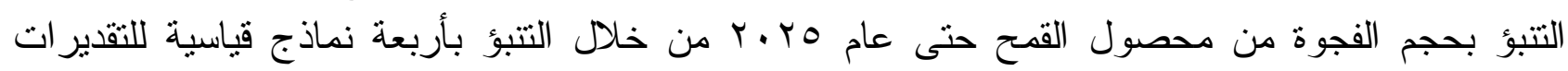

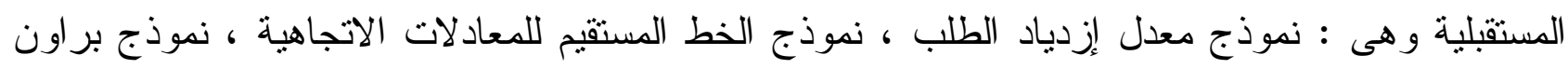

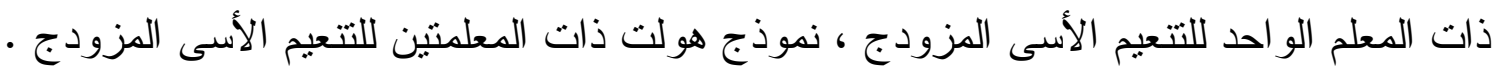

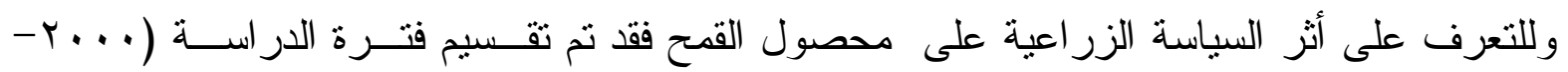

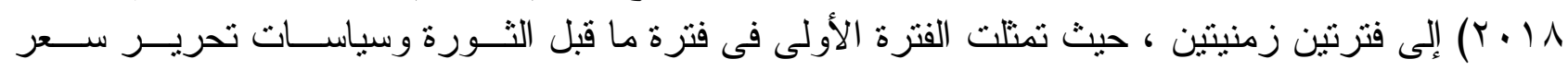

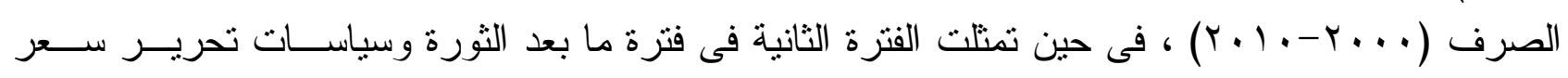

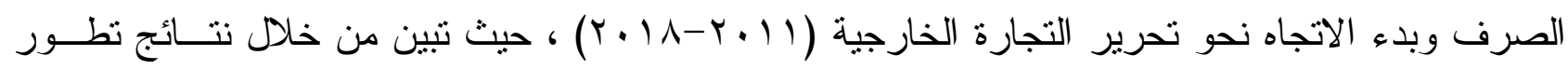

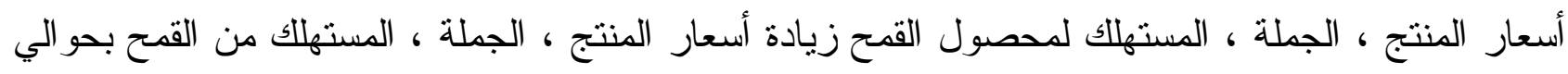

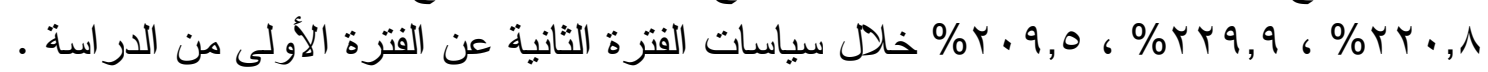

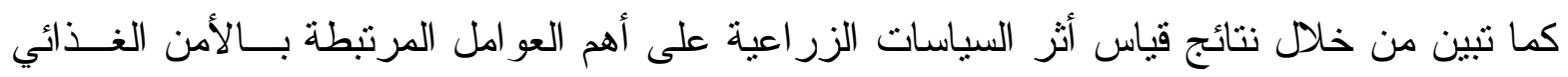

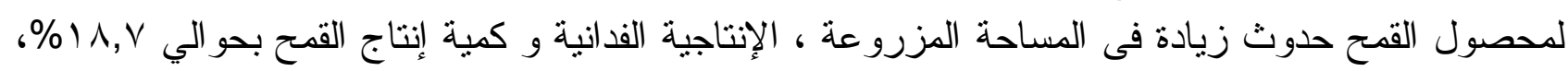

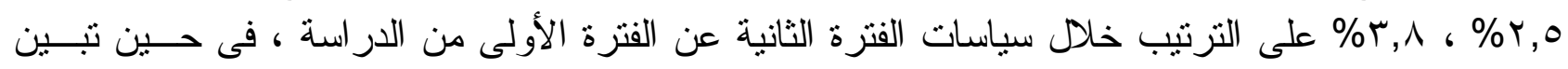

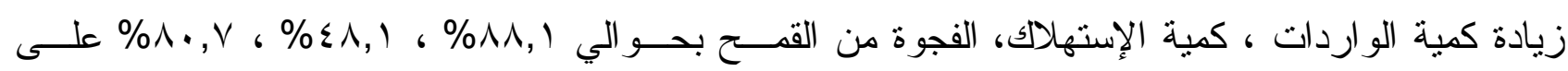

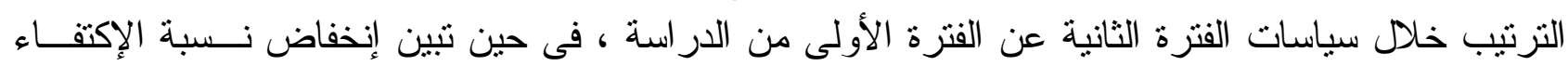

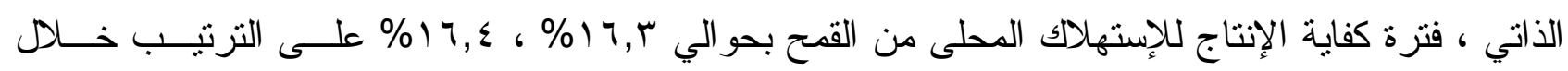

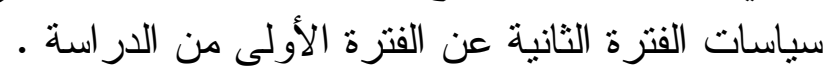

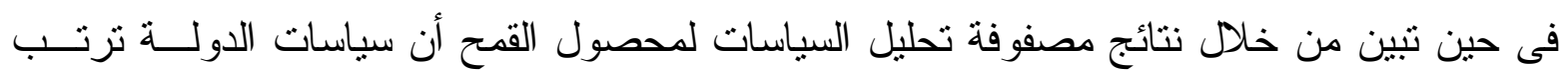

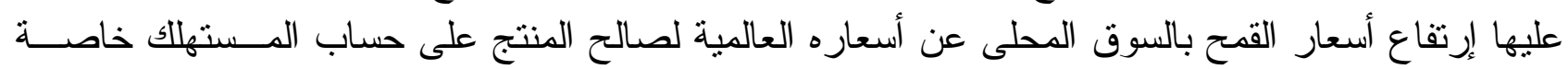

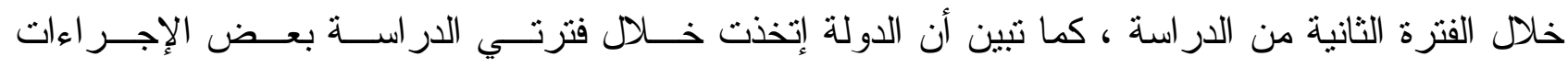

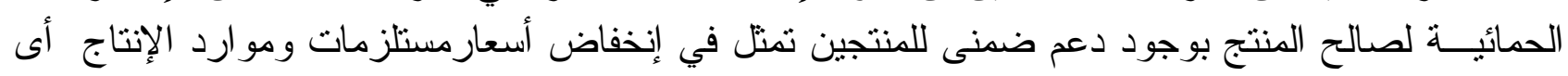

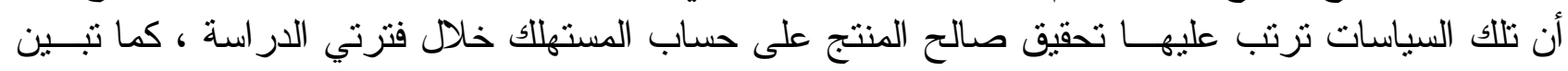

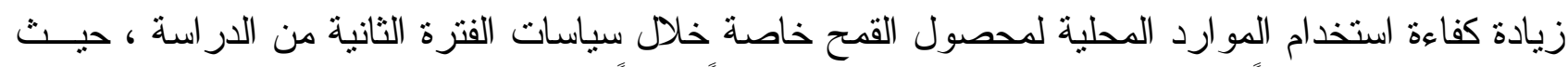

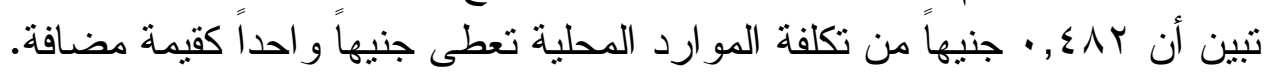

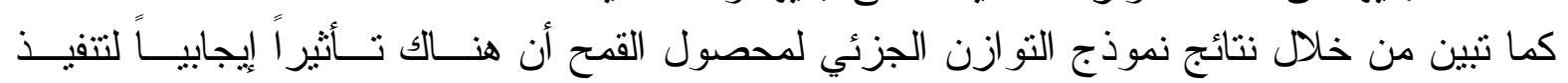

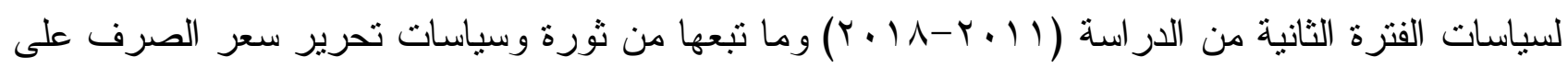

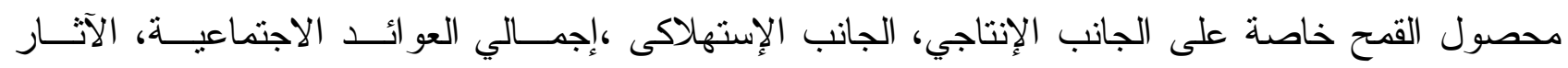




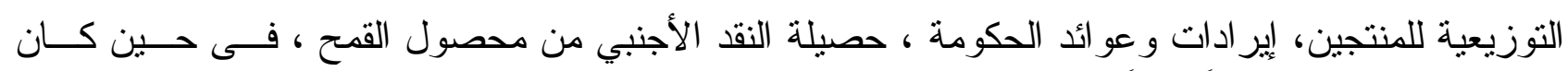

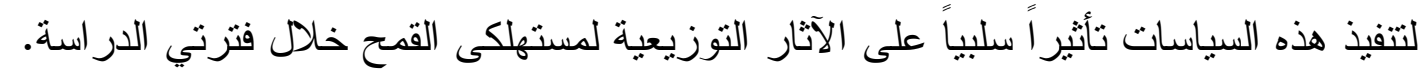

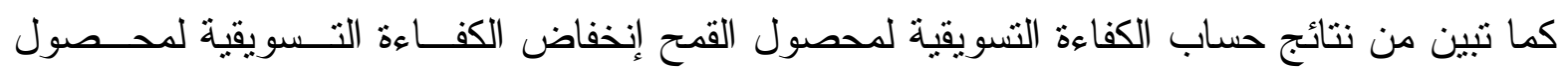

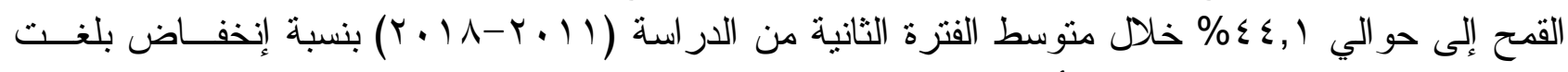

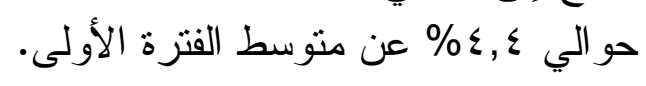
فى حين تبين من خلا التقدير القياسي لدالة إجمالي الإستهلاك من القهح وجود علاقة طردية طية بين كل

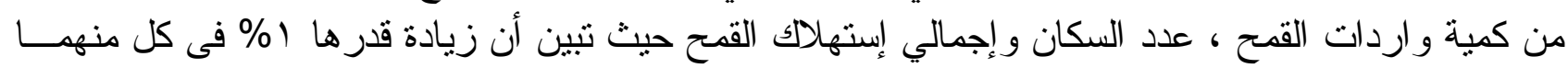

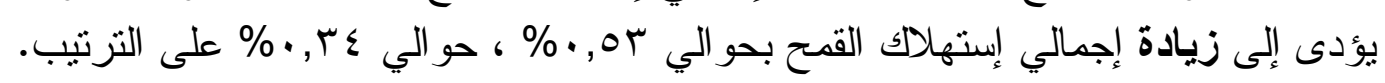

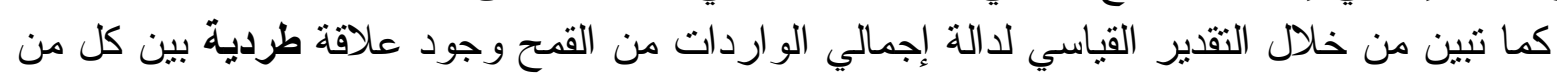

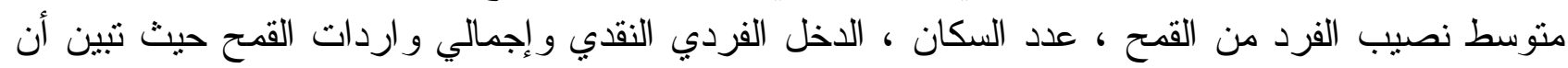

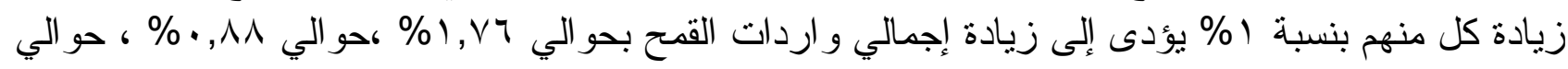

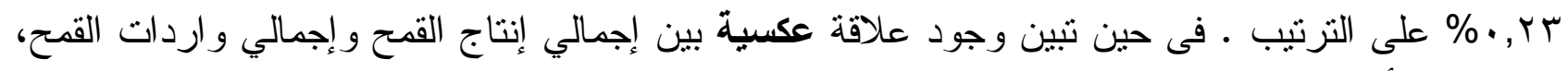

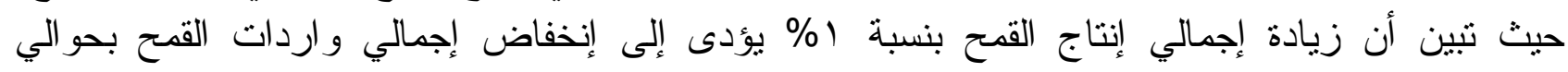
. \% . 90

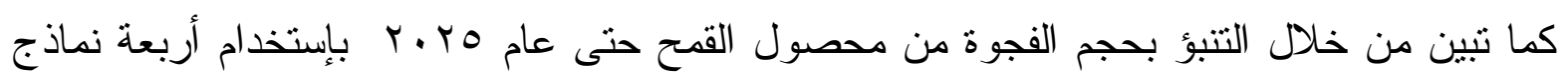
قياسية هى (معدل إزدياد الطلب ، الخط المستقيم للمعادلات الاتجاهية ، براون ذات المعلم الواحد للتتعيم

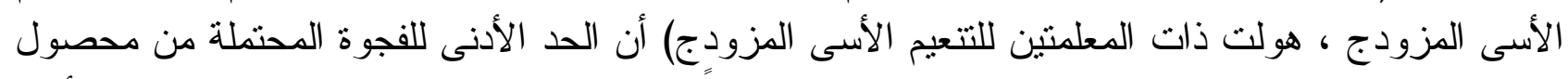

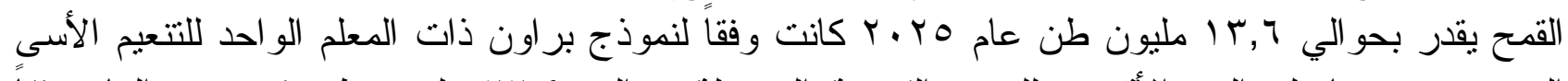

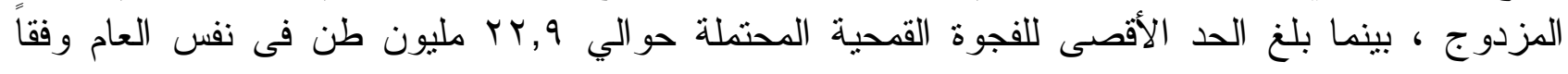
لنموذج معدل ازدياد الطلب. توصيات البحث :

ا-نرشيد الإستهالك من القمح والدقيق و نشر تجربة خلط دقيق القمح بدقيق الذرة لإنتاج الخبز •

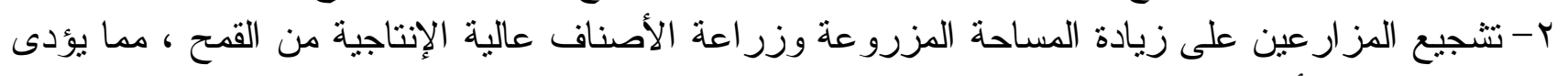

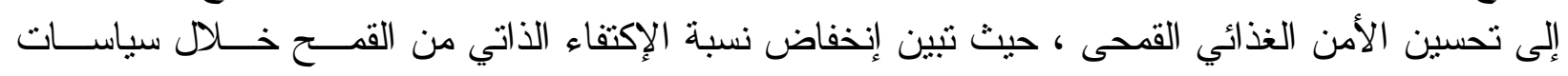

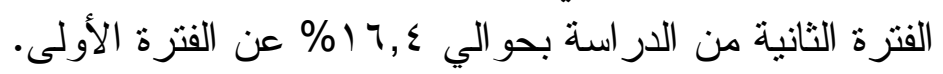

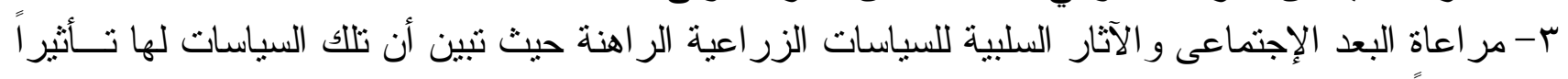

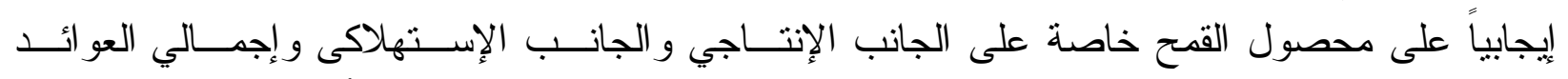

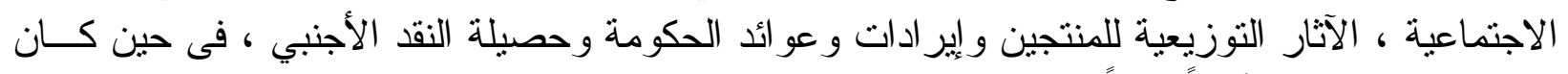

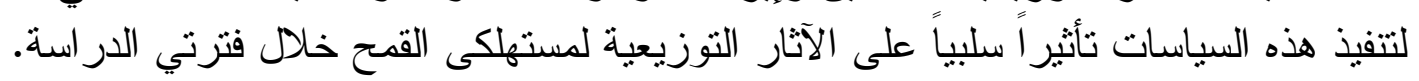

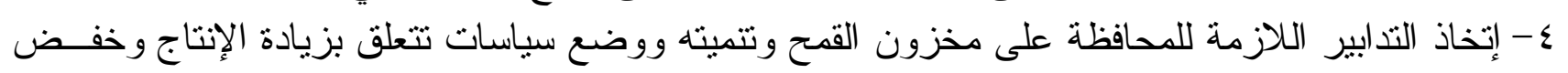

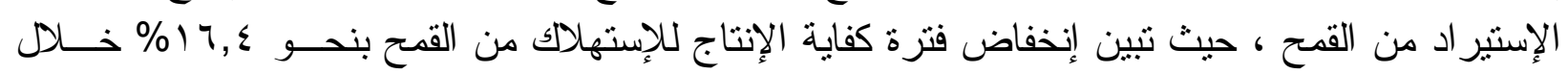
الفترة الثانية عن الفتزة الأولى، حيث تعتبر الفتزة الثانية هى فتزة سحب أكبر من المخزون الإستر اتيجى.

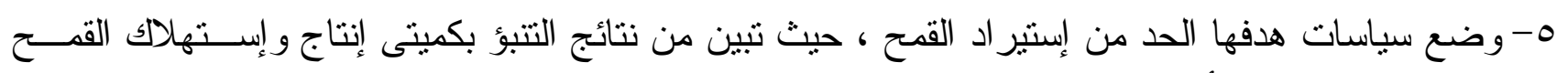

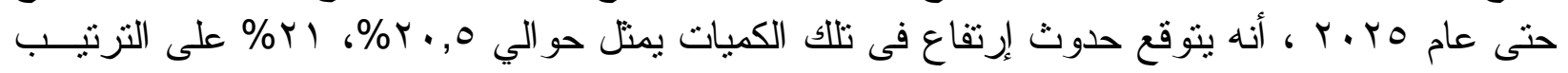

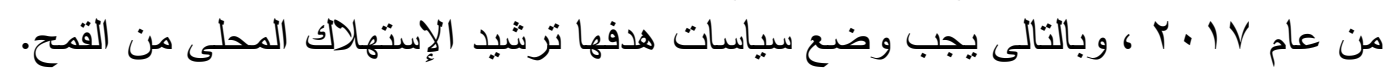

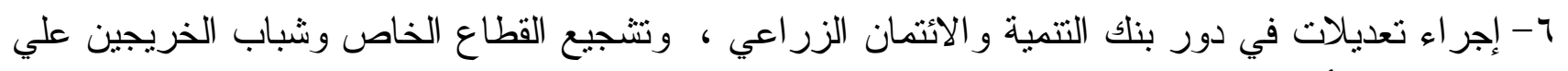

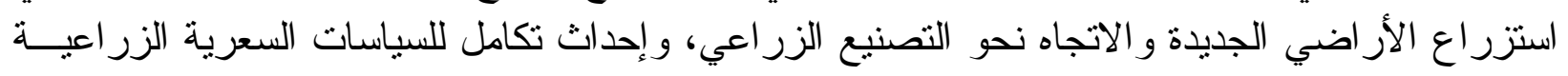

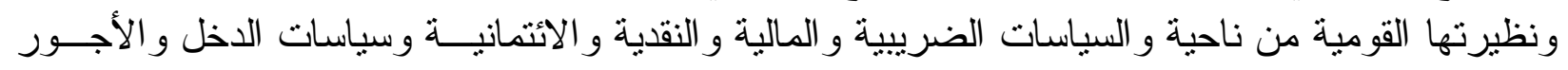




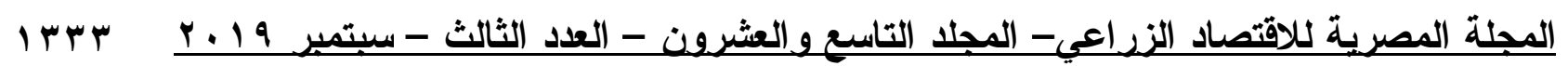

و التجارة الخارجية الزر اعية من ناحية أخري • وفى ظل تحرير أسعار المحاصيل الزر اعية وتركها لقوي

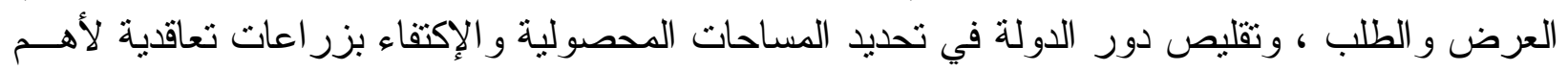

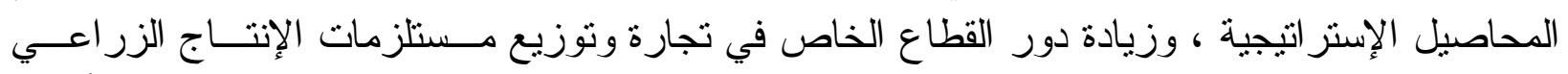

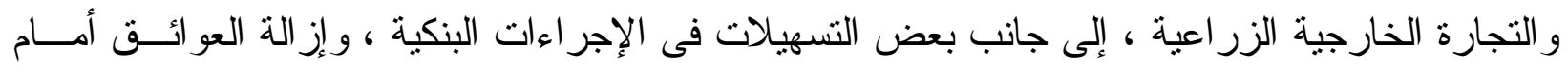

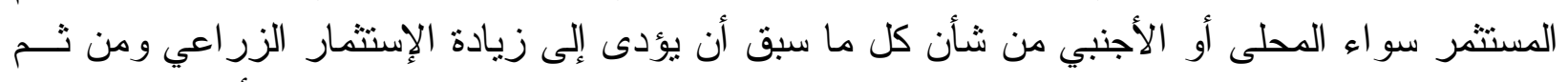

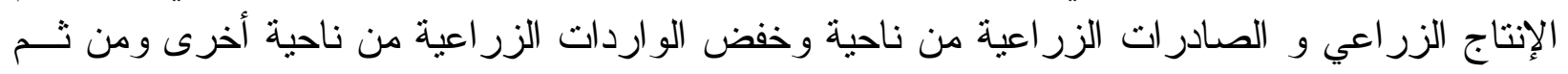

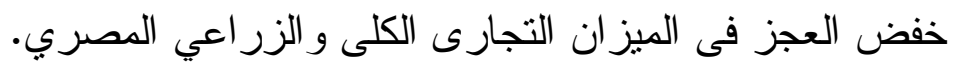
الكلمات الإسترشادية: انتاج واستهلاك القمح - مصفوفة تحليل السياسات الزراعية - نموذج التوازن الجزئي - محددات

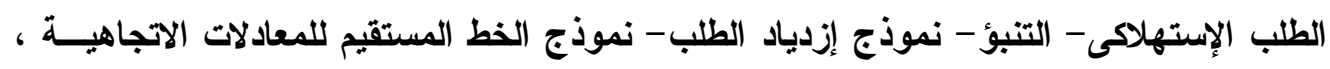

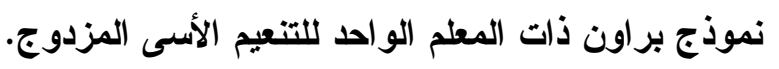

المر اجع : (المع : (المع

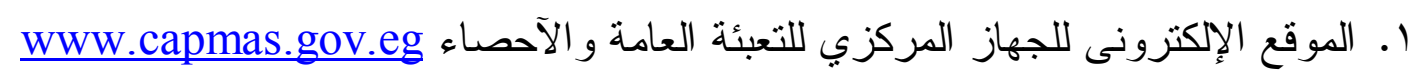

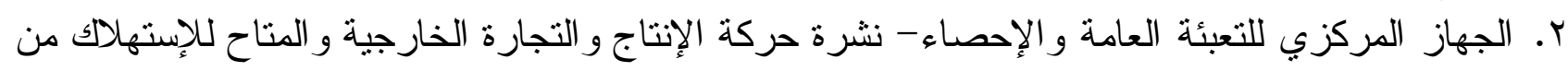

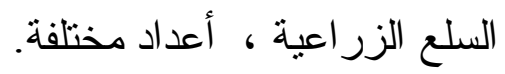

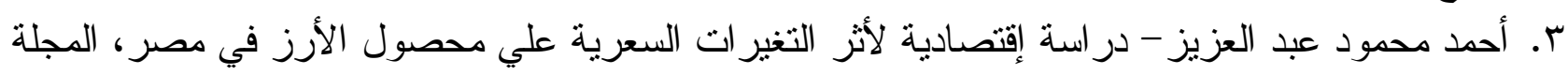

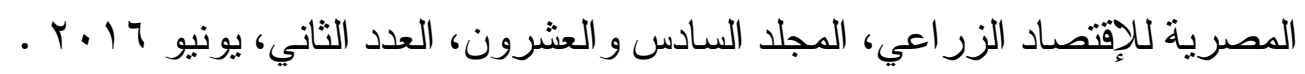

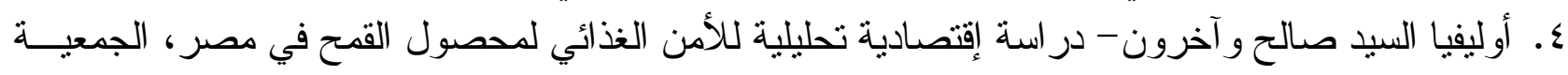
المصرية للإقتصاد الزر اعي، المؤتمر الحادي و العشرون للإقتصاديين الزر اعيين ، نادي الزر اعيين، الدقي،

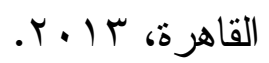

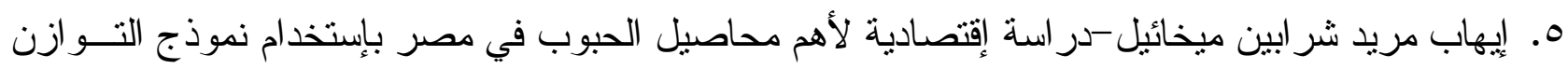

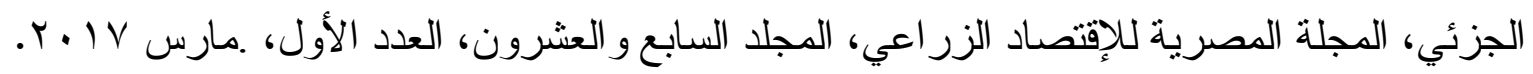

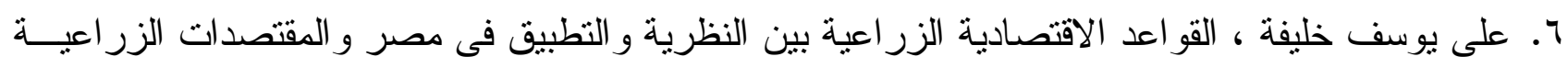

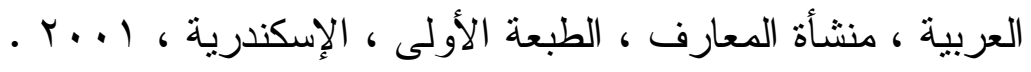

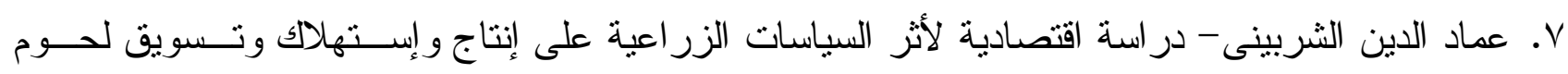

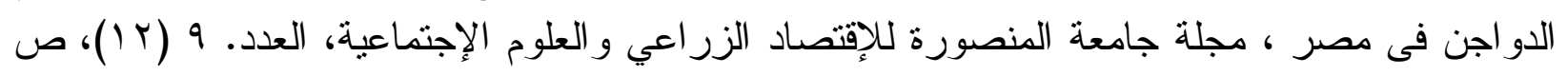
ص ص r.

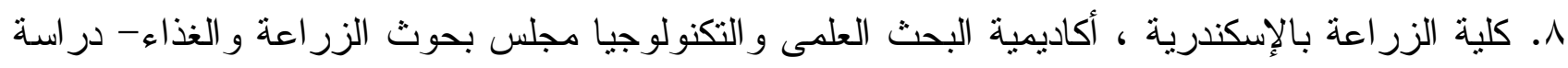

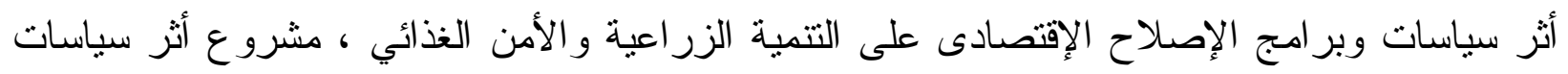

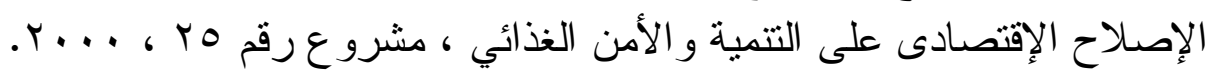

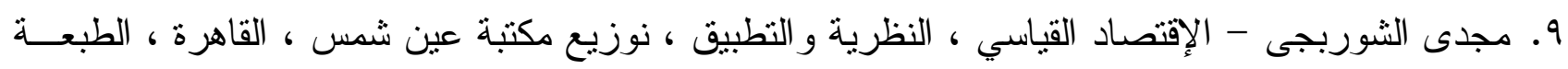

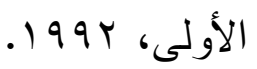

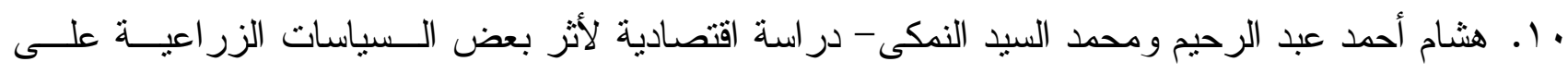

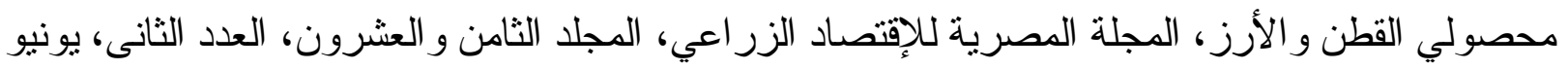
. 11

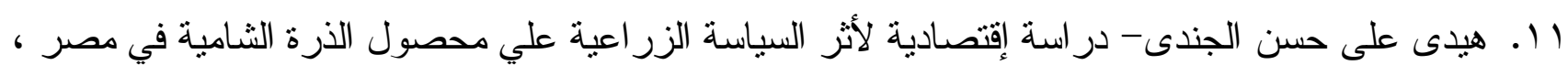

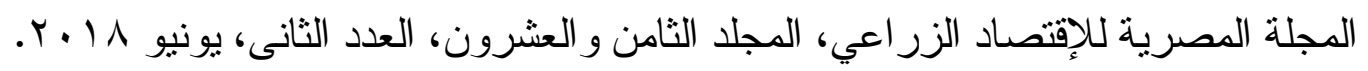


12. Henderson M. James and Richard E. quandt, Micro Economic Theory, A mathematical Approach, 3rd, International Student Edition, 1980.

13. Johnston, J., Econometric Methods, 3rd, McGraw-Hill Book Company, New York, 1984.

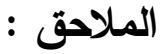

ملحق (1) :تطور التكاليف الإنتاجية لمحصول القمح موزعة إلى أجور ومستلزمات إنتاج خلال الفترة $(r+1 \Lambda-r+. \cdot)$

\begin{tabular}{|c|c|c|c|c|c|c|c|c|c|c|}
\hline الإيجار & بداليف & مصاريف & مبيات & كيماوى & سلدى ساد & تقاوى ت تمن & على & حيو عمل & عثرية & السنة \\
\hline 636 & 874 & 87 & 19 & 135 & 45 & 68 & 253 & 2 & 265 & 2000 \\
\hline 646 & 877 & 87 & 20 & 132 & 41 & 76 & 234 & 3 & 284 & 2001 \\
\hline 647 & 912 & 90 & 24 & 139 & 51 & 80 & 233 & 3 & 293 & 2002 \\
\hline 723 & 1008 & 95 & 28 & 158 & 53 & 88 & 258 & 3 & 326 & 2003 \\
\hline 799 & 1105 & 100 & 31 & 177 & 55 & 97 & 282 & 4 & 359 & 2004 \\
\hline 828 & 1153 & 105 & 36 & 188 & 37 & 115 & 292 & 4 & 376 & 2005 \\
\hline 872 & 1271 & 115 & 46 & 200 & 49 & 123 & 322 & 5 & 411 & 2006 \\
\hline 975 & 1469 & 134 & 58 & 255 & 69 & 126 & 345 & 6 & 476 & 2007 \\
\hline 1260 & 1885 & 171 & 103 & 378 & 39 & 166 & 428 & 7 & 593 & 2008 \\
\hline 1456 & 2003 & 182 & 75 & 404 & 54 & 177 & 456 & 7 & 648 & 2009 \\
\hline 1550 & 2130 & 188 & 90 & 426 & 49 & 188 & 483 & 8 & 698 & 2010 \\
\hline 1626 & 2443 & 222 & 93 & 435 & 78 & 206 & 557 & 7 & 845 & 2011 \\
\hline 1713 & 2712 & 247 & 102 & 433 & 106 & 230 & 580 & 8 & 1006 & 2012 \\
\hline 1753 & 3055 & 278 & 100 & 443 & 110 & 261 & 677 & 10 & 1176 & 2013 \\
\hline 1900 & 3371 & 306 & 132 & 469 & 113 & 285 & 737 & 0 & 1329 & 2014 \\
\hline 1987 & 3640 & 331 & 130 & 513 & 116 & 301 & 895 & 0 & 1354 & 2015 \\
\hline 3205 & 3849 & 350 & 110 & 553 & 111 & 325 & 1008 & 0 & 1392 & 2016 \\
\hline 4193 & 4798 & 440 & 151 & 758 & 257 & 350 & 1249 & 0 & 1593 & 2017 \\
\hline 5181 & 5177 & 462 & 160 & 800 & 256 & 370 & 1385 & 120 & 1625 & 2018 \\
\hline 945 & 1335 & 123 & 48 & 236 & 49 & 119 & 326 & 5 & 430 & $\begin{array}{c}\text { متوسط } \\
\text { (2010-2000) }\end{array}$ \\
\hline 2695 & 3631 & 330 & 122 & 551 & 143 & 291 & 886 & 18 & 1290 & متوسط $\begin{array}{c}\text { متو-2018) } \\
\text { (2018) }\end{array}$ \\
\hline 1682 & 2302 & 210 & 79 & 368 & 89 & 191 & 562 & 10 & 792 & المتوسط العام \\
\hline
\end{tabular}

المصدر : جمعت وحسبت من : وزارة الزراعة وإستصلاح الأراضى ، الإدارة المركزيسة للاقتــصاد الزراعسي ، نــشرة الإحصاءات الزراعية، أعداد متفرقة. 


\section{An Economic Study of the Impact of Agricultural Policies on Wheat}

\section{Dr. Rasha Saleh Mansour \\ Researcher- Agricultural Economics Research Institute (AERI) \\ Summary}

The research deals with measuring the impact of agricultural policies for wheat in Egypt, through study of production, consumption, imports, prices of wheat, wholesale and retail, measurement of policy matrix analysis, calculation of nominal protection factors for production, nominal protection of input, effective protection, cost of domestic resources, proportion of government subsidies to producers, support cost policy coefficient during the average period (2000-2018). Analysis of the partial equilibrium model of wheat, calculation of nominal protection factors, effective, net social returns and loss, on producer and consumer, distributional effects of producers and consumers, total government revenues, foreign exchange earnings for the wheat during the average period (2000-2018). It also deals with estimating the marketing efficiency, distribution of consumer Egyptian pound for the wheat during the average period (2000-2018), estimating the consumption demand function, external import function of wheat, forecasting the gap of wheat until 2025, through the four standard models: Increase in demand, straight line model of trend equations, Braun singleparameter model for the double-sided exponential smoothing, Holt double-sided model for the double-sided exponential smoothing.

In order to identify the impact of agricultural policy on the wheat, the study period (2000-2018) was divided into two time periods, the first period is in the period before the revolution and exchange rate liberalization policies (2000-2010), while the second period is in the post-revolution period and exchange rate liberalization policies (2011-2018), while the results of development of prices shows the increasing in the prices of producer, wholesale, consumer of wheat by about $220.8 \%$, $229.9 \%, 209.5 \%$ during the period policies Second about the first period of study.

\section{Research Recommendations:}

1- Rationalize the consumption of wheat and flour; spread the experiment of mixing wheat flour with corn flour to produce bread.

2- Encouraging farmers to increase the cultivated area and cultivate high-yielding varieties, which leads to improved food security of wheat, where the self- 
sufficiency rate during the second period of the study showed a decrease of about $16.4 \%$ from the first period.

3- Taking into account the social dimension, the negative effects of agricultural policies, where it was found that these policies have a positive impact on wheat crop, especially on the production side, consumption, total social returns, distributional effects of producers, government revenues and foreign exchange earnings, while the implementation of these policies, Negative impact on the distributional effects of wheat consumers during the two study periods.

4- The necessity to take the necessary measures to maintain the wheat stockpile and develop policies related to increasing production and decreasing the import of wheat, where the period of production adequacy for consumption decreased by about $16.4 \%$ during the second period from the first period, where shows the second period is a period of greater withdraw from the strategic stock.

5- Developing policies aimed at decreasing the import of wheat, where the results of the forecast in 2025 shows it is expected that there will be an increase in the production and consumption of wheat, representing about $20.5 \%$ and $21 \%$ respectively from 2018, therefore the target of policies will be rationalize consumption of wheat . 